\title{
COM A PALAVRA OS MESTRES GRIÔS
}

Graduada em História pela Universidade Federal de Viçosa (2007), com Especialização em Gestão Cultural e Organização de Eventos. Atua com elaboração e gestão de projetos na área da Memória e Cultura, produção cultural de eventos, shows, exposições, seminários entre outros. Pesquisa orientada pelo Prof. Dr. Dennis de Oliveira.

\section{Resumo}

O seguinte artigo propõe-se a uma reflexão sobre o processo de interação entre os mestres de Tradição Oral (e seus conhecimentos) e a escola - lugar por excelência da educação formal. Esta reflexão tem por base os depoimentos de Mestres de tradição oral integrantes do Programa Ação Griô Nacional. Os depoimentos são analisados buscando perceber o processo de interação entre conhecimento tradicional de tradição oral no espaço da educação formal fundamentados pelos conceitos de cultura hegemônica, cultura subalterna e cultura popular.

Palavras-chave: Cultura oral; aprendizado; ensino; conhecimento; Griô

\section{Resumen}

El artículo propone una reflexión acerca del proceso de interacción entre los maestros de Tradición Oral (y sus conocimientos) y la escuela - lugar por excelencia de la educación formal. Esta reflexión tiene como base los testimonios de Maestros de tradición oral que hicieron parte del Programa Ação Griô Nacional. Los testimonios son analizados tratando de percibir el proceso de interacción entre conocimientos tradicionales orales y educación formal, basandose en los conceptos de cultura hegemônica, cultura subalterna y cultura popular.

Palabras clave: Oralidad; aprendizado; ensino; conocimiento; Griô

\section{Abstract}

The article proposes a reflection on the process of interaction between masters of Oral Tradition (and theirs knowledge) and the school - the place par excellence of formal education. This reflection is based on the depositions of oral tradition masters that were part of the Programa Ação Griô Nacional. The depositions were analyzed trying to perceive the process of interaction between oral traditional knowledge and formal education, based on the concepts of hegemonic culture, subaltern culture and popular culture.

Keywords: Oral culture; learning; teaching; knowledge; Griô 


\begin{abstract}
"Antigamente tinha um lugarzinho e tinha um mestre ali, curandeiro, um mestre alfaiate, um mestre carpinteiro, um mestre capoeirão. A gente aprende na capoeira que é a vida que faz um mestre, não um diploma de doutor, é a vida. E parece ser um processo tão natural o surgimento dessas pessoas, desses mestres, que façam por paixão alguma arte, e na verdade é mais demorado o surgimento deles, é o tempo de muitas experiências. Bem mais rápido é o surgimento do mestre acadêmico." (CARVALHO, 2007: 32) - Entrevista concedida ao Museu da Pessoa em 07/10/2007)
\end{abstract}

\title{
Introdução
}

A Ação Griô Nacional, faz parte do Programa Cultura Viva do Ministério da Cultura e tem como missão a valorização da cultura popular brasileira através da tradição oral. A missão é semear educação e tradição oral fortalecendo a identidade das crianças, adolescentes e jovens brasileiros. Reinventar a integração entre o velho e o novo num presente pleno de ancestralidade e identidade na educação para a celebração da vida. A integração das idades e valorização da cultura local são estratégias fundamentais para a reconstrução do fio da história e fortalecimento da identidade das crianças, adolescentes e jovens buscando interromper o ciclo intergeracional da pobreza. A idéia é inovadora porque propõe incorporar à esfera da educação, da política e da economia da comunidade, a força e o poder da tradição oral.

Com o intuito de refletir sobre a Ação Griô, e mais especificamente, sobre como se dá este processo de levar o conhecimento transmitido oralmente para o âmbito da escola, buscamos conhecer a realidade vivenciada pelos mestres neste projeto, sob seu próprio ponto de vista.

A seguinte pesquisa se baseia então, na análise de depoimentos dos mestres de tradição oral sobre a experiência de levar seu conhecimento a escola. Antes desta análise, realizamos uma apresentação sobre os conceitos de cultura popular, hegemonia, e cultura subalterna. À apresentação, segue uma breve descrição da Ação Griô Nacional, seus elementos e necessidades.

Para coleta e análise dos depoimentos utilizamos como metodologia a história oral. A fonte principal utilizada são os depoimentos registrados ao longo do ano de 2007 pelo Projeto Memória dos Brasileiros, realizado pelo Instituto Museu da Pessoa, do qual tivemos o prazer de participar. O Projeto Memória dos Brasileiros acompanhou quatro Encontros Regionais da Ação Griô Nacional, registrando a história de 24 Mestres Griôs. As histórias de vida se mostraram tão emocionantes que despertaram a idéia desta analise da vivência dos Mestres Griôs na rede Ação Griô Nacional.

Nos debruçamos então, sobre cinco depoimentos de Mestres de localidades diferenciadas, com as seguintes perguntas em mente: 
- Qual a importância para o mestre griô em levar seu conhecimento a escola?

- $\quad$ Como foi o processo de adaptação?

A memória apresenta-se como fonte histórica peculiar, uma vez que, em sua estreita relação com a história, tanto a memória coletiva quanto a individual se impregnam de uma historicidade cuja dimensão é passível de ser interpretada, sobretudo no diálogo entre passado e presente. Sem dúvida, não se trata de construir um quadro real ou verdadeiro do passado a partir desses relatos, mas de pensar questões, através dos atores históricos do processo. Portanto a história oral revela mais sobre sentimentos e significados do que sobre eventos. Seu conteúdo é o cotidiano, a cultura material.

O uso desta metodologia se faz então pertinente numa análise, por meio da vivência de mestres que, revelando o seu cotidiano no projeto, apontam sucessos e dificuldades encontradas no processo, sobre a interação entre cultura oficial e cultura popular em busca de formas de torná-la cada vez melhor, no sentido de fortalecer a ambas.

\section{Cultura popular x Cultura subalterna}

Neste item, pretende-se apresentar a fundamentação teórica utilizada na concepção e execução do presente trabalho de pesquisa. Essa tarefa é de fundamental importância para que a compreensão da apresentação da Ação Griô Nacional e da análise das entrevistas, esteja pautada dentro da perspectiva dos estudos culturais baseados na teoria cultural gramsciniana. Para tal, discutimos a seguir: os conceitos de cultura popular, hegemônica e subalterna.

O primeiro ponto a ser ressaltado, em uma análise das relações estabelecidas no processo de inserção da tradição oral na escola, tal como nos propomos a fazer neste artigo em relação a Ação Griô Nacional, refere-se à necessidade de um conceito mais preciso do que vem sendo utilizado para caracterizar as manifestações culturais transmitidas oralmente: cultura popular.

Concorda-se, neste ponto, com Ferreira (2005, p. 06) quando ela diz que a consideração e conceituação destas realidades por meio do termo "cultura popular" limitam a compreensão da complexidade contida nesta realidade, e propõe que se alcance pela abordagem a partir do conceito gramsciano de "cultura subalterna".

Cabe ressaltar, contudo, que não se nega aqui o conceito de "cultura popular", mas que, considerando-a não apenas como "popular", mas também como "subalter- 
na", pode-se alcançar outros elementos fundamentais para a compreensão da reprodução e transmissão dessa cultura, no caso estudado, a cultura de tradição oral.

Seguindo de acordo com Ferreira em sua interpretação acerca da teoria gramsciana, assume-se a compreensão do conceito de "cultura" sob uma perspectiva dinâmica e historicista, como "um processo que conserva e renova-se permanentemente somente na prática social" (FERREIRA, 2005, p. 07). Esta compreensão questiona a idéia de que a cultura é apenas o que está abrangido pelas atividades intelectuais e o processo de seu desenvolvimento, sobretudo àquelas atividades ligadas ao campo da arte e da educação. Em poucas palavras, trata-se de mostrar que a cultura está em toda e qualquer prática social, e não apenas naquelas da classe dominante.

Para compreender essa conceituação da "cultura" deve-se agregar a ela a reflexão de Gramsci sobre o conceito de "hegemonia". Segundo Chauí (1987, p. 21): "pode-se dizer que, para Gramsci, a hegemonia é a cultura numa sociedade de classes. Hegemonia não é um 'sistema: é um complexo de experiências, relações e atividades cujos limites estão fixados e interiorizados".

Mas, como ela mesma ressalta ao evocar a fala de Raymond Williams,

"uma hegemonia viva é sempre um processo. (...). Deve ser continuamente renovada, recriada,
defendida e modificada e é continuamente resistida, limitada, alterada, desafiada por pressões
que não são suas. Nesse sentido devemos acrescentar ao conceito de hegemonia os conceitos de
contra-hegemonia e hegemonia alternativa" (WILLIAMS apud CHAUÍ: 22)

Assim considera-se que a cultura popular é aquela própria das classes subalternas, definição essa que difere do conceito de "classes exploradas", na medida em que o termo subalterno refere-se não apenas à determinação econômica pelo lugar que a classe ocupa na estrutura produtiva, mas também à dominação cultural, o que é dizer, ao seu lugar no âmbito da hegemonia.

O mais interessante nestas considerações sobre a hegemonia e a contra-hegemonia é a idéia de que a cultura popular não é uma totalidade orgânica e fechada sobre si mesma, ou seja, uma "outra cultura" que se reproduz ao fundo de uma cultura dominante. Pelo contrário, trata-se da forma de expressão das classes subalternas em sua relação com as classes dominantes. Para Chauí, a cultura popular deve ser tomada como a expressão dos dominados,

"buscando as formas pelas quais a cultura dominante é aceita, interiorizada, reproduzida e transformada, negada e afastada, implícita ou explicitamente pelos dominados. (...) como manifestação diferenciada que se realiza no interior de uma sociedade que é a mesma para todos, mas dotada de sentidos e finalidades diferentes para cada uma das classes sociais". (CHAUÍ, 1987: 22) 
Aqui evocamos esses teóricos para ressaltar a necessidade de se considerar a dimensão de embate entre hegemonia e contra-hegemonia existente num trabalho como o realizado pela Ação Griô Nacional, que traz para o âmbito da cultura hegemônica - no espaço da escola - o saber dos Mestres de cultura popular. Reconhecemos nesta ação um lócus privilegiado para a análise da aceitação, negação e transformação operadas pelas classes subalternas em sua relação direta com a cultura hegemônica, e buscamos os indícios destas operações nos depoimentos de alguns mestres sobre sua inserção na ação que é apresentado a seguir.

\section{Ação Griô Nacional}

Com o objetivo de dar continuidade a pesquisa, definiremos a seguir quem são os mestres griôs, de onde surge tal denominação e o que representam dentro da Ação Griô Nacional. Uma vez que o foco do trabalho é analisar a partir dos pontos de vista destes mestres de cultura popular o processo de sua inserção no âmbito da educação formal, a escola. O que é ser um Mestre Griô? É a primeira pergunta que procuraremos responder neste item.

A palavra griot é de origem francesa e denota a princípio os genealogistas, contadores de história, músicos e poetas populares dos grupos étnicos africanos Bambaras e Fulas na região do Mali. São etnias que transmitem sua cultura através da tradição oral onde a palavra tem poder e significado divino, possuindo compromisso com a verdade e a ancestralidade. São homens e mulheres que possuem uma imagem social e política determinante no funcionamento das sociedades do noroeste da África. O significado do griô remete a uma sociedade baseada no diálogo entre os indivíduos e na comunicação entre as comunidades ou grupos étnicos.

No âmbito da Ação Griô Nacional, o conceito do Mestre Griô foi sistematizado a partir dos rituais de vínculo e aprendizagem vivenciados no município de Lençóis; localizado no estado da Bahia; e em diversos cantos do país. O perfil do Mestre Griô é utilizado como base para a proposição de políticas educativas e culturais de tradição oral. Tradição esta presente na cultura popular brasileira vivenciada em diversas regiões, mas na grande maioria dos casos negligenciada pela cultura hegemônica, por exemplo, em espaços como a escola.

São pessoas como a rezadeira, o pajé, o pai e a mãe de santo, o tecelão, o construtor de instrumentos musicais ou brinquedos; que possuem uma experiência e papel importante em sua comunidade, mas que por carregarem uma cultura que "é construída no espaço e no tempo da cotidianidade das classes subalternas" (FERREIRA, 2005: P.09), enfrentam dificuldades no processo de transmissão e reprodução de seu saber no contexto da sociedade atual. 
Assim o mestre deve possuir em seu perfil, de acordo com a pedagogia griô, as seguintes características: ser reconhecido nas comunidades como líderes espirituais, com a sabedoria da cura ou de iniciação para a vida; conhecedores/as e fazedores/as de conhecimentos, iniciados ou iniciadores/as de um ramo tradicional em artes e ofícios diversos relacionados às ciências da vida; possuir uma história de vida de tradição oral; aquele que se identifique com a figura do/a sábio/a e do/a mestre; ter a idade mínima de 60 anos. (PACHECO, 2006)

Após essa breve apresentação das características de um Mestre Griô, nos falta esclarecer, antes de passar à análise aos depoimentos, qual a função de um mestre dentro da rede Ação Griô Nacional. Ou seja, como se dá o processo de inclusão da tradição oral no âmbito da educação formal e oficializada.

Para explicar a função do mestre é de suma importância apresentar também o papel do griô aprendiz e do griô de tradição oral. Para tanto realizaremos observações coletadas no Edital de Divulgação de Bolsas de Incentivo Griô n. 02 lançado pelo Ministério da Cultura - Secretaria de Programas e Projetos em junho de 2008 (MINISTÉRIO DA CULTURA, 2008).

Com o objetivo de preservar e valorizar a tradição oral do Brasil para o fortalecimento da identidade das crianças, adolescentes e jovens vinculados à sua ancestralidade, a Ação Griô atende às instituições que atuam com propostas educacionais relativas à esta preservação e valorização, com o repasse de bolsas de trabalho, pelo período de um ano, para Griôs e/ou Mestres de Tradição Oral que estejam envolvidos em Projetos Pedagógicos dos Pontos de Cultura e da Ação Griô - Cultura Viva, em parceria com escolas e/ou universidades públicas.

Os projetos podem ser elaborados e apresentados pela rede de Pontos de Cultura através de um griô aprendiz - artista, educador, pesquisador, caminhante; que deve revitalizar a rede de transmissão oral e seus saberes, aprendendo e ensinando o canto, a dança, o cordel, o "causo", a contação de histórias, os mitos, os repentes, as quadras e outras linguagens de tradição oral com o ensino formal. Para um Ponto de Cultura apresentar um projeto ele deve ter parceria com um educador de uma escola ou universidade; um griô aprendiz, no mínimo um griô de tradição oral e no mínimo um Mestre de tradição oral. A seguir uma breve descrição das características e obrigações da equipe necessária segundo o edital:

- Griô Aprendiz - pessoa com experiência e pesquisa em mobilização cultural, diálogo e mediação política; líder e/ou participante de grupos artístico-culturais e associações locais que trabalham com as tradições orais; pessoa com facilidade para transmitir a sabedoria da tradição oral por meio da palavra (oral e escrita) como uma arte ou ma- 
gia; pessoa com formação ou experiência em educação, letras, história, antropologia, artes cênicas, jornalismo e outras áreas afins; educador comunitário iniciado em facilitação de vivências em grupo; participante de rituais e/ou atividades de iniciação com um Mestre de tradição oral de sua escolha; escolaridade mínima de ensino médio.

Os Griôs Aprendizes são responsáveis por desenvolver e realizar o projeto pedagógico apresentado a Ação Griô e Ministério da Cultura, integrando o mesmo à escola e aos Griôs e Mestres, e se disponibilizando para as responsabilidades de aprender os saberes e linguagens dos Griôs e Mestres de tradição oral; promover o encontro de educadores, escolas e universidades com a cultura popular; e compartilhar as práticas pedagógicas e saberes de seu projeto que integrem a tradição oral aos currículos das escolas e universidades.

- Griôs de tradição oral - líder e/ou participante de grupos artístico-culturais e associações locais que atuam com as tradições orais e/ou animação popular de sua região; pessoa com facilidade para transmitir a sabedoria da tradição oral por meio da palavra como uma arte ou magia; músico instrumentista e animador de festas; pessoa com história de vida de tradição oral que se identifica com a figura do caminhante viajante e contador de histórias; idade mínima de 40 anos.

- Mestres de tradição oral - pessoas reconhecidas em sua comunidade como líderes espirituais com a sabedoria da cura ou da iniciação para a vida, buscados por pessoas de diversas regiões; conhecedores e fazedores de conhecimentos, iniciados ou iniciadores das artes e ofícios de tradição oral; pessoa com história de vida de tradição oral que se identifica com a figura do sábio e do mestre; idade mínima de 50 anos.

Os Griôs e Mestres Griôs devem realizar suas atividades de educação e cultura asseguradoras da transmissão oral de seus ofícios, saberes, linguagens e símbolos; participar ativamente das atividades articuladas pela rede Ação Griô Nacional bem como seus encontros de acompanhamento pedagógico.

Afinal, descrito todos os papéis e funções daqueles que atuam nos projetos apresentados pelos Pontos de Cultura para a Ação Griô Nacional, podemos adentrar aos relatos da história de vida dos Mestres Griôs com especial atenção para a sua inserção na rede, e sua caminhada à escola.

\section{Com a palavra, o Mestre Griô}

Na tentativa de analisar a participação dos Mestres Griôs na Ação Griô Nacional, procuramos observar as expectativas e experiências de quem são os protagonistas 
dessa história, por meio de suas narrativas de história de vida, registradas pelo Instituto Museu da Pessoa. As narrativas realizam um vínculo entre passado e presente problematizando a negociação de suas identidades tanto de forma individual como coletiva. Nela iremos ressaltar o papel desempenhado pelos Mestres Griôs na escola.

Acreditamos que as entrevistas constituem uma rica fonte de pesquisa. Nos depoimentos dos Mestres Griôs, buscou-se uma incursão em suas vivências, aprendizados e raízes históricas. Os relatos orais sobre o passado englobam fragmentos das histórias de vida e mostram como o modo de entender o passado é construído, processado e integrado à vida das pessoas (NOGUEIRA, 2000). Essa reconstrução do passado, seja em nível individual ou coletivo, está impregnada de identificação. Na seguinte pesquisa, procuramos demonstrar respeito a cada indivíduo não perdendo de vista a dimensão humana, principio fundamental da Historia Oral. Como mencionado na apresentação, foram analisados 5 depoimentos procurando selecionar relatos de mestres residentes em regiões distinta: Rio Grande do Norte, Pernambuco, Bahia, Rio Grande do Sul e Rio de Janeiro. Respeitando as diversas formas de narrativa, não realizamos alterações de ortografia ou sintaxe. Conservamos os relatos coletado com a preocupação de realizar o mínimo de intervenção possível.

\section{A experiência nas escolas}

Uma primeira constatação nos 5 depoimentos analisados foi que para todos os Mestres Griôs a experiência de entrada na escola é percebida de forma positiva. "A criança é muito receptiva. A criança, você sentou ali, começou a conversar com ela, eles estão abertos, escutando tudo.” (BAPTISTA, 2007: P.13. Entrevista concedida ao Museu da Pessoa em 16/09/2007). De acordo com o Mestre José Bernardo Pessoa, da cidade de Aliança, no estado de Pernambuco, é um prazer ensinar e aprender com os alunos:

"Eu gosto de conversar com os alunos mexendo com a cultura. (...) eu comecei nos colégios, dan-
do aula de maracatu para os meninos, Bil dava aula de coco, eu dava aula de cavalo-marinho tam-
bém. Os meninos gostam muito e a gente aprende com eles o que precisa pra ensina. Para mim
é bom porque chegar em um lugar com 40,50 pessoas querendo que você ensine a ele cantar
maracatu, ensine cantar ciranda, ensine cantar coco e dançar, é bonito. Aquilo dá um prazer para
quem está ensinando." (PESSOA, 2007: P.29). Entrevista concedida ao Museu da Pessoa em 2006

No relato do Mestre Aurino, da cidade de Lençóis no estado da Bahia, percebemos a alegria do Mestre em ensinar na escola a musicalidade da sanfona:

"a gente ia nas escolas fazendo visita, fazia alguma apresentação cantando, tocando alguma coisa que fosse possível. Canta junto as meninas, o pessoal, professor, todo mundo está junto. É muito alegre e a alegria faz parte da saúde da gente. Eu me interesso muito porque eu tenho o maior 
prazer, se por acaso eu morrer, de deixar quando nada uns dez ou vinte aprendizes, pra quando nada ficar a minha lembrança, que eu tenho lembrança com o povo." (SOUZA, 2007: P. 26. Entrevista concedida ao Museu da Pessoa em 08/07/2007)

Percebemos também, através das narrativas dos Mestres Griôs, a importância de se abordar histórias e conhecimentos que muitas vezes não encontram espaço no universo da escola.

Para o Mestre de capoeira Marcos Antonio, residente na cidade de Natal no estado do Rio Grande do Norte, incluir a capoeira como exercício da disciplina de educação física na escola pública onde leciona, foi uma tarefa difícil porém satisfatória. Para Marcos a disciplina de educação física poderia agregar elementos da cultura popular brasileira. Em suas palavras:

"É com o jogo da capoeira que eu atendo todas as necessidades na área de educação física. E acredito que podíamos incluir outros elementos brasileiros na educação física. Tem a peteca do Índio, coisa maravilhosa que é a cavalhada, a vaquejada, os jogos populares, as danças de roda, tanta coisa que, é uma riqueza enorme nesse país e nossa cultura pode se tornar recreação e educação física do povo brasileiro." (CARVALHO, 2007: 29) Entrevista concedida ao Museu da Pessoa em 07/10/2007)

Para Maria de Fátima da Silveira Santos, trabalhar na escola pode sanar o grande descaso brasileiro com o negro trazendo a luz heróis negros como Manuel Congo.

\footnotetext{
"A gente vai pra dentro das escola e trabalha com crianças, para elas pensarem e conhecerem o negro. Porque nada nesse país valoriza o negro, nada. E hoje os nossos heróis negros estão indo pra dentro das escolas, porque a gente está levando. Na minha época que eu estudei não se falava em Zumbi dos Palmares. A gente tem aqui a história de Manuel Congo que foi um negro enforcado porque fez uma rebelião com 400 negros reunidos das fazendas. Agora que a gente está dentro da escola, podemos trabalhar esses nomes,Manuel do Congo é um herói nacional!" (SANTOS, 2007: 03). Entrevista concedida ao Museu da Pessoa em 26/05/2007)
}

A fala desta depoente faz-nos lembrar que se trata não apenas de reconhecer a transmissão oral como uma forma válida para a reprodução cultural, mas também de reconhecer os conteúdos que as classes subalternas enunciam, e que a cultura hegemônica negligencia.

Mas a reflexão sobre oralidade como meio de transmissão e reprodução cultural, que não deixa de constar nos depoimentos dos mestres, também é bastante interessante. De acordo com Mestre Neives Baptista a criança

"não pode de maneira nenhuma deixar de aprender aquilo que é sua ancestralidade. O que inclusive é o nosso trabalho como Mestre Griô, é passar pra eles aquele nosso conhecimento. Nós queremos fazer com que ele perceba que aquilo ali é a sua raiz." (BAPTISTA, 2007: 13) 
Um conhecimento passado de geração em geração e que hoje reinventa o cotidiano da escola, relacionando-se com ela e criando uma nova história. Para Mestre Marcos, não é só nos livros e na nova tecnologia que podemos aprender. Mas também no conhecimento dos velhos, na experiência da vivência.

"É na oralidade, é na presença do mestre que realmente a gente vai sentir a essência do fazer daquela formula. É vendo e olhando, é nesse contato corpo a corpo com os mestres que a gente entende melhor, não vai ser apenas através do livro nem de uma tecnologia moderna também. Tem que haver um diálogo entre todas elas, o saber oral , a tecnologia e os livros." (CARVALHO, 2007: 22)

Mestre Aurino, em seu relato apresenta grande satisfação em participar dos Encontros Regionais realizados pela Ação Griô. Percebemos em sua fala o reconhecimento da integração entre o velho e o novo.

\footnotetext{
"Todo lugar que a gente anda tem união, mas aqui eu achei que foi mais um pouco do que os outros lugares. Uma coisa que eu achei ótimo foi isso, o rol de conhecimento e o rol de atenção à gente, muita atenção pra gente. Tanto faz novos como velhos, e ainda os mais velhos. Eu gostei muito, todo mundo fala com todo mundo, não tem diferenças de idade porque todo mundo aprende."(SOUZA, 2007: 27)
}

Após análise dos depoimentos, percebemos que a experiência do Mestre Griô na valorização da cultura local é percebida de forma satisfatória em todos os relatos.

\section{Considerações finais}

É de grande importância perceber que existem possibilidades de relacionamento entre a cultura hegemônica; no caso a escola; e a cultura popular subalterna dinamizando a cultura e dando voz a histórias e conhecimentos renegados pela história oficial. A entrada da tradição oral na escola pode ser alternativa para o enriquecimento do currículo escolar e para aproximação da escola com a realidade das diferentes comunidades brasileiras.

Assim é com iniciativas como a Ação Griô Nacional que visualizamos a possibilidade de projetos culturais que fomentam a valorização da identidade brasileira pautada também em seu povo e nas tradições que ele, apesar do despeito da hegemonia, carrega.

As narrativas dos Mestres Griôs se apresentaram como rica fonte de pesquisa para analisarmos os meandros que cercam o campo cultural brasileiro. Esperamos incitar novas pesquisas sobre o tema. 


\section{Referências bibliográficas}

CHAUÍ, Marilena. "Conformismo e Resistência: aspectos da cultura popular no Brasil”. São Paulo: Brasiliense, 1987.

FERREIRA, Maria Nazareth. "Os desafios da produção científica no neoliberalismo: as culturas e a comunicação subalterna". São Paulo: CELACC, 2002

HALL, Stuart. "Notas sobre a desconstrução do 'popular" in: "Da diáspora: Identidades e mediações culturais". Brasília: Editora UFMG, 2003.

MINISTÉRIO DA CULTURA. "Edital de Divulgação de Bolsas de Incentivo Griô número 02”. Brasília: Secretaria de Programas e Projetos, 2008.

NOGUEIRA, Ana Maria de Moura. "Como nossos país: Uma História da Memória da Imigração Portuguesa em Niterói, 1900-1950" in: "Revista Primeiros Escritos". Niterói: Laboratório de História Oral - UFF, 2000.

PACHECO, Líllian. "Pedagogia Griô: A reinvenção da Roda da Vida", 2a edição, Lençóis: Grãos de Luz e Griô, 2006.

RUBIM, Antonio Albino Canelas. "Políticas Culturais do Governo Lula/Gil: desafios e enfrentamentos". Trabalho apresentado no III Enecult, Salvador: UFBA, 2007.

SANDRONI, Carlos. "Culturas populares, circuitos de difusão e mercado. Seminário Nacional de Políticas Públicas para as Culturas Populares”. Brasília: Secretaria de Políticas Culturais do Ministério da Cultura, 2007.

SEMERARO, Giovanni. "Gramsci e os novos embates da filosofia da Práxis". Aparecida: Idéias e Letras, 2006.

\section{ANEXOS}

\section{Depoimentos}

1. BAPTISTA, Neives. Entrevista concedida ao Museu da Pessoa em 16 de setembro de 2007.

2. CARVALHO, Marcos Antonio Gomes. Entrevista concedida ao Museu da Pessoa em 07 de outubro de 2007.

3. PESSOA, José Bernardo. Entrevista concedida ao Museu da Pessoa em 06 de outubro de 2007.

4. SANTOS, Maria de Fátima da Silveira Santos. Entrevista concedia ao Museu da Pessoa em 26 de maio de 2007.

5. SOUZA, Aurino Pereira. Entrevista concedida ao Museu da Pessoa em 08 de julho de 2007. 


\section{Roteiro de perguntas}

1. Nome, local e data de nascimento.

2. Filiação e profissão dos pais

3. Infância (lugar onde morou, brincadeiras, comidas, amigos, histórias de assombração, músicas)

4. Juventude - primeiros trabalhos, paqueras, amizades, experiências no colégio, na faculdade, casamento.

5. Quando que o (a) senhor(a) começou a se envolver com a tradição oral? (adaptar para cada pessoa - se for música, o envolvimento com a música, etc.)

6. Com quem você aprendeu essa experiência/saber ?

7. Qual é a importância dos ensinamentos da tradição oral?

8. Qual a diferença desta tradição para a formal/escrita?

9. Na tradição oral existem segredos que só são revelados para aqueles que se envolvem com esta prática. Gostaria de nos contar como foi seu processo de aprendizado?

10. Tem alguma música/história/verso/dança que o(a) senhor(a) poderia mostrar para gente?

11. Qual é o sentido/significado deste saber?

12. Qual é a importância no mundo atual destes conhecimentos continuarem a ser transmitidos?

13. Como você transmite os conhecimentos que possui para os mais jovens?

14. Como se deu o convite para ser um mestre griô?

15. Como se sente sendo um mestre griô?

16. Qual a importância de deter este tipo de conhecimento e ser considerado (a) mestre griô?

17. O que significa para você a Ação Griô? (qual a importância, etc.)

18. Qual é a sensação de estar fazendo parte deste encontro?

\section{Entrevistas}

Seguem os depoimentos transcritos na íntegra. Eles estão disponíveis também no site do Museu da Pessoa: www.museudapessoa.net . 


\section{Depoimento de Neives Baptista \\ Entrevistado por Antonia Domingues e Thiago Majolo \\ Presidente Getúlio - RS \\ 16 de setembro de 2007 \\ Realização Museu da Pessoa}

P/1: Então, eu vou pedir pro senhor repetir o nome e o local de nascimento.

R: Meu nome é Neives Baptista, eu sou natural da cidade de Pelotas do Rio Grande do Sul, $250 \mathrm{~km}$ adiante de Porto de Alegre. E eu nasci em Pelotas em 1936. Portanto, eu tô com 71 anos.

$\mathrm{P} / 1$ : Qual que era o nome da mãe do senhor?

R: Bernardina Meirelles Baptista.

$\mathrm{P} / 1$ : E o teu pai?

R: Ramón Baptista.

$\mathrm{P} / 1$ : Qual que era a atividade deles?

R: Meu pai era oleiro. Trabalhava em olaria. E a minha mãe era doméstica.

$\mathrm{P} / 1$ : E o senhor "se recorda" do trabalho deles?

R: O meu pai era encarregado de uma seção de manilhas. Manilhas, naquela época, se usava muito em esgoto. Ainda não existia esses canos práticos, né, de brasilite, e se usa manilha de barro vidrada. E ele trabalhava na Cerâmica Pelotense. E a Cerâmica Pelotense eu acho assim, no meu ver, que ela tava muito adiantada pra época, por que ela quebrou em 1959... Em 59 ela quebrou, desistiu. Na Cerâmica Pelotense eles tinham máquina, na época, máquina da Alemanha, máquina da França... Então, tinha máquina pra fazer telhas francesa, tinha máquina pra fazer telha nacional, tinha máquina pra telha paulista e tinha máquinas pra fazer tijolo refratário. Então, se fazia de tudo na Cerâmica Pelotense. Pra época era muito adiantada, tinha tudo que era negócio pra construção, existia tudo, desde a área, do cal até o cimento. Inclusive tinha uma fábrica de ladrilhos. Por exemplo, hoje em Pelotas, se procurar com calma, ainda vai ver muito material da época da Cerâmica Pelotense. Eu digo isso, até com um pouco de emoção, por que quando eu entrei pra Cerâmica Pelotense eu tinha 16 anos, eu era muito jovem. E ninguém esperava, por exemplo, que a Cerâmica Pelotense fosse quebrar! Por que ela tinha um movimento muito grande de venda de material. Ela vendia material pra todo o estado do Rio Grande do Sul. E pra surpresa 
nossa foi anunciada a quebra da Cerâmica Pelotense. Então, eu digo isso hoje, com muita tristeza... E inclusive fez parte do meu inicio de venda, nesta vida. E lá trabalhava eu, trabalhava o meu irmão, trabalhava o meu pai, trabalhava um tio meu, por parte... um irmão da minha mãe. Então, quando faliu a Cerâmica Pelotense... Eu tô falando, praticamente, da minha mocidade e é por isso que eu me emociono.

\section{$\mathrm{P} / 1$ : O senhor se lembra como era a cidade, quando o senhor era criança?}

R: Eu tenho até impressão que eu fiz parte... Eu faço parte da história da cidade de Pelotas. Eu posso contar muita coisa. Mas, Pelotas não era uma cidade grande não, é uma grande cidade. Inclusive pra quem não sabe, Pelotas é a cidade aqui no Sul do país, que tem o maior numero de negros, só perdendo para salvador e para o Rio de janeiro. Em Pelotas teve uma atividade muito grande dos escravos, devido as charqueadas. Pelotas mandava na época, charque pra Europa. Era usado trabalho escravo. Então, tinha muito negro. Depois terminou a escravidão e os negros ficaram lá em Pelotas. Hoje é uma cidade, segundo o censo do IBGE, parece que tá com 300.000 habitantes ou 320 alguma coisa assim. Mas, como se trata de uma cidade, basicamente, central, que envolta da cidade de Pelotas existe muitos municípios. Eu creio hoje que Pelotas deve tá em torno de 400.000 habitantes ou mais. Então, as vezes eu fico me lembrando... Eu não nasci em Pelotas por castigo. Pra mim Pelotas foi um presente de Deus. Eu me sinto muito bem em Pelotas. Eu nasci lá, me criei lá, me casei lá! Criei meus filhos em Pelotas. Era uma cidade muito civilizada. E veja, por exemplo, Pelotas tem "duas universidade" $\mathrm{e}$ "duas faculdade". E existe uma escola técnica lá também, federal que era Escola Técnica Federal, aonde abriga um número grande alunos, não sei o número exato, mas tem muitos alunos. Eu me orgulho muito da cidade de Pelotas e eu gostaria até, pra aproveitar esse ensejo, para as pessoas vir conhecer Pelotas, é uma cidade turística, tem muita coisa pra se ver lá. E eu tô aproveitando por que a mídia hoje, nacional, ela ta centrada muito para outros estados, mais central, do Nordeste, então a mídia se voltar para o interior do Rio Grande do Sul, principalmente. Então, eu convido quem estiver assistindo a essa entrevista, esse vídeo, que venha visitar Pelotas.

P/1: E o senhor conhece as histórias do seus avós, bisavós?

R: Não. Não conheço. Não foi passado pra mim essa história. Eu conheci meus avós maternos que foram o vovô Damacedo e a vovó Manuela já falecida, já foram embora a muitos anos, "tão" quase reencarnando já. Então, eu tenho essa lembrança deles, até com muita saudade. Mas, assim, história mesmo deles, eu não... Não passaram isso, eu não sei.

$\mathrm{P} / 1$ : O que eles faziam? 
R: Olha a lembrança que eu tenho dos meus avôs, eram como aposentados. Era caseiro, estavam separados, já a muitos anos. Ele mesmo fazia a comida dele, vivia sozinho. E a minha avó, a falecida Manuela, ficou cuidando dos filhos. Eles tinha uma distancia de moradia de mais ou menos uns 5 quilômetros, a distância entre a vovó e o vovô. Mas, eles praticamente, não... Eles cortaram a ligação, não se davam mais. Porque também, eu não sei qual é o motivo. É só o que eu me lembro deles. Mas, era pessoas muito honestas, muito sérias. Uma época em que se cobravam muito das pessoas, probidade que tivesse vergonha. Eram pessoas com muita vergonha, muita probidade. Agora, o porquê eles se separaram eu até hoje não sei, não procurei saber também. E aonde estiver, a minha saudade e o meu respeito.

$\mathrm{P} / 1$ : $\mathrm{E}$ o senhor mencionou que o pai do senhor era Uruguaio, como que ele veio para o Brasil?

R: O meu pai nasceu no Uruguai, na província de Melo. Numa fazenda chamada Cinturion. E o meu avô, pai do meu pai, ele era do exercito lá no Uruguai, deu uma revolução lá e o pai do meu pai teve que fugir para o Brasil e trouxe as crianças junto. E o meu pai entrou aqui por Jaguarão, e veio se instalar em Pelotas. Não voltou mais, até a época que eu me lembro ele tinha a língua meio enrolada, ele não conseguiu assumir o idioma, o português na sua totalidade. A ele também tenho os meus respeitos, a minha saudade, foi ele que meu a educação, esteja aonde ele esteja, muita luz pra ele.

$\mathrm{P} / 1$ : E como era a cidade quando o senhor era criança, as brincadeiras, como que era o dia-a-dia?

R: Olha, eu pude até dizer que eu tive uma infância. Hoje a gente vê essas crianças cheirando cola, viciado em cocaína, usando craque, tudo essas porcarias que tão aí. E na minha época não existia isso, por que nós tínhamos uma infantilidade, muito assim, como é que eu vou explicar... Muito saudável. Então, nos brincávamos. Era uma época inclusive... Por que em Pelotas teve bonde, né? Existia bonde em Pelotas e até agora não tinha nada o que fazer, então a gente se dependurava nos bondes pra, na época nós dizíamos, pra gozar... Nós diziamos: "Vamos gozar." Quando chegava perto do fim da linha nós puxávamos a corda, que era a ligação do bonde, que o bonde era elétrico, tinha um fio em cima que ocorria a alavanca que passava a corrente pro bonde elétrico. E nós puxávamos. No momento que nós cortava aquilo ali o bonde parava e nós saiamos disparando. Era uma infância muito saudável. Tinha diversos tipos de brincadeira, na época, a gente jogava bolinha de unha que chama hoje, bolinha de gude, a gente jogava buraco, fazia o triangula e pulava ali em cima... Teve diversos tipos de brincadeira que a gente fazia quando era mais jovem. Eu me lembro com muitas saudades, apesar que a partir daí, de uma certa época, eu passei a me comprometer mais com o social. Meus pais tinham vaca de leite e eu 
tinha que levar de manhã as vacas pros campo e depois de noite teria que buscar. $\mathrm{E}$ eu ia ajudar o parceiro do meu pai, também a ordenhar as vacas. Aprendi, inclusive, a tirar leite. Entregava leite. E a partir daí o meu tempo de criança foi se eximindo. Então, as brincadeiras, praticamente, foram parando. Eu muito jovem eu já comecei a assumir a casa, que nós éramos cinco irmãos. Eu digo éramos por que uma irmã já foi embora, já partiu pro mundo espiritual. E o meu pai era analfabeto, a minha mãe semi-analfabeta. Então, a gente tinha inúmeras dificuldades pra se sustentar, pra sobreviver na época. E, então, meu pai disse que eu ia parar de estudar, é por isso que eu deixe o primário. Eu não consegui ir além do primário, por que meu pai disse pra mim que "eu fosse parar de estudar" e fosse trabalhar. Na época eu me lembro que a minha mãe: “Mas, o nego tá tão adiantado! Já ta no quinto ano aí." E ele disse: "Mas, já ta bom de estudar. Já aprendeu a ler e a escrever. E mesmo que nego nunca vai ser doutor. Então, ele vai trabalhar pra ajudar a criar os irmãos dele”. Foi quando eu trabalhar na Cerâmica Pelotense. É mais ou menos o que eu me lembro, por que já faz muitos anos, já. Eu to com 71 anos, né? Eu to falando de praticamente, 65 anos atrás é muita coisa. É isso aí.

\section{$\mathrm{P} / 1$ : E essa brincadeira do buraco como é que era que o senhor mencionou?}

R: O buraco é... Eles faziam uns triangulos e uns retângulos e a gente pulava ali. Só que era de um pé, não podia errar, tinha que pular com um pé só dentro do buraco e as vezes, tinha uma distancia de um metro e as vezes, você desequilibrava, caia e estava ferrado, perdia a aposta. E se jogava também a bolinha de gude, que naquela época a gente fazia com os dedos assim, e tinha que botar a bolinha aqui dentro aqui, desse arco aqui e se fazia a bolinha de unha que se fazia um triangulo e atirava a bolinha, pra tirar a bolinha de dentro, e pegava se acertasse a dali, pegava e botava no bolso. Era coisa de guri mesmo. Então, a minha infância, praticamente, foi saudável. Mas, não foi muito tempo não, como eu tô dizendo, eu tive que imediatamente assumir os meus irmãos também e eu tenho outro irmão mais velho que eu começamos a trabalhar pra ajudar a sustentar a família, tinha mais três irmãs também, que eram menores que nós. Nós morávamos numa casa alugada, na época, e o aluguel tava nos comendo por uma perna. Aí foi quando o pai resolveu comprar um terreno, e partimos para fazer a residência nesse terreno. Começamos a trabalhar para pagar o terreno, depois compramos na própria Cerâmica Pelotense o material a prestação, pagávamos por mês e conseguimos fazer nossa residência. Então, a gente tava ocupado, a gente não tinha tempo pra droga, certo? A gente trabalhava, a gente assumia a família então, a minha infância não foi assim, muito longa. Eu tive uma infância, mas não foi muito longa não, com treze, quatorze anos eu comecei a pegar compromissos sociais. Ajudar a criar a família. E ali já comecei a trabalhar, já fui pra dentro da fabrica e eu sou feliz por causa disso aí. Eu não parti para delinqüência. Eu me considero hoje, uma pessoa de bem. Eu gosto de gente, eu me sinto muito bem quando eu tô no meio das pessoas. E é isso aí. Mais alguma pergunta? 


\section{$\mathrm{P} / 1$ : A gente vai continuar fazendo. $\mathrm{E}$ quantos irmãos eram?}

R: Cinco. Dois homens e três mulheres. Hoje uma irmã já foi embora, a mais velha já nos deixou. Então, restam quatro irmãos só. Eu tenho outro irmão com 73 anos.

\section{$\mathrm{P} / 1$ : E como é o relacionamento com os homens, as mulheres, irmãos, irmãs?}

R: Era muito bom, por que a gente não tinha motivo pra brigar, todo mundo trabalhava. Tudo mundo trabalhava e não existia tempo para briga. Então, nós nos amávamos e dentro daquele sacrifício que nos foi imposto. A gente começou a trabalhar. Então, enquanto um trabalhava, a outra fazia comida, certo? Quando o outro trabalhava, o outro lavava roupa. Todo mundo tinha responsabilidade dentro de casa. E a minha cobrava muito dos filhos, dava muito duro nos filhos. Graças a Deus hoje tá todo mundo casado, todo mundo casou e todo mundo tem filhos, eu tenho filhos, o meu irmão tem filhos, as minhas irmãs tem filhos também, tão casada. Então, a gente não partiu pra delinqüência, a gente tinha compromisso na época, os pais nos cobravam, nós tínhamos um compromisso social. Social e espiritual, que inclusive, que essa entrevista que eu tô dando aqui pra vocês faz parte já desse privilegio espiritual, por isso que eu falo eu nasci na cidade de Pelotas e não foi uma oposição do sistema, foi um presente, eu nasci em Pelotas por merecimento. Eu espero continuar sempre merecendo essa atenção dos Orixás, dos donos da vida sempre me cuidando. Então, hoje pro exemplo eu tô aqui numa situação de Griô, Mestre Griô. Então, tudo isso aí é um presente divino, a mim só cabe agradecer, essas coisas bonitas que eles botam nas minhas mãos, eu sou um privilegiado.

\section{$\mathrm{P} / 1$ : Tinham festas religiosas na casa, quando o senhor era criança?}

R: Tínhamos. As festas religiosas naquela época eram católicas. Eu fui batizado, fui crismado, numa igreja católica. Eu tive uma doutrina católica. Só que na época eu tava ali, mas já tava meio desconfiado. O meu bojo espiritual queria outra coisa. Com o decorrer dos anos eu fui me espiritualizando, e passei a praticar a Umbanda. Hoje eu tô um pouco afastado, que eu tive muitos anos dentro da religião da Umbanda e hoje eu tô agora... Eu fui espiritualizado, eu mediunizado dentro da Umbanda, mas eu tenho um grande respeito na Igreja Católica. Eu acho que inclusive a humanidade, eu acho não, eu tenho certeza, que a humanidade deve muito ao catolicismo, pelo o que eles fizeram pela humanidade e continuam fazendo. Mas, eu já era meio espiritual na época, eu desde de guri eu enxergava, eu nunca acreditei em morte. Eu me lembro uma vez, que o meu tio faleceu e na época em Pelotas se costumava a velar o corpo das pessoas na casa, na sala da casa. Inclusive, na época se botava uns fumo, que era uns pano pretos, botavam na porta pra anunciar que ali estava sendo velado um corpo. E o meu tio tava se velando na sala lá de casa, e eu tava umas três ou qua- 
dro peças da onde ele tava, eu tava lá na cozinha... Daqui a pouco eu chamei a mãe e disse: "Mãe, vem cá!”. E ela: “O que é que foi?”. Eu disse: “O tio não tá morto.” E ela: "Como não tá morto?" Eu: "Ele passou aqui agora, tava brincando. Inclusive, olha lá onde ele tá, ele tá na volta do caixão, olha ele lá”. Ela: “Tu ta enxergando?!” E eu: “Tô enxergando!". Então, eu já tava me espiritualizando, eu passei a partir dali a estudar o que é a morte. Eu resolvi até tirar umas conclusões, que a morte não existe. A morte é meio e não é o fim. A partir dali eu passei a me interessar mais pelo espiritismo. Eu queria saber aqueles fenômenos que aconteciam comigo. Até hoje eu ouço vozes, eles falam comigo. Eu me lembro que esses tempos eu tava em Porto Alegre dormindo e eu fui atacado por umas entidades da pesada. E veio uma voz, que eu botava minhas guias na beira da cama, por que as guias falam que não dormisse com as guias, e eu tirei e fui atacado. Quem mandou... O que eles queriam também, eu não sei. Veio uma voz e me acordou: bota tuas guias. E eu disse: “quem que é?" E disse: "Bota tuas guias!". Aí, é claro, eu peguei as minhas guias e botei e aí saíram arrastando corrente. Eu tenho um contato com o mundo espiritual muito grande. Resumo: eu tô mediunizado, eu sou um médium. Eu não acredito na morte, a morte é um meio, não é o principio e nem o fim.

$\mathrm{P} / 1$ : o senhor se lembra mais ou menos, quantos anos o senhor se deu conta disso?

R: Ah! Eu era criança. Eu me lembro uma vez que me bateu, eu não me lembro que doença que era, se foi varicela ou varíola, tinha uma epidemia que tava dando lá em Pelotas que tava até matando criança e me deu essa doença. E meu pai mandou chamar um cidadão que receitava homeopatia que eu já tava desenganado pelo médico. Tanto é que eu já tava abandonando o corpo. E aí chamaram o falecido, seu Sossó e ele começou a me dar homeopatia de cinco em cinco minutos. E eu me lembro de quando ele chegou, eu tava em cima, eu tava no alto e tinha umas entidades junto comigo ali também. Eu já queria partir e disseram: "Não, não, não... Não, parte, não! Isso aí agora vai dar certo!" Disseram pra mim: "Isso vai dar certo! Volta pro teu corpo!” E realmente começaram a me dar aquele negocio de cinco em cinco minutos, mas eu lá de cima tava enxergando tudo aqui em baixo, inclusive o meu corpo. Aí foi quando eu retornei e hoje eu tô aqui. Então, eu sempre enxerguei essas coisas espiritual, eu sempre tive em contato com o mundo espiritual. E aí passei a estudar o espiritismo, praticar o espiritismo por que eu posso dizer hoje que eu não sou, eu estou no espiritismo há cinqüenta anos ou mais. Por que ser espírita ou ser umbandista requer uma serie de virtudes angelicais que eu ainda não possuo, certo? Agora, a minha prática é o espiritismo. Acredito, tenho convicção e hoje eu me encontro com vocês dando essa entrevista por que vocês, também estão fazendo parte desse contexto. Não existe casualidade, existe propósito. Vocês tem um propósito, eu tenho um propósito e os donos da vida também tem um propósito, e é esse que eu "tô" fazendo aqui. 
$\mathrm{P} / 2$ : Só uma pergunta sobre o espiritismo: Nunca o senhor teve medo de nada do que viu?

R: Não, por que eles nunca me fizeram mal. A primeira vez eu tive medo! A primeira vez, quando apareceu a entidade pra mim no pé da minha cama, eu era muito jovem, eu tava dormindo no meio, por que o quarto tinha o meu irmão mais velho dormindo a minha esquerda e o meu tio já falecido na minha direita, eu tava no meio. Aí tocou a campainha e eu acordei e vi aquela entidade nos pés da minha cama: branco, chapéu panamá, roupa branca, sapato preto, gravata vermelha, ele não me agrediu, não me violentou em nada e fez um contato comigo espiritual. $\mathrm{O}$ espírito não fala. Ele fez um contato comigo espiritual, eu me lembro como se fosse hoje, ele disse: "Não te assusta que eu sou teu amigo e protetor, eu tive contigo até agora." Eu já tava com sete, oito anos mais ou menos. E ele: "Eu tive contigo até agora. A partir de agora, eu vou subir, eu vou te abandonar que é pra tu desenvolver o teu livre arbítrio e toma conta da tua vida." Aí, mas, eu tava apavorado! Eu tava simplesmente apavorado, eu queria gritar e não podia. Aí, ele saiu em direção a cozinha aquela entidade, saiu pela parede e desapareceu. Quando ele desapareceu tocou a campainha, aí foi como eu consegui abrir a voz. Aí, sim eu botei a boca no trombone de vez: "Mãe! Pai!Tem uma assombração aqui dentro de casa!" Aí, vieram lá, me acordaram. E eu disse: "Não, aqui eu não durmo mais!” Fui embora lá pro meio das camas, com eles, que eu era muito criança e foi a primeira vez que eu me assustei. Então, como eu tava dizendo pra vocês, eu sempre tive em contato com o meio exterior. Hoje em dia eu não assusto mais. Mas, alguma pergunta?

$\mathrm{P} / 1$ : Como é que a família lidava com isso, com a mediunidade do senhor?

$\mathrm{R}$ : Ah! Eles estavam, simplesmente, preocupados! Por que teve uma época que o espiritismo era visto como coisa do demônio, coisa do diabo ou loucura, inclusive, na época muita gente foi levada aos psiquiatras por que eles achavam que aquilo era uma manifestação de loucura, de demência. Então, eles estavam simplesmente, assustados. Eu me lembro uma vez, também, que eu enxerguei uma entidade e a minha mãe me pegou e me levou lá na igreja, aí, pediu uma audiência com o padre lá e disse: “É, esse negrinho tá enxergando entidades, pessoas mortas e a gente veio aqui pra ver o que dá pra fazer". O padre: "O que é que tu enxergava?". E eu: "Enxerguei isso, isso e isso...". E ele falou assim: "Isso aí é obra do satanás, isso aí é coisa do demônio". E eu disse: "Não é padre, eles não me fizeram mal, eles até conversam comigo." E ele: "Mas, é... Isso é obra do satanás!” Aí, eu ia fazer o que? Então, a partir dali quando eu tinha essas visões, eu não falava mais para os meus pais, por que senão eu ia terminar no hospício. Eu ia terminar num hospital psiquiátrico. Então, a maneira deles lidarem com aquilo era que eu não falasse mais que eu tava vendo essas coisas. Era a maneira que eles lidavam com isso aí. E depois de grande, eu passei a mediunizar, a participar dessas peregrinações espíritas, foi aí, que eles se convenceram que eu tinha um dom 
espiritual. Aí, passaram a me respeitar mais, inclusive, passaram até a socorrer das minhas entidades.

$\mathrm{P} / 2$ : Qual era a mensagem que ele te passou, aquele que falou que tava indo embora, que tava deixando o senhor por livre arbítrio? Qual era a mensagem que ele passava quando o senhor via ele?

R: Não, eu só ele uma vez, tanto é que ele se despediu: "Eu te acompanhei até agora. Desde o seu nascimento até agora. Era o seu protetor, meu guia, meu anjo da guarda, e agora estou me afastando que é para você desenvolver o seu livre arbítrio, pra tu cuidar da tua vida." E foi embora, foi o que ele me falou, mas ele não falou, ele usou a telepatia.

$\mathrm{P} / 2$ : Mas, o senhor viu outras pessoas?

R: Vi! Até hoje eu enxergo!

$\mathrm{P} / 2$ : Mas, eles passam alguma mensagem? Eles ficam quietos?

R: Não, se eles tiverem que passar alguma mensagem eles passam. Inclusive, eu sou médium, eu incorporo, sou um médium falante, certo? Eu recebo entidade mensalmente, semanalmente. E graças a Deus que essas coisas aconteceram comigo, é por isso que eu falo, eu sou um privilegiado. Então, é por isso que eu digo que a morte ela é um meio, não é um fim. E nós que estamos conversando aqui, somos irmãos, somos espíritos que estamos na matéria aqui. É nos temos uma missão, uma função pra cumprir aqui na Terra, e pra evoluir. È isso que os senhores estão fazendo aqui nessa matéria. E eu praticamente, to no fim, por que eu tô com 71 anos. Mas, eu continuo obrando e vocês estão iniciando, vocês tem muita coisa na frente, na vida de vocês. Mas, vocês já estão tendo sucesso, estudaram pra isso e vão ter mais sucesso ainda, tenho certeza disso aí.

$\mathrm{P} / 1$ : $\mathrm{E}$ aí, o senhor falou que a partir de um momento o senhor não podia falar pra família, e como é que o senhor lidou com isso?

R: Não, aquilo ali passou a ser pra mim, normal. Inclusive agora se tiver... Eu não tô sozinho aqui, eu tava numa conversa, como eu tô conversando com vocês aqui. Aquilo passou a ser, passou a tá dentro da normalidade pra mim. Eu fui mediunizado, me explicaram como é que era, por que era, quem era eu, da onde eu vim, por que eu vim, pra onde eu vou, por que eu vou. Então, hoje, mais ou menos, eu tenho uma convicção de quem eu sou e por que eu tô aqui. Inclusive, disseram pra mim, você não tenha medo da morte, por que cada vez que tu tá dormindo, tu tá em ensaio com ela, tu ta fazendo contato com a morte, a morte é um sono. 
$\mathrm{P} / 1$ : E esse momento de livre arbítrio como é que foi? Depois que esse espírito saiu da vida do senhor, como é que foi depois?

R: Ah, isso aqui é uma delas! Eu tô usando meu livre arbítrio. Vocês também, têm o livre arbítrio de vocês. Por que se não fosse assim, Deus nos botava um cordãozinho, e nós seriamos marionetes, esses bonecos... Então, Deus nos deu o livre arbítrio. A gente faz o que quer fazer, só que tem que assumir as responsabilidades, tem que assumir as conseqüências dos nossos atos, certo? O nosso livre arbítrio nos leva, as vezes, a ascendência ou a descendência e pode nos fazer, as vezes, cometer desatinos. Por que como eu falei pra vocês, vocês são meus irmãos, eu sou irmão de vocês, não posso fazer mal pra vocês e vocês não podem fazer mal pra mim, por que nós somos dia e noturnamente observados. As coisas que acontecem com nós é pra "nós evoluir". E se botar uma pedra e a gente pular: "Puxa, essa pedra tava alta aí. Se eu conseguir mais vezes, ela vai ta mais alta". Tem que pular. Por que essa luzes que a gente enxerga no céu á noite, não é pra recriar as nossas vistas, isso são outros planetas, igual a Terra, e tem vida. Veja vocês, por exemplo, eu não sei qual é a religião de vocês, mas eu respeito todas, que na própria Bíblia, São João, o mestre Jesus fala: "Na casa do meu pai há muitas moradas, lá cada um receberá de acordo com suas obras." Qual é essas moradas? São as diversas camadas espirituais e os planetas. Tá certo? Tá na Bíblia! Alguma pergunta?

$\mathrm{P} / 1$ : Na história de vida do senhor, depois que esse espírito ele te deixou, esse anjo da guarda, assim, na sua vida o que começou a acontecer, na história de vida do senhor?

R: Depois que ele foi embora? Não. A tendência foi só a melhora! Então, hoje eu bendigo as coisas que se interpõe na minha vida eu fico até desconfiado quando as coisas facilitam pra mim, porque pra mim as coisas sempre foram difíceis. E essas coisas sempre houve dificuldade, que é pra mim exercitar o meu espírito, que é pra mim poder evoluir.... então não tem facilidade, no mundo espiritual as pessoas que são candidatos a evolução não tem facilidade quer aprender então vai pro sacrifício e é o que aconteceu comigo, mas em contrapartida também vem a compensação e essa entrevista que eu to dando aqui pra vocês é a recompensa ..entenderam? Isso aqui é a recompensa, esse trabalho que eu to fazendo aqui como Griô é a recompensa! Eu quero deixar bem claro pra vocês também que em 1969 eu ingressei na empresa Nossa Senhora da Penha e tive uma imensa dificuldade pra entrar nos quadros de motorista da empresa, mas eu venci, então eu quero deixar bem claro que eu fui o primeiro negro no Rio Grande do Sul que trabalhou na Nossa Senhora da Penha, quando eu falo Nossa Senhora da Penha eu digo com muitas saudades, uma empresa que me tratou como gente, eles foram cavalheiro comigo, depois de 20 anos que eu trabalhei lá, eu me aposentei lá, nunca me envolvi com acidente, eles fizeram uma festa pra 
mim, deram presente pra minha mulher, mandaram um carro leito em Pelotas me buscar, eu e meus convidados, eu podia trazer 17 pessoas nesse carro, e deram uma festa pra mim lá em Porto Alegre num restaurante italiano num rodízio de massas. E esse relógio inclusive aqui é um presente que eu ganhei deles, a minha mulher ganhou um faqueiro. Então quando eu cheguei na empresa Nossa Senhora da Penha eu pensei que eu era motorista, mas só aproveitaram a minha carteira e a minha boa vontade, houve uma reciclagem no profissional que eu pensei que eu era e me ensinaram tudo de novo, foi por isso que eu fiquei 20 anos na empresa Nossa Senhora da Penha e nunca me envolvi com acidente. Aconteceu coisas de ruim comigo?Aconteceu. Mas aconteceu muito mais coisa de boa, do que de ruim.Então é por isso que eu digo, esse livre arbítrio tem dois peso: se você usa o seu livre arbítrio pra ferir o seus irmão você pode se dar mal, se você usar o seu arbítrio pra dar carinho pro seu irmão, pra socorrer ele, pra dar caridade pra ele você vai se dar bem.

$\mathrm{P} / 1$ : Conta um pouquinho pra gente como o senhor entrou na olaria e começou a trabalhar fora de casa, como que foi?

R: Eu primeiro trabalhei numa fábrica de vidro, que lá em Pelotas existia duas fábricas de vidro,a Ideal e a Cruzeiro, então eu carregava vidro quente, saía da forma eu carregava num carrinho pra ir pro depósito, pro resfriamento ....e depois passei também a fechar forma, trabalhava sentado botava o vidro ali , a massa de vidro,e eu fechava a forma e ele assoprava, eu batia com o pé, eu abria a forma e ele tirava já o vidro pronto.Depois dali fumo embora pro curtume Carvalho Teixeras, tive num lembro quanto tempo, mas tive uma época boa no Carvalho Teixera, foi apartir dali que eu entrei na cerâmica Pelotense como oleiro, mas como oleiro eu entrei carregando tijolo, tijolo verde, nos carrinhos.... era um carrinho..como é que eu vou explicar? Ele tinha uma frente assim, que era pra escorar os tijolo e aqui do lado era aberto, com uma roda só. Então a gente carregava os tijolo, pegava o carrinho e levava pro gradeamento, e quando chegava lá tinha um funcionário que ficava esperando, ele mesmo tirava os tijolo do carrinho pra ir gradeando que é pra secar. Então na cerâmica pelotense, praticamente eu fiz carreira, depois eu passei pra ajudante de caminhão, depois de ajudante de caminhão eu aprendi a dirigir, eu tive lá uma alma boa, um espírito que me ensinou a dirigir, aí eu fui me embora, com 17 anos eu fui embora pra Bagé, fui servir em Bagé $220 \mathrm{Km}$ de Pelotas, servi no $3^{\circ}$ Regimento de reconhecimento mecanizado e motorizado, e lá então eu desenvolvi a minha profissão de motorista, quando eu voltei de Bagé eu já voltei então com uma carteira militar de motorista, eu só troquei ela por uma carteira de motorista civil quando eu voltei pra Pelotas, a partir dali começou a minha peregrinação como motorista e não demorei muito já peguei um caminhão na cerâmica pelotense,eu cheguei a motorista, foi justamente quando a empresa quebrou, eu era motorista da cerâmica pelotense. A partir dali eu trabalhei como táxi, foram 10 anos de vida noturna consecutivos, no tempo da vida noturna, que Pelotas tinha muita vida noturna, vida noturna romântica, hoje tá violenta, tão 
matando até motorista...então foram 10 anos, aí começou a terminar a vida noturna e já não tava dando mais lucro aquilo ali né, eu já tava no prejuízo, foi quando eu resolvi deixar os táxi. Aí eu fui pra um urbano em Pelotas, a empresa Turfe, trabalhei 2 anos, em seguida eu fui embora pro expresso embaixador, aquele que faz Pelotas - Porto Alegre, Pelotas - Chuí, Pelotas - Cambuçu, Pelotas - Rio Grande, então eu fazia essas linhas, aí tive 3 anos, aí foi em 66/67 entrou a Nossa Senhora da Penha em Pelotas, aí me apaixonei a primeira vista, amor a primeira vista, aí botei na cabeça que eu ia trabalhar ali, em 69 eu resolvi fazer teste na empresa Nossa Senhora da Penha. Então hoje eu vejo com muito orgulho, com muito prazer, com muita saudade, eu tenho saudade da empresa Nossa Senhora da Penha, eu fui tratado como gente como pessoa dentro da Nossa Senhora da Penha, eles nunca viram a minha cor nem meu tamanho tanto é que eu sai de lá condecorado pelo DNR e pela empresa Nossa Senhora da Penha Então foi uma passagem da empresa Nossa Senhora da Penha muito salutária muito benéfica na minha vida porque eu aprendi muita coisa, aprendi a ser gente, a ser homem e a ser motorista dentro da empresa Nossa Senhora Penha, então eu desejo pra essa empresa aí é toda felicidade, que eles tenha sucesso nesse comércio que é de carregar passageiros, que é carregar gente. E que Deus proteja eles.

\section{$\mathrm{P} / 1$ : O que primeiro chamou a atenção do senhor nessa empresa?}

R: A organização. É uma das empresas mais organizadas do mundo. Ela é tão organizada que ali as peças do ônibus é trocada por $\mathrm{Km}$, se você quer saber... Você embarcou num ônibus aqui em Pelotas, você quer saber o estado daquele ônibus, não precisa se preocupar, ele tem uma certidão, existe um livro neste ônibus, no porta-luvas dele, você pega aquele livro ta toda a história daquele ônibus ali que você vai dirigir. Então você vai ler ali, pneus dianteiros, foram trocados em Salvador na Bahia com tantos $\mathrm{Km}$ no dia tal/tal/tal aí se você olhar pelo velocímetro, o que marca a quilometragem, hoje em dia é tacógrafo, você vai ver quantos $\mathrm{Km}$ tem aquele pneu.Você quer olhar, por exemplo, caixa de câmbio: foi trocada em janeiro com tantos quilômetros, você olha no tacógrafo. Essa caixa tá boa foi trocada com tantos quilômetros, e ali no próprio certidão dele já tá com quantos quilômetros tem que ser trocado.Então ele tem um período de vida, e ali a Penha não deixa passar daquele período, e outra ela responsabiliza tanto o motorista quanto o mecânico, que se um ônibus pifar durante a viagem eles vão procurar saber quem é o culpado. Então não é fácil não, o motorista que ta viajando tem que cuidar de todos os pormenores daquela nave pra quando ele chegar na oficina, botar na ficha de oficina o que ele sentiu na viagem..se o carro tremeu, se oscilou, senão tá engrenando a marcha direito, se ta pegando, tem que botar tudo aquilo na ficha de oficina, que aí ele livra a cara dele, certo? Aí depois o mecânico que vai examinar. E se aquele carro quando voltar, pifar, eles vão procurar, por que essas fichas são tudo recolhidas para Curitiba. Eles vão procurar: "Mas, pifou e o mecânico não arrumou”. Aí, pobre do mecânico. Eles vêm em cima mesmo, não querem nem saber. Agora, também, eles não botam na rua assim, também, eles sim- 
plesmente recolhem e levam para escola lá em Curitiba. Então, você vai ser reciclado, por que isso aqui não pode acontecer mais. Por que, aliás, eles estão certo por que eles fazem uma prestação de serviço para o governo, que é o DNR. Então, aquilo ali é uma concessão e de repente eles podem perder até, a linha. Tem que andar direito. Eu vejo agora o que aconteceu com as linhas aéreas aí, que não podia ter acontecido aquilo. Morrer 199 pessoas! E olha aí, o que tá dando agora, o que tá acontecendo aí. Então, é o que tô dizendo, nós seres humanos estamos aqui para evoluir e não pode acontecer essas coisas. De jeito nenhum. E tudo isso eu aprendi na empresa Nossa Senhora da Penha, e eu aplico na minha vida, aplica no meu carro. Certo? Então, eu tive um exemplo de vida na empresa Nossa Senhora da Penha, eles me ensinaram a ser gente. É isso aí?

\section{$\mathrm{P} / 2$ : O senhor fez muitos amigos lá dentro?}

R: Não. Eu faço amigo aonde eu estiver! Vocês vão passar a ser meus amigos também, aonde eu estiver eu faço amigos. Eu fiz sim, eu fiz muitos amigos lá. Inclusive quando eu me aposentei, quando eu cheguei em Porto Alegre tinha um pano lá, dizendo "Meirelles, já estamos com saudades de ti. Não nos abandone!" Porque lá o meu nome de guerra na Nossa Senhora da Penha era Meirelles, que eu sou Neives Meirelles Batista, mas eu não uso o Meirelles, então a maioria me conhece como Mestre Baptista. Eu uso Neives Baptista, mas o meu nome lá era Meirelles, o nome de guerra na Penha. Foi uma passagem da minha vida e infelizmente, parei, deixei.

\section{$\mathrm{P} / 2$ : Depois dali o senhor foi pra onde?}

R: Eu me aposentei em 89. Em 1990 eu passei a freqüentar o carnaval, o mundo da percussão, que é o que tava no meu bojo espiritual. Certo? Então, a primeira bateria show de Pelotas fui eu que tive o privilegio de montar. Eles nem sabiam o que era a bateria show. E olhe que o carnaval de Pelotas já foi o segundo e o terceiro do Brasil. Por que pra quem interessar possa em Pelotas tem muito negro, é uma das cidades mais negras do Brasil, só perde pra Salvador e pro Rio de Janeiro,. E do Sul do país, é uma das cidades mais negras. Eu creio eu que é por causa das charqueadas, teve muito negro lá em Pelotas e tem. Então, o carnaval de Pelotas. Inclusive eram 7 dias da semana de carnaval e eu me lembro quando eu tava na empresa Nossa Senhora da Penha, que eu tava em atividade, nós ficávamos com alguns ônibus lá, quatro, cinco, seis ônibus lá no Rio de Janeiro na quarta feira de cinzas pra quando terminasse o carnaval trazer as pessoas do Rio pra assistir o carnaval de Pelotas. Depois eu passei a ser ensaiador, eu ensaiei todas as escolas de samba de Pelotas. Idealizei uma escola de samba em Pelotas. Se vocês ouvirem falar da Imperatriz de Pelotas, foi eu quem idealizei, e junto com um presidente de uma associação o sr. Benedito, nós montamos a escola, e hoje essa escola existe lá. E partir daí eu passei a confeccionar instrumento de percussão. Aí foi me lançado um desafio pelo artista, compositor e cantor de Porto 
Alegre. Um Pelotense ilustre que nunca esqueceu das origens, nunca esqueceu da cidade dele. Ele veio guri para Porto Alegre e ele tinha um projeto em mente e quando ele foi captado pelo governo do Estado, senhor Olívio Dutra... O Olívio Dutra abraçou esse projeto com ele. Então, ele montou um projeto que era uma homenagem aos contemporâneos da época do sopapo, o instrumento sopapo. Aí, ele me procurou pra ver se eu confeccionava os quarenta instrumentos. Como não existia mais, por que até 1970 as baterias de Pelotas usavam esse instrumento, mas depois foram se acomodando, e veio esses instrumentos sintéticos de náilon, essas coisas todas, mas levianos por que o sopapo tem um metro de altura, ele é pesado. E então, deixaram os sopapos de lado. E deixar bem claro que o sopapo inclusive, bate com as mãos... É mais ou menos o que eu sei, bate com as mão, tem que ter habilidade. E me pediram para fazer os instrumentos e eu disse: "Faço." Queriam saber como é que eu ia fazer. Mas, eu daí: "Como é que eu vou fazer não interessa. Tu quer que eu faça o instrumentos.” E eles: "Então, ta... Eu aguardo.” Aí, eu fiz contato com o exterior, com os espíritos e aí eles me ensinaram como é que eu tinha que fazer. Então, o sopapo é um vaso, como isso aqui... Ele tem uma base 52, 55, de boca e 1 metro de altura. Ele é feito com compensado 4 milímetro, por que em Pelotas não vai mais 3 milímetros pra lá, inclusive isso torna o sopapo um pouco pesado. E leva ferros, leva 4 aras de ferro, leva um embaixo pra manter o instrumento redondo, leva outro por dentro que é pra manter o instrumento redondo, leva outro redondinho que é pra botar o couro, certo? E leva outro por fora que é pra puxar o couro por fora, que é pra afinar ele. Eu funciono, trabalho, com couro de cavalo por que em Pelotas é comercializado, tem até matadouros de cavalo lá e é comercializado a carne de cavalo só que é mandado pra França, lá pra Europa, por que lá em Pelotas não comemos carne de cavalo. E é comercializado o couro também, então eu pego o couro em natura lá do curtume e eu mesmo faço a constituição dele. O sopapo é instrumento de origem africana, um legado dos escravos, que deixaram em Pelotas, aquela área de Rio Grande, Pelotas, Guaíba, Barra do Ribeiro. É um instrumento muito gostoso de tocar nele, tem vários tons. Então, vamos supor que se você aprender a manusear ele, a tirar som dele, você não quer outra coisa. Foi feita até Orquestra de Sopapos de Pelotas. Coube a mim também, montar essa orquestra, então foram dois anos de plena felicidade. Mas, como se tratava de um projeto político, a gente sabia que ia terminar, e terminou! Por que o senhor Olívio Dutra não se reelegeu e o outro governo que assumiu, não quis assumir o projeto. O projeto, praticamente morreu. Aí, como tinha muita gente que tava envolvida, meninas, mulheres, tinha muita gente, a gente desfilava lá em Pelotas. Nós tínhamos uma orquestra de 40 sopapos, tudo trovoando lá... Por que o sopapo, pra quem não sabe, é um atabaque rei, só que algumas religiões usam ele, mas a maioria não usa.

$\mathrm{P} / 2$ : E sobre o instrumento, o senhor nunca vi nada quando era pequeno, nunca tocou nada? Isso surgiu já na fase adulta? 
R: Bom, em primeiro lugar, tu sabe que os descendentes de africanos já traz na alma, já traz no sangue essa musicalidade. Todo mundo sabe disso aí. Então, eu em menino já tocava quase todos os instrumentos de percussão. Inclusive, eu tocava violão. E depois que eu me aposentei um fiz um curso no Conservatório de Musica de Pelotas e passei a tirar o violão clássico. Eu tenho o violão lá em casa, eu toco o violão clássico. Então, desde menino que eu tenho essa tendência pra musicalidade, que isso tá no sangue da gente, certo? Não adianta a gente não querer, que tá, tá no sangue da gente. Eu inclusive da próxima vez que nós nos encontrar eu vou levar "três instrumento" meu, vou levar um sopapo, um exemplar pra "vocês conhecer", vou levar o bandolim, que eu toco o bandolim também e vou levar um instrumento que me celebrizou em Pelotas, a cuíca. De difícil manuseio a cuíca, e eu vou levar a cuíca também, então em novembro eu to levando esses instrumentos pra Belo Horizonte, se o pai permitir de eu ta lá e ver vocês novamente, vocês vão conhecer esse instrumento, eu desde guri que tive tendência pra isso aí, desde menino, inclusive no grupo escolar que escolar que eu estudava tinha uma banda lá de percussão, e eu sempre tive andamento, sempre tive ritmo e nunca atravessei o samba, certo?Então quando se oportunizou lá em Pelotas em 1990 , foi que eu comecei a mostrar aquilo mais ou menos que eu tinha em mente imediatamente me botaram um apelido: mestre Batista, esse é o mestre.Aí eu passei a ser mestre Batista, então vocês tão conversando com o mestre Batista, eu digo isso não com vaidade mas com bastante orgulho porque eu trabalhei muito pra chegar onde é que eu to, e trabalhei mesmo,pode ver que até couro eu curto, se vocês sentirem o cheiro desse couro de cavalo vocês cai duro, porque fede mesmo, eu tenho que chegar com eles em casa e meter diretamente no veneno, que é pra acabar com o cheiro, porque de repente até as moscas varejeiras,aquelas azul, vem atrás da carne, elas vem atrás da gente.Então me sacrifiquei muito pra chegar aonde eu cheguei , quando eu comecei com a bateria show lá em Pelotas sabe qual era o apelido da bateria show lá em Pelotas? Banda marcial, então tá cheio de banda marcial lá em passo, então hoje ninguém mais fala em mini-bateria, todo mundo é bateria show, então eu digo isso também com orgulho porque eu dei uma contribuição muito grande pro carnaval de Pelotas, então se você chegar em Pelotas, qualquer rua principal e você ver o movimento, onde é que falo com Mestre Batista? Já te diz, porque eu sou mais conhecido lá que erva ruim, pior que é , porque você quer aparecer em cidade do interior vai pro carnaval, porque as rádio falam, as televisão transmite então você se torna muito popular, muito conhecido, então eu sou muito conhecido lá em Pelotas lá, e é isso aí .

$\mathrm{P} / 2$ : E por falar em mestre, o que o senhor acha da Ação Griô qual a importância dela?

R: É uma boa pergunta. Olha, eu tô com 71 anos. Eu até pensei que eu tivesse terminado, acabado, tivesse chegando no fim. Eu já tinha até providenciado um túmulo lá em Pelotas. Comprar um ali mesmo, eu dizia: "É aqui mesmo que eu vou dormir...". 
Já comprava alguma coisa pra família. Eu achei que eu já tava no fim. Aí, de repente entra na minha vida esse tal de Griô. Eu me sinto assim, privilegiado em pertencer a um projeto a nível federal, a nível nacional, que é Ponto de Cultura Griô. E me procuraram, mandei meu currículo pra eles, pra Brasília e foi aprovado, eu passei a Mestre Griô. Pra mim o Griô faz parte daquilo que eu falei ainda agora pra vocês, da evolução dos espíritos. De repente o governo se volta pras minorias, que pra mim não é minoria, é maioria. Certo? Por que negros e pobres, e brancos pobres são maioria aqui nesse país. E aí, de repente o governo faz um projeto voltado pra essas minorias. Isso é divino. Eu tô muito contente, eu "to" muito feliz. Eu me acho assim, privilegiado. Eu tô tipo guri novo, quando ganha bala. Então, eu tô simplesmente assim, abismado, abobado, com o que eu vi nesse encontro aqui, que é o meu primeiro encontro, embora eu esteja cinco meses no projeto. Isso aqui faz eu me lembrar justamente, aquilo que eu falei pra vocês, a Nossa Senhora da Penha, a organização... Por que se vocês não sabem, eles estão nos preparando, por que a gente não sabe tudo. Eles tem uma proposta, eles fazem esses encontros que é pra justamente, nos orientar, para nos ensinar, o que nós temos que fazer. Eu tô simplesmente, apaixonado por esse Projeto Griô e eu espero eu que Deus ilumine essas cabeças aí, esses organizadores, esses coordenadores, esses projetistas que esse projeto não termine mais, por que o Brasil é um país de terceiro mundo, tem muita pobreza aqui, certo? Então, num momento, por exemplo, que acabar esse projeto, vai ser um desastre. $\mathrm{Ou}$ seja, esse projeto tá vendendo ilusões. Certo? São muita gente, aí. Eu sou um que tô ilusionado com esse projeto Esse projeto não pode terminar, tem muitas crianças que "tão" precisando desse Projeto. O que eu posso dizer pra sintetizar melhor ra vocês, eu tô tri apaixonado por esse projeto. Espero eu dar mais alguma coisa de minha vida, do que eu fiz pelo carnaval de Pelotas e aquilo que eu sei fazer, que eu aprendi até agora. Agora com as minhas limitações, que eu possa do Griô aproveitar essa oportunidade que eles estão me dando e levar isso que eu sei para essas crianças que estão precisando, essas crianças de periferia, que eu possa ajudar eles a tirar eles da rua, ou aqueles que não foram que também, não vá para rua. Arrumar uma ocupação pra eles, eles vão fazer instrumento, eles vão tocar instrumento, eles vão dançar. Eles vão ser tratados como gente. Esse é o trabalho do Griô, ele ta voltado para as minorias e a melhoria das pessoas, para a melhoria social das pessoas. É assim, que eu tô vendo o Griô. Alguma pergunta mais?

P/1: Como é que o senhor passa esse conhecimento para as crianças? Como é que é passar esse conhecimento que o senhor tem?

R: Não é muito difícil por que a criança é muito receptiva. A criança, você sentou ali, começa a conversar com ele, já tá aberto, já tá cuidando de tudo, já tá escutando tudo. Ele quer aprender, pra ele é muito bom por que ele sabe que não pode vacilar. Aqui ele vai ser profissionalizado, aquilo vai ser uma profissão pra ele. Ele não pode de maneira nenhuma deixar de aprender aquilo que tá ali. Aquilo, inclusive é o nosso 
trabalho como mestre Griô, é passar pra eles aquele nosso conhecimento. Nós temos que fazer com que ele entenda que aquilo ali é o futuro dele. As vezes a gente tem que passar, o que nem se deve dizer pra criança, que simplesmente um dia o pai deles vão embora. Certo? Que eles não vão sempre depender dos pais deles, que eles vão ter que aprender uma profissão. Eles têm que aprender fazer as coisas, que é pra poder sobreviver nesse planeta aqui. Então, não é muito difícil não ensinar a criança, que mesmo que nós trabalhamos com as escolas, com os grupos escolares, os ginásios, então, já são crianças que já tem uma certa disciplina. Quando essas crianças vêm até nós, que nós primeiro vamos eles, nós escolhemos a escola, qual tiver mais carente. Quando eles vêm pra nós, eles já tão preparados, as diretoras, as professoras já preparam eles. Então, eles praticamente, já sabem o que eles vão fazer "naquelas reunião" ali. Por exemplo, no meu caso, eu vou ensinar eles a fazerem o instrumento, não é só sopapo, surdo também, instrumento de percussão. Eu também vou ensinar eles a fazer isso aí. Então, simplesmente, eu vou pegar uma caneta, pegar o papel, aplicar a raiz quadrada pra eles. Eles tão na escola, eles sabem. Eu vou ensinar pra eles, tem que fazer assim, assim e assim: “O tio primeiro vai fazer agora, pra vocês aprenderem a fazer”. E aí, eu vou fazer. Necessita de uma serra, eu trabalho com uma serra tico-tico. Necessita de uma furadeira, que eu não trabalho com cola. É muito perigoso trabalhar com cola perto de criança. Eu trabalho com arrebite, aquele macho e fêmea e trabalho com "dois martelo", vou arrebitando o instrumento. Eu fecho esse instrumento pra eles, ensino eles, faço umas duas, três vezes. Aí, depois eu pego eles: "Agora, vocês é que vão fechar!" Eu tô ali ajudando, olhando: "Não, não é assim!” Até umas dez vezes vão continuar aprendendo. A gente quando vai numa escola, a gente faz um contato por um ano, num ano eles aprendem. Agora eu tenho em mente, nesse ginásio que a gente vai trabalhar com eles em Pelotas, inclusive até montar uma orquestra de sopapo. Eles vão fazer o sopapo, eu vou ensinar eles a tocar o instrumento. Desse ginásio vai sair a Orquestra de Sopapos de Pelotas. Então, eu já tenho mais ou menos uma prática disso aí. Tem a primeira bateria show, tem uma gurizada lá em Pelotas, isso foi, foi e foi até eu conseguir botar eles como eu queria, por que eu não abro mão da disciplina, sempre disse isso pra eles. E eu trabalho com três itens, quando eu tô trabalhando, ensinando, "muito importante" pra gente ter sucesso em qualquer coisa da vida que é a disciplina, a disciplina e a disciplina. Isso aí, eu não abro não. A não abro mão mesmo. Se quiser aprender tem que ter disciplina. Então, essa bateria que teve sucesso lá em Pelotas, a primeira bateria show lá em Pelotas ela hoje toca em santa Catarina, em Florianópolis, eu entreguei ela pro meu filho. Que filho de onça nasce pintado. E ele também é meio metido a ensaiador, então eu dei a bateria já contratada lá pra ele. Ele toca lá em Florianópolis, num dos maiores clubes de Santa Catarina que é o Lagoa Iate Clube. Todos os anos ele vem para Santa Catarina, Criciúma e em Florianópolis é essa bateria show que tá fazendo sucesso lá. Então, os meus meios para ensinar essa gurizada é isso aí: disciplina, disciplina e disciplina. Não brigo com eles, não xingo ninguém. Eu dou um trabalho, que praticamente, vai chamar a atenção deles, eu também, vou levar um exemplar e vou mostrar pra eles, o que eles 
devem fazer, vou tocar pra eles verem como é que é... Qual é a criança que não gosta de percussão, bem tocado, bem manuseado. É verdade, ou não é? Então, eles vão se interessar por aquilo ali, e quando vocês menos esperar eu tô com essa mini orquestra de sopapos pronta e nós vamos encantar o mundo, por que passa a ser tambores de Pelotas, que esse tambor, realmente, embora de origem africana são tambores fabricados em Pelotas. Eu vou fabricar eles, então são os tambores de Pelotas.

\section{$\mathrm{P} / 1$ : E era muito diferente essa forma de ensinar de quando o senhor era criança?}

R: Em primeiro lugar o seguinte, a mim ninguém ensinou. Já tá no meu bojo espiritual, como eu falei pra vocês é a descendência africana. Por que se vocês pegarem, por exemplo, uma criança branca e um neguinho e botar um instrumento de percussão ali; o nego vai se sobrepor. Isso já tá no espírito da gente. E não se esqueçam que a forma de comunicação que se iniciou no mundo foi através dos tambores. Até hoje, essa comunicação existe na África. Então, a gente tem que aprender a separar as batidas dos tambores que é pra ver o que é que aquela tribo tá mandando dizer. $\mathrm{Na}$ África usa os tambores, usa-se a fumaça também, fumaça branca, fumaça negra, fumaça azul. Então, os africanos, a madeira verde sabe como é que vai sair a fumaça, a madeira seca eles sabem como é que vai sair a fumaça. Se quiser, por exemplo, muito fogo, bota a água e já muda a cor da fumaça. É a maneira de comunicação deles. Então, os tambores faz parte, sim, da nossa vida. Os tambores é um legado dos Orixás. Eu, por exemplo, faço esses sopapos, pro carnaval eu faço de um jeito, pra religião eu faço de outro jeito, se trata de um atabaque rei, certo? E a nossa vida tá ligada a percussão. Se você parar e ouvir o seu coração, ele tá: tuco, tuco, tuco, tuco... Se parou, já era, morreu, mas é uma percussão. O negro, ele tá ligado por excelência, em principio, ele tá ligado a percussão. É claro que hoje, a gente tá um pouco longe de nossas origens. Faz muitos anos que nossos ancestrais foram libertados e de lá pra cá, ouve uma miscigenação na raça, e nos foi imposto uma série de costumes europeus que não tem nada a ver com o africano. Vocês vão ver hoje. Eu não tenho nada contra, mas vocês vão ver negros evangélicos, negros pastores, certo? Não é nada contra, mas não tem nada a ver com o africano, por que o africano, o que é, é percussão, dança, é sarava. O africano gosta de um sarava, que é essas religiões umbanda, candomblé, é tudo africano, os negros foram se distanciando, devido a essa miscigenação e dessas imposições, dessas coisas brancas que veio pro negro. Então, hoje é bem difícil você... Por que com o tempo esses mestres desapareceram. A tendência é desaparecer esses mestres, justamente, devido essas miscigenação e essas impostoras que a sociedade tá dando pra nós. O meu trabalho é ensinar, fomentar, preparar... Eu fico muito feliz quando vejo, por exemplo, essa gurizada que estão interessadas, principalmente "nego preto", esse nego bem retinto, me chama muita atenção. Se eu puder ensinar pra ele, orientar pra ele, trazer ele de volta para as origens dele, por que senão vai acabar os mestres. Então, eu vou ensinar ele, vou orientar ele. É por isso que eu dei a bateria pro meu filho, vocês vêem ele trabalhando na frente da bateria, parece que 
ele é um Deus incorporado, ele trabalha bonito, mas ele herdou de mim. Então, se vocês verem ele trabalhar na bateria vocês vão dizer: "Quem é esse negão aí?" Ele tá incorporado. É tipo uma orquestra sinfônica. Eu ensaio, eu preparo, eu crio os arranjos. Então, na hora eu sei o que é que tem que fazer. Eu não uso apito, eu só mando a senha, por que eles já estão disciplinados, estão orientados. Então, eles sabem que quando eu fizer isso aqui, eles sabem o que é. Eles já tão disciplinados, naquela maneira que eu quero trabalhar. É uma missão que eu tenho e eu quero cumprir ela. Griô me proporcionou e tá me proporcionando a fazer essas coisas espiritual, que eu quero fazer. O Griô pra mim representa muita coisa, pra mim ele é vida. Tô muito contente, tô muito feliz, tô muito privilegiado. Eu não to aqui por casualidade, eu tô sendo premiado em tá dentro do Griô e tô premiado e agraciado por essa entrevista que eu tô dando para vocês.

$\mathrm{P} / 2$ : A gente queria agradecer também a entrevista. Obrigado pelo tempo cedido.

R: Não, não tem nada que agradecer. Eu que agradeço, certo? Por que vocês pertencem ao quarto poder, certo? $\mathrm{E}$ o quarto poder decide. $\mathrm{O}$ quarto poder tem mais força do que os outros três poderes. Eu me sinto muito privilegiado por vocês me convidar a dar essa entrevista que a partir daí, eu to falando com o mundo. Tem muita gente que não me conhece e passa agora a me conhecer. Que essa mensagem que eu tô dando aqui, que vocês estão me proporcionando, é pro mundo. Eu agradeço essa oportunidade e assim que vocês precisarem de mais alguma coisa, alguma informação vocês tem meu telefone, tem o meu endereço, e pelo amor de Deus, não me abandone, eu preciso de vocês.

$\mathrm{P} / 1$ : Muito obrigada.

\section{Depoimento de Marcos Antonio Gomes de Carvalho Entrevistado por Winny Choe e Julia Basso Piaçabuçu Alagoas, 07 de outubro de 2007 Realização Museu da Pessoa Transcrito por Paula Leal}

$\mathrm{P} / 1$ : Marcos, pra começar, eu queria que você contasse seu nome, a data de nascimento e a cidade onde você nasceu, um pouquinho do começo.

R: Meu nome é Marcos Antonio Gomes de Carvalho, eu nasci em Canguaritamba, uma cidadezinha no estado do Rio Grande do Norte, aos 11 de novembro de 1954.

$\mathrm{P} / 1$ : E qual o nome de seus pais? 
R: Meu pai chamava-se José de Carvalho Silva, minha mãe Mariana Ivonete Gomes.

$\mathrm{P} / 1$ : E o que eles faziam?

R: Meu pai era herdeiro de um engenho e depois perdeu tudo por política, não é? E virou funcionário público na área da arrecadação fiscal, minha mãe era beata de igreja, e meu pai se engraçou da minha mãe, que já era casada e tinha uma outra família, e tirou por tirar minha mãe lá da igreja, e nós fomos ai sendo a segunda família do meu pai. Minha mãe depois fez um concurso pra funcionário público para ser tabeliã da cidadezinha.

\section{$\mathrm{P} / 1$ : Canguaritamba?}

R: Canguaritamba.

$\mathrm{P} / 1$ : E eles se conheceram lá, então?

R: Sim, minha mãe tinha origem em outra cidade vizinha, mas já morava com a tia em Canguaritamba, e daí, chegou eu nesse mundo de Deus, uma situação um pouco adversa, né, porque meu pai na época tinha dinheiro, e tudo podia, e podia mesmo, e até de encontro aos valores, assim de, constituir uma segunda família, e enfim, nós vivemos a vida inteira em harmonia com essa situação.

$\mathrm{P} / 1$ : $\mathrm{E}$ você chegou a conhecer o engenho?

R: Eu cheguei a conhecer o engenho muito pouco, já fui conhecer depois de grande, não é, porque como nós éramos, assim, a segunda família, a minha mãe com todo orgulho era a outra, e a gente não tinha muito acesso a essa parte da vida da outra do meu pai.

$\mathrm{P} / 1$ : $\mathrm{E}$ você tem irmãos?

$\mathrm{R}$ : Nós somos cinco irmãos, e nasceram sete e dois morreram, porque era na época que se morria muito, né, a mortalidade infantil era incrível, então, por melhor que fosse a situação, ainda e morreram dois, ficamos cinco, dois homens, três homens e duas mulheres.

$\mathrm{P} / 1$ :E vocês cresceram lá em Canguaritamba?

R: Até os cinco anos de idade eu vivi em Canguaritamba, e depois o meu pai resol- 
veu nos levar pra capital, para ter uma condição melhor de estudo, assim era o que passava para gente, e eu não quis vir, eu fiquei ainda um tempo, não lembro exatamente, mas eu acredito que uns dois anos com uma segunda mãe que era uma avó, que não era avó, mas que me viu nascer e me pegou da mão da parteira, e me teve a vida inteira muito carinho, e eu fiquei na cidadezinha, e foi lá mesmo que eu aprendi a escrever, e aprendi muita coisa da vida, porque nessa idade até sete anos, é uma idade muito importante.

$\mathrm{P} /-\mathrm{E}$ como é que era você lembra? Em Canguaritamba?

$\mathrm{P} / 1$ : Era uma cidade pequena, como toda cidade do interior, tinha lá a igreja, a escolinha, a delegacia, e eu lembro muito pouco porque, eu quando sai de lá, tinha menos que sete anos, oito anos, oito anos por ai, de 64, oito anos de idade.

$\mathrm{P} / 1$ : Mas você lembra-se de alguma coisa que você gostava de comer, com sua segunda mãe, com sua mãe?

$\mathrm{R}$ : Ah, ela fazia uma comidinha gostosa, fava, ela chamava de raposa de fava, ela amassava a fava, fava, nossa, é um tipo de feijão, então, ela amassava, assim, com a mão, e amassava e misturava com a carnezinha, a mistura, não é, e me dava aquele bolinho, a raposa, e isso é o que me vem na memória das delicias que eu saboreava das mãos da minha avozinha.

P/1: E quando você foi pra Natal, como é que foi, seus pais já estavam lá?

R: Já, ai a minha mãe, todo mundo em Natal, e minha mãe, manda o menino, e manda o menino, e eu fui a pulso, porque eu não queria ir, né, eu tinha uma afinidade com a avozinha, e fui, e enfim, como lá eu terminei de me criar.

$\mathrm{P} / 1$ : Em Canguaritamba, você morava na cidade?

R: Em Canguaritamba sim, eu morava na cidade, em Natal também já fomos morar lá no bairro, no mesmo bairro que até hoje moro, que é o bairro do Alecrim.

$\mathrm{P} / 1$ : É uma casa? E como é essa casa?

R: É uma casa simples, né, é uma casa simples.

$\mathrm{P} / 1$ : E a sua casa da infância você lembra, se Lea tinha quintal?

R: A casa da infância, eu voltei outros dias depois, e sonhava muito com meus irmãos, vamos comprar essa casa de volta, vamos comprar essa casa de volta, porque trazia 
muitas recordações do tempo, tinha um sítio em torno da casa, cajueiro, eu lembro de um cajueiro formidável, que eu acredito que, aos cinco anos, o meu presente, o meu bolo foi ter encontrado um caju enorme, todo inteirinho sem estar mordido dos pássaros, né, bicada dos pássaros, nem de morcego, e aquele caju, eu lembro que foi uma alegria muito grande para mim, que não tinha bolos pra comem orar aniversários, e aquele caju nós fatiamos, e ali fizemos a brincadeira no dia do meu aniversario, e eu fiquei muito satisfeito, porque foi um grande presente pra mim, aquele caju.

$\mathrm{P} / 1$ : Tinha outras frutas também?

R: Tinha jaqueira, tinha pitombeira, tinha mangueira, tinha varias frutas, frutas que normalmente sustentam o nordestino.

$\mathrm{P} / 1$ : E como é que era, você dividia o quarto com seus irmãos, sua mãe ficava em casa?

R: Minha mãe ali sempre em casa, e eu dividia sim, quartos com meus irmãos, dormíamos em rede, e tinha o quarto das crianças, não era, é uma casa que tem o quarto de cada um, ou pelo menos, o dos homens e das mulheres, na minha infância todo mundo alinhado ali juntinho.

$\mathrm{P} / 1$ : Vocês iam começar a ir pra escola, você aprendeu a ler e escrever em Canguaritamba? Mas em Natal, você começou a ir pra escola?

R: Em Natal sim, eu graças a Deus, eu tive sempre muita vontade de estudar, porque já foi uma anunciação da minha avozinha, ela me levava na escola, ela me tomava a lição, ela me orientava, então, eu acredito que foi um grande impulso para mim gostar de aprender, né, gostar de estudar, eu ia para a escola, dava duas lições, tinha que dar uma lição, uma pagina dum livrinho, ela me preparava tanto que eu dava as duas, aquela leitura meia decorada, daquela cartilha, daí pra frente, Natal, eu tomei gosto pelo estudo, e teve uma época que a situação nossa era difícil, eu sou filho de escola pública, com dificuldade, teve uma fase brava, tinha fase que a alimentação da manhã, ia ser a merenda da escola, e eu sempre gostei e fui estudando, e graças a Deus, chequei até uma faculdade, e fiz um curso superior, e estou aprendendo, já estou querendo estudar mais, tinha uma promessa,ai, dum mestrado, alguma coisa, não sei como vou fazer com o meu tempo para.

$\mathrm{P} / 1$ : Você é o irmão mais novo, do meio?

R: Eu sou o irmão do meio.

$\mathrm{P} / 1$ : E quando vocês iam para escola, quando vocês eram pequenos, vocês iam juntos, lá em Natal, como era isso, vocês acordavam?

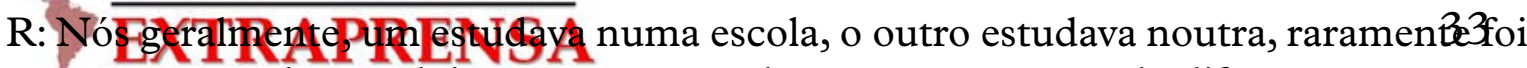
o ano que estudou os dois na mesma escola, mas era uma escola diferente. 


\section{$\mathrm{P} / 1$ : Por quê?}

$\mathrm{R}$ : Porque era conveniência, às vezes da série, a questão de vaga, ia ficando tudo, mas tinha as escolas todas próximas.

$\mathrm{P} / 1$ : E sua mãe levavam vocês pra escola, ou iam sozinhos?

R: Não, lá no interior, lá na cidadezinha onde minha avó, ás vezes, eu estava manhoso demais para ir, ela ia me deixar, levava até no braço, e eu já na cidade, na capital, ai nós já estávamos também, já crescidos, né, em torno de dez anos, de treze, quatorze, ai já íamos aos deslocando para a escola.

$\mathrm{P} / 1$ : $\mathrm{E}$, às vezes, para almoçar, assim, depois que voltavam da escola, sua mãe fazia o almoço?

$\mathrm{R}$ : Ai sim, na volta, mas lá em casa a gente sempre tinha uma coisa, nunca reunia formalmente na hora da refeição, todo mundo não, um chegava mais antecipado, almoçava, outro chegava depois, já almoçava, ficava sempre flexível, minha mãe que sofria bastante, pra dar conta da refeição, desencontradas, cada um.

$\mathrm{P} / 1$ : Seus pais mudaram pra Natal, por causa do trabalho?

R: É, eles nos trouxe pra Natal, porque como eu falei, quer nos dar uma educação melhor, quer dar uma educação melhor, ai trouxe pra Natal, pra Capital.

P/1: Chegou em Natal, ele trabalhou?

R: Ele trabalhou, trabalhava na arrecadação, porque ele, na arrecadação fiscal, ele andava pelos estados e regiões, para desenvolver esse trabalho, e nós como éramos de família dividida, meu pai tinha uma outra casa e aminha mãe era a, nós éramos a segunda família, nós não tivemos a presença do pai muito constante, ele passava três dias lá, três dias cá, viajava pra essas cidades.

P/1: Sua mãe que ficava mais.

R: Minha mãe que foi mais presente na minha vida.

$\mathrm{P} / 1$ : E ela teve muitos amigos, lá em Natal?

R: Sim, minha mãe como eu falei, no momento difícil de sua vida, assim, ela costurava, chama na minha cidade, costurar pra fora, costurar pra fora era fazer costura sobre medidas para as pessoas, e eu até ajudava, a máquina não tinha motor, e ás vezes, 
ela cansava o pé, de pedalar aquela maquina, e eu ficava ali fazendo o movimento do pedal para a costura seguir.

$\mathrm{P} / 1$ : Já dava uma ajuda?

R: Já dava uma ajuda, sentado embaixo, sentado perto dos pés dela.

$\mathrm{P} / 1$ : Você brincava muito com seus irmãos?

R: Nós tivemos uma infância de brincadeira, sim, nós andávamos, nós íamos para o rio, Rio Potandí, nós jogávamos bola na rua, tinha campo, tinha espaço, não é mais como hoje, com a urbanização, ai foram destruindo todos aqueles espaços que nós tínhamos, nós tínhamos vários campos de futebol, em torno da casa do bairro, a rua não era pavimentada, era areia, na frente de casa mesmo se fazia, improvisada um campo de futebol, hoje a gente pra jogar futebol tem que pagar, alugar, escolinha, colocar os filhos numa escolinha de futebol, mas naquele tempo era bem melhor.

\section{$\mathrm{P} / 1$ : Não tinha prédios também, né?}

R: É, não tinha prédios, era uma casa até afastado da outra, aquele bairro que eu moro hoje, ele se urbanizar, ao longo desse tempo, de uma forma até brutal, eu continuo morando na rua que sempre m orei, moro a mais de quarenta anos nessa rua.

\section{$\mathrm{P} / 1$ : Como chama?}

R: Rua dos Canídeos, é o nome de uma tribo de índio da nossa região, e eu fiquei, ficou essa rua até hoje, e sem coragem de largar aquele ambiente, que foi me acostumando, com assim, com essa parafernália toda da urbanização, uma conveniência, hoje nós estendemos o braço e já tem um supermercado pra que a gente compre alguma coisa, estende outro braço tem uma farmácia, e ai mais do ládo, a feira, a escola, o posto de saúde, é tudo muito próximo, mas ficou muito desumana, agitação, muitos carros, um lugar movimentado, um lugar municipais, era o trânsito, a poluição sonora, é a falta de espaço com os meninos, meu filho hoje fica numa calçada onde os carros tão passando a três metros de distância, quanto a velocidade, como a gente se preocupa mas não pode deixar preso dentro de casa, tem a violência urbana que chegou, ninguém pode dormir com a porta aberta como se fazia, na época chegava em casa e ficava até a madrugada dormindo no vento, na brisa da calçada, hoje a gente vai chegando em casa fica preocupado, com o que pode estar esperando na entrada de casa. É uma coisa triste, essa realidade da urbanização.

$\mathrm{P} / 1$ - Quando o senhor era novo, você já via assim, na rua lá em Natal, lá na sua cidade de infância você já via festas populares, aulas de capoeira? 
R: É, olha uma das coisas que me encantou quando começou época de carnaval, passava as escolas de samba, tribos indígenas, isso me cantava né, certa vez eu falei pra minha mãe, minha mãe eu quero um dia ficar dentro de um tambor desses, com eles batendo comigo dentro e, interessante, foi uma primeira impressão, primeira vontade que eu tive quando vi uma charanga de samba passar com aquela batucada toda, foi dizer isso, e quero ficar dentro de um tambor desses para eles baterem comigo dentro, até que, no ano vi passar também junto com o pessoal da escola de samba, um pessoal com berimbau de capoeira, e eu fui, sabia que era brincadeira de jogar com as pernas e tudo mais, uma luta ai, fiquei com muita vontade de aprender, e pedi, depois eu fui, tive amizade com o rapaz do amigo da escola, filho do Mestre da escola de samba e pedi para que se ele pudesse me ensinar, porque eu gostaria de aprender a capoeira, e ele Fernando Geles, ele ah ensino, ele ia lá pra casa, pro quintal lá de casa, embaixo de uma mangueira e ali nós, ele ficava passando os passos,os gingados e outra hora também eu ia para casa dele, ai fui entrando no terreno da escola de samba, também se aproximava o carnaval, vinha os ensaios e dentro desse fundamento de ensaio também, ele vivia me passando as gingas de capoeira e de lá pra cá eu não abandonei mas a capoeira.

$\mathrm{P} / 1$ - Você tinha quantos anos mais ou menos?

R: Eu tinha já 13, 14 anos.

$\mathrm{P} / 1$ : Deve ter sido bacana ter visto vários berimbaus, assim, brincando?

R: Era sim os berimbaus, mas o legal mesmo foi que eu entrei na capoeira e depois que entrei, aí não consegui me afastar mais, comecei a me dedicar, a entender como poderia fazer o berimbau, a cuidar do berimbau, que o pessoal já não cuidava muito, pegava de qualquer jeito pra tocar na hora que se reunia, e eu comecei a me preocupar de fazer o berimbau, de consertar, de melhorar.

P/1: Isso na Angola, já?

R: Isso não, nós não sabíamos ainda, nem que capoeira era, a origem dessa capoeira era mais até da regional, porque Natal tem um porto e uma escola de aprendiz de marinheiro, e muita gente de Salvador, do Rio de Janeiro, e que conhecia a capoeira e gostava de samba, e nessa escola deixou uma semente de capoeira, e é até mais da linhagem da capoeira regional, a Angola, eu fui tendo os primeiros contatos através de um livro, um disco do Mestre Caiçara, um vinil, um disco LP do Mestre Caiçara, e com isso, tinha também o vinil do Mestre Bimba, ai ali a gente ia exercitando os toques e tentando entender que diferença tinha essa, só depois de cinco anos de capoeira, é que eu comecei a viajar para Salvador, no sentido de encontrar respos- 
tas para muitas coisas que eu gostaria de saber sobre a capoeira, e como Salvador, a Bahia é um celeiro de grandes Mestres de capoeira, é lá que surge o movimento da capoeiragem que saiu para os Estados e para o mundo, então, eu comecei a viajar pra Salvador, para conhecer o Mestre de Capoeira, e ai foi que me, deu de encontro com uma figura fantástica na capoeiragem, e como ser humano, conheci já cego, já no final da vida, já não jogava mais capoeira, mas que trouxe a luz, o caminho, pra vida e pra capoeira, eu conheci um Mestre Pastinha, Vicente Ferreira Pastinha, então, isso para mim é de um tamanho incrível, para a vida e para capoeira.

\section{$\mathrm{P} / 1$ : Conta para a gente, como foi esse encontro?}

$\mathrm{R}$ : Nos primeiros anos que eu fui, eu já tinha um disco que também apareceu de um Mestre Pastinha, um disco feito em 69, onde ele relata, fala da experiência dele de capoeira, e eu achava que ele já tinha morrido, achava que já tinha morrido, e nessas idas para Salvador, eu conheci o Mestre Camafeu de Oxossi, conheci os primeiros Mestres, depois os Mestres Caiçara, e quando eu perguntava sobre o Pastinha, eles diziam, ah o Pastinha acabou, e quando eles diziam, o Mestre Pastinha acabou, eu achava que era no sentido de ter morrido, ter morrido, mas eu, acabou, que pena, mas eu continuei, continuei andando, conhecendo Mestres, e foi outro ano, e só em $75,76,75,76$ é que, eu sempre fui uma pessoa que deu muito valor as pessoas que andam na rua, sarjeta, que por acaso, esta numa situação social de decadência, porque independente dos aspectos que elas tenham, elas tem uma lição de vida e tem uma história para contar, e ás vezes, tem uma cultura enorme para passar, e veja bem como as coisas acontecem, não é? Eu vinha no Penhorinho, subindo a ladeira e vinha descendo um bêbado meio que cambaleando, e eu se pondo na frente dele, de repente eu pergunto, e o Mestre Pastinha? E eu não sei por que perguntei, eu só perguntei, e o Mestre Pastinha? E ele parou, deu aquela sobriedade e disse no meu olho, o senhor vai aqui no 14, e ai, nossa, e eu me arrepiei e sempre choro quando lembro disso, desculpa. E ai ele, o senhor vai ai no 14, e nós, eu subi e ele desceu, e eu fui direto no 14, quero número 14, da Rua Alfredo Brito, e chegando lá tinha uma loja de artesanato na frente, com um a arcada de um casarão, na sala de entrada e tinha improvisado, pregado nas paredes, artesanato, bolsa, sandália, cintos e couro, e eu, bom é 14 . E eu fui entrando, e quando mais adentro eu percebi que no fundo, tinha uma porta que se abria, e uma vida de casas, de quartos, que moravam pessoas humildes, e logo nos primeiros quartos, que era um quarto embaixo de um teto de madeira que era a parte de cima do sobrado, e ai já estava aquele velhinho lá, de cabeça branca, num banquinho tosco de madeira antiga, velha, envelhecido, do tempo e uma baiana na mesa ao ládo, mexendo uma massa de acarajé, e eu falei, bom dia! Eu sou do Rio Grande do Norte, e eu estou procurando conhecer o Mestre Pastinha, e ela responde assim, atende dessa forma, a já chegou mais um aproveitador para usar, usufruir, roubar o que o Pastinha conhece, depois sai por ai, faz disco, faz livro, diz que é capoeira, e que aprendeu com Mestre Pastinha, e o Mestre Pastinha continua 
aqui na miséria,esse homem esta cego, na miséria, abandonado, eu que o sustento em cima de um tabuleiro de acarajé, ai ela falou uns cinco minutos, e eu querendo falar, mas eu disse, a senhora, qualquer coisa, mas ela não me deixava falar, e xingava filho de uma, e PA, e porque vem aqui, filma, explora, faz reportagem, e vai embora e Pastinha continua aqui na miséria e tal e eu fiquei pasmo, e ela diz, para falar com, ela chamava-se Dona Nice, Nice Romelia, ela passou a viver com Mestre Pastinha, depois que o Mestre começou a cegar, ele chegou de glaucoma e catarata, então, ela tinha banca de acarajé embaixo da academia, que é o Centro Esportivo de Capoeira, que ele fundou, desde muito tempo, no primeiro andar e que esse, enfim, quando começou a ficar cego, ele cegou, ela passou a conviver e a cuidar dele, e cuidava também de uma forma muito forte, e ela vira depois de ter falado muito, e diz, para falar com Mestre Pastinha é cem cruzeiro a hora, diante daquela revolta que ela tinha, que muita gente procurava e não deixava provavelmente o suficiente para o sustento mais digno do Mestre, e eu falo, e ai não me controlei e cai em pranto, né, eu cai em pranto, soluçando mesmo diante de ter, era uma pessoa que eu já tinha uma referência muito forte por um disco que eu tinha gravado, que ele gravou ali,a voz, a mensagem, o canto, conselho da capoeira, que ainda hoje é uma coisa atual e Serve para os capoeiristas da atualidade ouvir, né, e eu disse, eu fiquei pasmo, cem cruzeiro a hora para falar com Mestre Pastinha, e eu não agüentei, soluçar e disse, olha senhora eu tenho dinheiro para pagar o preço que a senhora esta cobrando, para o Mestre me falar durante cinco horas, depois eu vou para casa a pé, de carona, e robô para voltar, ta bom, e eu faço qualquer coisa, mas não é isso que eu quero não. Eu queria só conhecer o Mestre Pastinha, e estou vendo que é ele que esta aqui, isso entre choro eu falando, e ela quase, ela só se assustou, só parou quando ela me viu descontroladamente chorando, soluçando forte mesmo, aí ela se assusta e me permitiu que eu desse a palavra a ele. E ele bate no banco, ele fala para ela, ta bom, ela quer voltar a falar e ele fala, ta bom e foi um ta bom só e ela calou e ele bateu no banco e falou, sente aqui e aí eu sentei, e ela um silencio profundo, incrível como um ta bom, ele tinha uma história de falar ta bom, e ela calou e ele me perguntou de onde eu vim, sou de Natal, Rio Grande do Norte, o senhor conhece? Não, eu não conheço mas passei perto e o senhor gosta de capoeira? Eu falei gosto, faço, fazem cinco anos e estou aqui na Bahia procurando respostas para algumas coisas que eu quero ter da capoeira e daí para frente, ele falou bastante, e falei eu preciso pagar? Ele falou não senhor, o senhor não vai pagar nada, o senhor não vai pagar por nada e ela ficou calada, a Dona Nice. E eu fiquei, "Meu Deus", foi um momento muito especial para minha vida, foi um momento muito especial e eu fiquei depois, por algum tempo, perguntei para ele, eu posso voltar? Porque eu tinha que perguntar isso, eu estava louco para continuar aquele contato, aquele encontro com ele, e aí ele disse assim, o senhor vem quando o senhor quiser, o senhor vem quando o senhor quiser, aí eu fui no outro dia, voltei, ela me recebe da mesma forma, com muito impacta, já voltou? Olha aí, veio explorar o sossego do Mestre sossegado, descansando, eu disse calma, minha senhora, calma, eu só vim dar uma passadinha aqui para olhar para ele, só vim olhar, não vou falar nada, 
não vou falar nada, não quero ouvir nada, eu quero só ficar aqui um pouquinho, mas ela, ta bom de novo,ele falou ta bom, ela calava e depois eu comecei a entender aquela receptividade que eu tive, porque aquele desaforo todo da parte dela, e entendi que muitos passaram por ali e isso de certa forma, tanto cansava, incomodava, como também havia uma exploração de quem ia buscar alguma coisa pra que, conhecimento de um Mestre, que estava numa situação cega, na miséria, e para ganhar dinheiro, para ganhar a vida, que naquela época já começavam alguns a ganhar dinheiro com capoeira e ele, ela se viu assim, numa missão de protegê-lo, tanto que, num determinado momento desses encontros com Mestre Pastinha, eu falo, pergunto para ele, Mestre, eu não lhe vi jogar, eu quero entender como é esse traçado do jogo, porque eu preciso ver isso também, me dê o nome de uma pessoa que conviveu com o senhor, então ele me deu, ele disse imediatamente, ele me disse, o senhor procura Gildo Alfinete, na Joana Angélica, que é uma avenida próximo lá do pelourinho, em Salvador, eu não contei história, eu fui direto para me encontrar com o Mestre Gildo Alfinete, que era a pessoa que Mestre Pastinha estava me indicando para entender esse jogo e me falar mais algumas coisas da capoeira Angola, da capoeira que ele guardou, da capoeira que ele foi titulado por Jorge Amado e por tantos outros, guardião da capoeira Angola, e eu estar naquele tempo, num manancial de riqueza dessa cultura, corri ao encontro do Mestre Gildo Alfinete, lá na Joana Angélica e me informaram, aqui numa casa lotérica, numa lanchonete que tem aqui do lado, chamei pelo Mestre e ele desceu, e eu disse, Mestre Gildo Alfinete? Ele disse sou eu, eu disse, "eu estou vindo aqui a mando do Mestre Pastinha", olha a emoção que eu estou sentindo, é a emoção de eu ter dito isso e ele ter desmanchado em pranto, em choro, e disse assim, "o que? O velho lembrou de mim?" "Ele que me mandou aqui", "você esteve lá? Mas eu não vou mais lá, aquela mulher já isolou todo mundo, bota todo mundo pra correr, xinga todo mundo", ai eu fui entender que, não foi só comigo, muita gente dali de Salvador, do convívio dele, como foi o Mestre Gildo Alfinete, que conviveu a vida inteira com Mestre Pastinha, tinha ele como um pai, também tinha se afastado de lá, "e você como conseguiu falar com, e aquela mulher?" "Eu disse, ela me xingou muito, mas eu fiquei por, e ele ta bom, pra ela calar" "e daí, ele mandou me procurar?" Emocionado, com a satisfação de ter aquela lembrança por parte do Mestre, "se ele mandou me procurar", ele ficou vaidoso com aquilo, ele ficou vaidoso com aquilo, eu disse mandou sim, quando eu perguntei que precisava conhecer alguém para me dar uma traçado de jogo, porque eu estava conhecendo ele e já cego, e ele disse, procure Gildo Alfinete, na Joana Angélica, aí ele, "não é possível, aquele velho", fala aquele velho, então foi uma coisa muito forte, tanto quanto eu encontrei o Mestre Pastinha, consegui essa aproximação com ele, como, quando ele me manda atrás do Mestre Gildo e a emoção é desse tamanho, e aí depois eu fui entendendo, o Mestre Gildo tem hoje, da certidão de nascimento até o atestado de óbito do Mestre Pastinha, bengalas, panos, poesias, desenhos, manuscritos, instrumentos, registros da Academia, de todos que passaram pela academia, pelo Centro Esportivo de Capoeira Angola, o CECA, criado na década de 40, o Mestre Pastinha foi o primeiro a sair do Brasil, para 
mostrar a capoeira lá no Exterior, na África, no festival de 1966, e o Mestre Gildo foi um dos que acompanharam o Mestre Pastinha, e aí ele me recebeu até hoje, como um irmão, como um irmão, me levou pra cada dele e disse assim, "vou lhe ensinar umas malvadezas", ele disse, "eu estou afastado", ele falou, "não tenho mais nada com capoeira, muita gente aí faz essas besteiras aí e tal e diz que é capoeira, e eu me afastei do Mestre porque aquela mulher não quer ninguém do lado dele, se afastou muita gente, médicos que iam lá para dar uma assistência para o Pastinha, que ele tinha muitos amigos, ninguém vai mais lá porque ela fica desaforando todo mundo, mas eu vou lhe ensinar algumas malvadezas", aí me levou para casa dele e me mostrou tudo que tinha do Mestre Pastinha e me mostrou umas malvadezas, como ele dizia, né, e daí foi um encontro formidável, falar de minha pessoa, eu não posso falar de mim, sem falar do Mestre Pastinha, sem falar dessas coisas que Deus me deu, que Deus me deu, eu tenho uma referência muito grande de meus país, da minha família, mas nenhuma pessoa me influenciou na vida, o quanto Mestre Pastinha, e olhe que eu convivi muito pouco, tive bons professores, nas escolas por onde eu passei, meus pais, muitos amigos, muitas pessoas mais velhas me aconselharam no momento difícil da vida, mas o encontro com Mestre pastinha, não foi só pela capoeira,não, foi pela vida, foi pela vida.

$\mathrm{P} / 1$ : Quantos anos você tinha?

R: Eu tinha 20, 75 me ajuda, eu sou de 50, eu tinha 24 anos, né? 75, 21 anos.

P/1: Qual era as dúvidas que você estava levando, que te fez ir até Salvador, sabe?

R: É energia pura, porque quando a gente entra na capoeira, entra numa arte, numa cultura dessas que recebe de forma de oralidade, e, tudo é energia, né, e a gente sempre tem uma referência que a Bahia é o centro da capoeragem, os capoeiristas de nome na história estão naquela região, o Mestre Pastinha, o Mestre Bimba, Camafeu de Oxossi, Mestre Caiçara, Mestre Valdemar do Berimbau, Mestre Paulo dos Anjos, Gato, Canjiquinha, e tantos outros, e daí fui ao encontro desses Mestres para entender mais, pra se fundamentar, porque na vida dessa cultura dita popular, não é? A gente tem que procurar mesmo os Mestres para ter orientação, quem não teve a sorte de nascer ao ládo de um Mestre e receber dele essas informações, tem mesmo que ir buscá-los onde quer que sejam, porque senão não compreendem, a resposta que eu queria, era resposta de compreensão, mesmo da essência, do por que, de como fazer, de como proceder, de como tratar, da ritualística, né, da religiosidade que tem, que permeia, todas essas informações da capoeira, é um centro também de religiosidade, né, é um centro de religiosidade.

P/1: E como é que tava o seu grupo lá em Natal, antes de você ir pra Salvador? 
R: Antes de ir pra Salvador eu peguei lá na escola de samba e permaneci com a rapaziada na escola de samba e saindo, brincando de Ala de capoeira no carnaval, mas ai eu sentia necessidade de fazer de uma forma mais constante todo dia teria que ser dia de capoeira e comecei a juntar no quintal, no terreiro, os amigos que tavam se oferecendo, me procurando pra ir tomando a ola comigo, né, eu fui um auto-ditada na capoeiragem e fui aprendendo, ensinando e aprendendo com ele, ensinando e aprendendo ao mesmo tempo com eles, com os que eu ensinava, ai formei um grupo de capoeira, Filhos de Zumbi, Filhos de Zumbi, e fui, quando eu fui pra Salvador, pra Bahia, eu disse, olha eu vou atrás de mais informação de capoeira, eu quero mais, eu quero conhecer alguns Mestres e preciso ir pra Salvador pra conhecer mais da capoeiragem e quando eu fui eu chego em Salvador e com esses encontros do Mestre Pastinha, num determinado momento ele me diz, um dos anos a seguinte ele me diz, "o senhor por que não leva um certificado meu, pra ser classificado pra poder classificar", "o senhor falou que não tinha mais nada da academia”, "mais eu tenho", e disse "procura os impressos ai", e me concedeu um certificado que pra mim é mais valioso que o certificado que eu tenho da universidade, nem de longe se aproxima e carteira da academia com carimbo dele em cima da fotografia, assinou, mesmo cego, Vicente Ferreira Pastinha e eu fiquei, é, deslumbrado, meu Deus, guardei com tanto cuidado, "traga a maquina pra fazer a fotografia", por que ele não me deixava registrar nada, nem fotografar, nem gravar e nesse momento ele me oferece o certificado, manda levar as maquinas pra fazer as fotografias, veste seu paletó branco, de linho branco, e me permite fazer a foto ao lado dele, fiz quatro fotos com o Mestre Pastinha, isso pra mim já começava a ser respostas pra muita coisa, eu fui tendo resposta desde o primeiro momento quando encontrei, quando o vi pela primeira vez, eu já fui tendo resposta pra vida, fui tendo resposta pra muita coisa que eu não compreendia, eu não tive mais dúvida que existe uma energia superior suprema que é Deus e ele fazia o tempo todo, essa relação da capoeira com Deus, então ele começava assim, num determinado momento, o Mestre Pastinha me perguntou, o senhor sabe quem é o maior capoeirista? E eu fiquei sem jeito pra resposta, eu disse, é o senhor? E ele disse não, o maior capoeirista é Deus e eu fiquei muito tempo refletindo sobre isso e acho a minha interpretação dentro da história, que quando o capoeirista é a imagem e semelhança do ser supremo, de harmonia, de verdade, de justiça que se chama Deus de qualquer forma que se conceda, Ele é o maior capoeirista e ele ainda cantava assim no seu registro fonográfico, ele cantava então ele tinha sempre essa relação com Deus, maior é Deus, pequeno sou eu, o que eu tenho foi Deus que me deu, o que eu tenho foi Deus que me deu, na roda da capoeira, grande pequeno sou eu, era duma humildade incrível e diz se fazer respeitado então na capoeiragem e eu diante de uma grandeza, de um manancial, de uma riqueza enorme dessa, até hoje cada momento que eu relembro é um ganho que eu tenho na minha vida, é um ganho que eu tenho, depois do Mestre Pastinha, transformou mesmo, ai não tem mais jeito, ai é capoeira, capoeira, e eu queria fazer, é, em curso na universidade, de engenharia, eu escolhi Educação Física por ser mais na área de ajudar alguma coisa e pra colocar a capoei- 
ra por essas escolas, né, eu tenho trabalho no Rio Grande do Norte com a capoeira nas escolas, e a muito custo com a descriminação, que a capoeira sempre foi muito descriminada, perseguida, proibida, todos aqueles que fossem pegos praticando em praça pública Exercício de Destreza Corporal, conhecido por capoeiragem, seria preso, em prisão celular, de dois a seis meses, código penal brasileiro de 1830, 1889, e que por reincidência cometeu o mesmo delito, o mesmo crime será deportado para o presídio da Ilha Grande, era um presídio cruel, né, nacional, se jogava pra ali tudo que fosse mal pra sociedade e os capoeiristas tinham esse estigma, né, de porque veio a libertação, não foi preparado uma sociedade pra acolher esse africano, o escravo agora liberto e virou desocupação, e ele, o sistema, os mais poderosos usavam os capoeiristas pra mata, serviço de capadócio né, comprometer, forçar uma pessoa a votar, a cobrar, então o capoeirista foi utilizado na sociedade pra fins maldosos e terminou virando a capoeira um campo na sociedade e o capoeirista um marginal, perseguido, condenado, mas a capoeira foi resistindo, resistindo, e como forma de resistência cultural esta até hoje pelo mundo a fora, não é bom, abriu a porta das escolas e ai tudo vira uma beleza, é cultura brasileira, é festa, é tradição e permeia hoje pelas escolas do mundo inteiro, né, mas porque resistiu a tudo isso, a muita perseguição e eu na minha época que eu comecei fazer capoeira e saia com o berimbau, minha mãe, depois tinha um gravador que gravava algumas coisas e ia treinar, às vezes não levava o berimbau, levava o gravador, uma fitazinha gravada e minha mãe dizia, meu filho, eu acho tão bom quando você sai com esse gravador, ai eu disse, minha mãe, por quê? É porque ai ninguém sabe o que vai dentro, porque era feio e era perigoso sai com o berimbau porque ia fazer a capoeira né, coisa de negro, coisa de malandro e enfim, e as escolas por onde eu passei, as portas fechadas foram muitas, eu comecei a ensinar a Educação Física no ensino público e quando eu me propus a ensinar capoeira e fazer uma experiência com capoeira, sem cobrar nada, sem colocar na minha carga horária, e era uma coisa voluntária, a resposta foi que eu não pode, por que eu não posso? Eu sou professor da escola. Não, porque nós só trabalhamos com esporte olímpico, voleibol, basquetebol.

$\mathrm{P} / 2$ : E quando era isso?

R: Isso foi em 1977, o meu coordenador de área de esportes só pode trabalhar com esporte olímpico.

P/1: O seu Marcos, pra gente aproveitar enquanto ta chovendo um pouquinho, me fala uma coisa, como você foi convidado como Mestre da capoeira, assim, pra entrar como o Mestre Griô.

R: Bom, a cultura desse país sofre um momento de revolução, a idéia dos pontos de cultura, a idéia dos Mestres de valorização da cultura popular dos Griôs, e é um momento muito importante e nós fizemos uma proposta de ponto de cultura que 
foi aprovado e dentro desses pontos de cultura, o ministério da cultura, veio a Ação Griô, e a capoeira começa a participar de uma forma mais digna, de uma forma mais consolidada dentro do movimento social, em busca de contribuir para a educação com uma expressão cultural de identidade, de raiz, não é, de brasilidade e que foi, e a minha participação como Mestre de capoeira, dentro dessas atividades do ponto de cultura tem me dado muita satisfação, porque a gente percebe que o valor desse trabalho que sempre foi feito pelos Mestres de capoeira, construindo o país com seus saberes, com sua cultura, com seus conhecimentos, com seus ensinamentos, não é, vem agora pra dentro de uma formalidade e de um reconhecimento muito grande, então, a oportunidade de participar desse trabalho ponto de cultura, Ação Griô, tem sido de grande satisfação.

\section{$\mathrm{P} / 1$ : Conta pra gente, por que do nome do ponto de cultura lá de Natal?}

R: De Conexão Felipe Camarão, é, o ponto de cultura Felipe Camarão, ele tem um nascimento em torno de dois Mestres de cultura popular que tem uma comunidade que chama-se Felipe Camarão e onde o índice de desenvolvimento humano é baixíssimo, a criminalidade altíssima, prostituição infantil, é, drogas, gravidez precoce, todos os males desses dentro de uma comunidade que só era vista até então nas paginas policiais, então nós fomos querendo fazer uma ação social, de uma forma de instituição civil organizada e criamos uma ONG e fomos pra Felipe Camarão e já tínhamos conhecimento, já, conhecíamos o Mestre Manuel Marinheiro do Boi de Reis, e o Mestre Chico Daniel do Momo lego, do Teatro de Bonecos, que chama Momo lego, e fomos criar junto com eles uma forma que essa cultura fosse conhecida por Felipe Camarão, que era muito mais conhecida fora de Felipe Camarão, fora da comunidade, ai veio o nome de, tornar com essas, fazer com esses dois Mestres uma conexão com a comunidade, então Conexão Felipe Camarão, uma conexão de cultura, de vida, de sabedoria, que vi desses dois Mestres conhecido nacionalmente pelo seu trabalho por arte mas que não eram reconhecidos, nem vistos pela sua comunidade e ai foi surgindo a proposta do ponto de cultura Conexão Felipe Camarão e o Boi de Reis também vai agregando outras manifestações culturais da comunidade e que tem aceitação desses jovens, como a capoeira, percussão, a partir daí se cria uma luteria de rabeca porque a rabeca é um referencial dentro do Boi de Reis e precisavase repassar, construir, se difundir a pratica da execução musical que vinha do Boi de Reis, ai os meninos hoje tão fazendo rebeca, outros tão tocando, outros tão aprendendo flauta por que muita gente através da flauta faz um link com a cultura indígena que é importante também na ancestralidade daquela comunidade que houve tribos indígenas antes naquela comunidade e que tudo isso tinha se perdido através do tempo e o projeto Conexão, o nome vem disso ai, a intenção de fazer uma conexão dos Mestres com os jovens através dessa cultura que eles fizeram a vida inteira.

$\mathrm{P} / 1$ : E fala pra mim, o que você acha que é importante nessa tradição oral que esta 
sendo passada, que ta sendo trabalhada?

R: O importante é essa forma como se dá impulso, a velocidade, a transmissão desse saber, através duma modernidade, de uma nova tecnologia, de uma nova metodologia, que não só a oralidade, que não só a oralidade, hoje a oralidade não começa a ser só oralidade por que a gente já pega todas as informações que vêm de um mestre joga em rede, na internet, como é a idéia dos pontos de cultura e vai ser democratizado essas informações, não é, vai ser oferecida mais rápido e mais facilmente para todos os acessos as informações, então a oralidade teve uma importância muito grande até agora, o que deve-se ter cuidado é com a entrada de novas tecnologias e novas formas de transmissão desses conhecimentos não se iniba, não vêm inibir a oralidade porque é na oralidade, é na presença do mestre como eu relatei que realmente a gente vai sentir a essência do fazer daquela formula, é, vendo e olhando, é nesse contato corpo a corpo com os mestres que a gente entende melhor, não vai ser através do livro nem de uma tecnologia moderna também só.

\section{P/1: A gente estava falando de tradição oral, né?}

R: A tradição oral, esse momento da cultura popular é muito importante, os pontos de cultura, a Ação Griô, né, e eu dizia a utilização de novas tecnologias, de uma sistematização para levar adiante a transmissão oral, não é, porque ai, a gente vai utilizar de varias formas de conhecimentos também, conhecimentos acadêmicos, para que essa tradição de já melhor passada para as outras gerações, agora eu vinha refletindo alguns momentos sobre isso e me tocou um medo, porque o medo é de que, quando se avançar tanto na inclusão de novas tecnologias, para transmitir dos conhecimentos da oralidade, e eles comecem a perder a ciência, e é lógico também que perde a essência, né, pela própria oralidade, essas informações perdem a essências, porque o Mestre passa para um discípulo, aquele vai passar para o outro, e as informações vão perdendo a sua essência, a sua fundamentação, sua verdade, nessa corrente, então, quem, esta lá no final da linha, já começa a ter essa informação distorcida, né, è aquela brincadeira do telefone que vai passando de pessoa para pessoa, já ouviu falar? Eu lhe dou um recado, e diz assim, olha você diga para a pessoa tal que isso vai acontecer de tal forma, a tal hora, que ela precisa de roupa azul, que é para poder combinar com o dia que vai ser de sol, e você passa de uma pessoa, passa para outra pessoa, daqui a dez pessoas que vai receber essa mensagem, vai estar tudo trocado, disse olha ás dez horas o dia esta escuro, e a cor preta do vestido, começa a destorcer tudo, porque a informação, a oralidade, ela perde também sua essência, quando ela vai passando d um para o outro, e é até normal, porque também perde pelo movimento, pelo talão de mudança que sofre a cultura, com as épocas, com os novos tempos, novas gerações, o medo que eu venho sentindo é que o Mestre e onde esta mais verdadeira essas informações, não fique também muito, termina-se sendo mais excluído do processo, porque tem novas tecnologias e pessoas que entendem uma mitologia mais sofis- 
ticada para transmitir esse saber, aí eu vejo um pouco cautela nisso, ta certo? Tipo assim, os Mestres, os Griôs, e os aprendizes de Griôs, e se coloca ao foco, muito forte nos aprendizes de Griôs, eles são animadores culturais, são formidáveis, a proposta é formidável, a proposta é tornar o jovem um elemento que vai conduzir a sabedoria dos Mestres, é formidável a idéia, o risco é que quando forem se, acontecendo mais Griôs, e os Mestres fiquem um pouco mais excluídos do processo, e eu acho que até numa situação que não pode se reverter, porque já os Mestres já não vão atender a uma demanda tão grande de pessoas que querem essa informação, mas não há mal nisso, não há mal nisso não.

\section{$\mathrm{P} / 1$ : Porque dai ele pode ficar um pouco mais afastado, né?}

R: Ele mais afastado, isso é uma volta, porque é uma volta e cai na mesma ponta da roda que começou, que girava, né. Os Mestres estavam esquecidos, desvalorizados, eles agora tem um valor, ressaltados, camados, aclamados e valorizados, mas aí vão sendo formando um valor também na corrente da transmissão através de outras pessoas, e aí vai embora o conhecimento dele e ele vai ficar aqui, não é?

\section{$\mathrm{P} / 1$ : Tem um cuidado com respeito à ancestralidade, né?}

R: É um cuidado com respeito à ancestralidade.

P/1: E me conta uma coisa, Mestre, como você passa o seu conhecimento para os mais jovens?

R: Olha, esse mesmo problema, o que acontece na capoeira? Eu estou aqui, eu recebo do Mestre Pastinha que recebeu de Benedito, um negro africano, ex-escravo. Olha um menino com oito anos de idade conhece o Mestre Pastinha, o Mestre Pastinha viu o menino apanhar de um garoto, lá embaixo, de cima de um sobrado, aí chamou e disse: "olha você não pode com aquele garoto, porque ele é mais esperto que você, invés de você empinar picula, raia, jogar picula, empinar raia, você vem pra aqui pra gente fuzuar, que eu vou lhe ensinar a fuzuar", era uma brincadeira diante da capoeira, para ele ficar mais dresto, mais esperto e tal, e ai com oito anos, o Mestre Pastinha foi ao Benedito e ensinou umas coisas, dai o Mestre já deu uma lição no menino, o Pastinha já pegou o menino e lá vem o menino com a mãe, ele contando essa história, a mãe do menino disse, olha lá aquele garoto, olha agora que você vai ver, não agora você vai ver como que você vai apanhar, a própria mãe aí, aí o menino vai e cata ele de uma lado, ele sai pelo outro, mostra para um lado, ele vai, já não era mais aquele garoto fácil de ser, dai ele da uma lição no menino, né, e ele conta a história, e isto, você me perguntava, como que eu passo? Aí eu recebo do Mestre Pastinha, fiquei satisfeito por ter ido, por ter conhecido o Mestre Pastinha, porque se eu ficasse na distancia, eu não teria entendido muita coisa, eu tinha um disco gravado 
com a voz dele. Capoeirista não deve provocar, capoeirista não deve fazer perto das coisas, no meu tempo eu era capoeirista e contava as histórias, o maior é Deus, e vai, ai foi diferente quando eu conheci o Mestre, ai não precisou mais ele falar, só a presença do Mestre já traz para a gente uma energia e uma compreensão daquilo que o Mestre ensina, daquilo que o Mestre faz, aí você começa a ouvir na voz, uma atitude diante daquilo que ele faz, então essa relação direta com o Mestre é muito importante. Eu quando eu recebo esse pouco que sei de capoeira, o pouco que eu aprendi com o Mestre Pastinha, ensino para um aluno, e o aluno se torna um professor, e vai abrindo outros núcleos de capoeira, é assim que funciona nas comunidades, então, quando eu me aproximo, ai o aluno dele já esta dando aula, aluno do meu aluno, eu já tenho netos e bisnetos de capoeira, ta certo? Eu tenho netos e bisnetos de capoeira, e quando eu visito as comunidades, quando eu recebo do Mestre e passo para os alunos, eu já tenho esses bisnetos de capoeira, e que eu chego nas comunidades, quando eles estão dando aula, que me aproximo da criança que esta ali recebendo aquele conhecimento, eu já vejo que esta tudo torto, mas o que foi que houve?Aí chama o, puxa rapaz, você não esta vendo isso? Olha aí, eles estão descarreirando nesse toque, os meninos não estão indo ao pé do berimbau para fazer a ritualística, reverência ao berimbau, cumprimentar o colega, eles não se abraçam quando termina o jogo, não é? Eles estão alucinados, eletrizados pelo esse jeito louco dessa geração, que esta aí, internet da vida, dos games, dos jogos das lan houses, não sei de que das quantas, da violência urbana, e esta, quando eu vejo a violência urbana esta instalada dentro da roda da capoeira, mas eu digo, mas se a gente já tem que controlar essa situação, mas Mestre é porque, então vamos, quer dizer, esse desdobramento da transmissão oral, ele corre o risco de se perder, a esse, é preciso se descobrir também uma forma de inserir aos registros, como esse, como talvez no pouco que eu conheço, eu esteja deixando uma contribuição muito pequena, para que se entenda essas relações do Mestre, aquele que foi buscar nas origens, que também, foi que todo mundo, tudo se transforma, né? O tempo vai mudando vai se transformando, mas a gente deve ter esse cuidado de ver a essência. O que, ás vezes, a modernidade, a gente vem tratando, modernidade e tradição, o que é modernidade hoje pode ser a tradição de amanhã, daqui a 300 anos. Olha, a tradição é que se sente o mestre e que se faça um registro de vídeo de um Mestre, para ele dar a sua história de vida, e ficar aí para as outras gerações absorver, isso é tradicional dentro dessa cultura, não é? Uma coisa que vocês estão trazendo agora, como um momento de modernidade e isso depois a tradição, $o$ Mestre Pastinha colocou dentro da capoeira dele, uma roupa, a calça preta e a camisa amarela, que era do time que ele torcia, time do coração, que era o time do Ipiranga, e até então, se sabia que o capoeirista, se houvesse que ser uma roupa que caracterizasse o capoeirista, era um terno de linho branco, um chapéu de pano amar, um chinelo de chadim que chamava, uma coisa assim, a calça larga, de boca larga que saia por ali e tal, e branco, de branco, que jogava não se sujava e tal, e ainda hoje é tradicionalmente na capoeira essa forma de jogar de roupa branca, de não se sujar, de não deixar o chapéu cair, de ser cordial com o colega, impecável no tratamento do corpo, mas a 
tradição e a modernidade, a tradição oral.

\section{$\mathrm{P} / 1$ : 15 segundinhos.}

R: Nós falávamos na tradição oral, falávamos no valor que ela tem, eu vou aproveitar para cantar uma ladainha que fala justamente desses valores e da chegada desses valores aos mais jovens. "Quilombola quer justiça, Quilombola quer justiça e os direitos iguais, da o vôo da liberdade, lá no campo da paz. Seus avós e bisavós já padeceram demais. O quilombo goleiro quer cantar nesse local, falando de amor e paz e justiça social, sem amor não ha justiça, sem paz o amor padece pra fortalecer os três, a capoeira aparece, o Mestre de fundamento usa a capoeira Angola para melhorar a vida dos alunos na escola, neutralizando os conflitos que tem na sociedade, abre bem os olhos dos jovens e mostrando a realidade, que o amor é a arma de luta de lutar pela liberdade, amar é viver, viva meu Deus, e viva meu Deus camarada". E são essas coisa que a escola da capoeira, através da oralidade se manteve viva e traz como uma forte contribuição, sempre deu essa contribuição para a sociedade Brasileira, sempre deu, ela foi proibida, quase extinta, violentada mesmo nesse processo que é, por qual passou o povo brasileiro, a formação do povo brasileiro, ela tem construindo, construindo, construiu até guerreiros pra ir para guerra do Paraguai, imagine isso, então os capoeiristas que foram enviados para a guerra do Paraguai, se destacaram por atos de bravuras e voltaram pra receber alforria, porque tinha se destacado no combate lá, na guerra, mas não é pela guerra mais é pela paz que a capoeira deve entrar na sociedade e é pela paz, é como, é como cultura de paz, ela deve ser implantada disseminada entre os jovens, e a gente vê que a capoeira tem muito praia, pra isso, a capoeira cooperação, é solidariedade, é respeito, é amizade, camaradagem, é ritualístico que é fé, compleição, a capoeira angola dizia ao mestre pastinha, é infinita, olha só o que ele dizia, capoeira angola é infinita, é tudo que a boca come, capoeira angola é capoeira mãe, se o principio não tem método, seu fim é inconcebível ao mais sacro capoeirista, é mandinga de escravo em ânsia de liberdade, então nesse aspecto de que ela foi formada, essa ânsia de liberdade, de uma fome espontânea, sem sistematização sem método, nós chegamos a conceber hoje que o fim é inconcebível, a gente não tem fim, ela tem volta, ela é como uma roda, ela vai girando e vai voltando as origens, vai voltando as origens que é pra não se perder.

$\mathrm{P} / 1$ : É, só voltando um pouquinho assim no, na sua família, conta um pouquinho que sua esposa, seus filhos, como é que é?

R: Ah, hoje eu sou casado, tenho uma esposa maravilhosa, entendo que a família é a célula principal do ser humano e tenho dois filhos, são capoeirista porque querem ser capoeirista, não que eu tenha obrigado, eles caminharam pela capoeira, opção deles e nem chamam, não gostam de chamar, não gostam de forçar que eles aprendem capoeira, e que seja natural, né, que seja mais pro meu exemplo, se agrada, eles seguem 
e graças a Deus eles estão vindo ai, faz capoeira.

P/1: Qual que é o nome deles?

R: Eu, é o Marcos Antônio, Marquinhos e o João de Deus, João de Deus já ta dando aula de capoeira, já me substitui, precisa aprender muita coisa também, que hoje estou aprendendo, né, imagina ele mais dez.

$\mathrm{P} / 1$ : E sua esposa, o nome dela?

R: Minha esposa, Cilene, Cilene Ferreira de Carvalho.

P/1: Hum, fala uma coisa além do ponto de cultura, do trabalho que você esta fazendo na escola e o que mais você anda fazendo lá em Natal? Você tem uma escola também?

R: É, não, eu não tenho uma escola de capoeirão como chama academia, eu tenho um grupo que, mas que se discadersou o trabalho a partir das escolas públicas e de projetos sociais, onde esses meninos e essa garotada que vão se formando professor de capoeira, vão multiplicando esse saber e vão dentro de suas comunidades participando de projetos sociais, do voluntariado e ai enfim, é, eu sou professor da rede pública, estadual e municipal e também particular.

\section{$\mathrm{P} / 1$ : De Educação Física?}

R: De educação física, mas eu mexo graças a Deus mais com educação física, eu mexo com educação física brasileira, o esporte de identidade cultural, nacional, que é a capoeiragem, que é o jogo da capoeira, então é com o jogo da capoeira que eu atendo todas as necessidades na área de educação física, é que demorou muito, porque a educação física no Brasil sempre foi uma grande importação de valores e de cultura, de formação de métodos estrangeiros que vinham da França, da Áustria enfim, e, e a capoeira sempre foi a verdadeira ginástica nacional. Não é, porque temos que elogiar. Tem a peteca do Índio, coisa maravilhosa que é a cavalhada, a vaquejada, e jogos populares, as danças de roda, tanta coisa que, é uma riqueza enorme nesse país, nessa cultura pra se tornar recreação e educação física do povo brasileiro, mas...

P/1: Mas que bacana essa idéia de mudar a Educação Física, né? Mudar ela de como ela é dada geralmente, para colocar a coisa brasileira mesmo, né?

R: É, mas ainda não esta como devia ser porque alguns conceitos formados, os professores ainda estudam muito a questão técnica dos esportes formais, dos esportes que tem nível, dos esportes olímpicos como falava no começo da conversa, eu tentava 
colocar capoeira na escola e o coordenador de educação física disse, não, não pode, por quê? Porque não é esporte olímpico, e nós só podemos trabalhar na escola com esporte olímpico, eu sai chorando e disse para ele, então eu vou esperar que ela seja esporte olímpico um dia para poder trabalhar na escola, e aí caminhei por conta própria de forma clandestina, de forma clandestina nas escolas, assim que ela entrou, na clandestinidade, pela comunidade, os meninos vão ali e jogam uma capoeira acolá, aí o professor não entende nada daquilo, né, não sabe que exercício usa. Vai tomando conta, ai hoje quando um grupo grande, olha, a gente quer botar capoeira aqui na escola, e a escola, no mínimo a escola já da um espaço ali, costumo até dizer que na maioria dos casos, ela usa o espaço da escola, mas não esta na escola, porque ela não interage com tudo que ela tem para dar na formação da cidadania, na formação integral da criança, do jovem, do adolescente, ela não, em muitos casos, as experiências também que estão acontecendo maravilhosamente, respeitosamente, e essa capoeira pode contribuir da melhor forma possível, não é? Porque é tão rica, é dança, é luta, é brincadeira, é jogo de corpo, é teatro, são verdadeiros palcos livre de teatro de forma de expressão ou de, com gestos corporais, você vai ter que responder as perguntas que eu lhe fizer, e eu respondi as que você me faz, com gestos de entra, de sai, de sobe, desce, joga o braço, sai para o ládo, sai para outro, e eu ia interpretando, que papel você esta fazendo? Ta maldoso, ta maldicioso, quer me pegar aqui ou ali, esta me mandando eu ir para um canto que não devo ir, olha, ta me armando armadilha, $\mathrm{e}$ nessa linguagem, esse é um verdadeiro teatro, não é? É arte plástica, é teatro, é poesia, é música, a musicalidade da capoeira, a escola da música da capoeira fez surgir os melhores percussionistas do mundo, que são os brasileiros, Nana Vasconcelos, Bino Nascimento, Papete, e vários outros aí, que fizeram do berimbau o seu instrumento para percorrer o mundo, viagem nas Américas, na Europa, tocando com orquestra sinfônica, fica com um berimbau na mão,berimbau da capoeira, da escola da capoeira, então, é música pura, interessante, a gente tem que valorizar isso aí.

$\mathrm{P} / 1$ - Mas Marcos, essa diversidade toda do Brasil. A gente esta aqui no encontro da Ação Griô, que junta três estados, Alagoas, Rio Grande do Norte e Pernambuco, como que o senhor se sente participando desse encontro, assim, desse caldo todo?

R: Formidável, é um aprendizado incrível, a gente percebe cada vez mais, que a gente tem mais que receber do que aprender, do que ensinar. Tem muito mais que aprender do que ensinar, o que a gente ensina é muito pouco, o que a gente esta aprendendo na vida é bem mais, a gente não consegue ensinar, enfim, educar aprendendo com quem a gente educa, a gente não tem a pretensão as vezes de educar alguém. Mas na verdade a gente se educa enquanto educa, é uma troca, e aqui é um momento especial, é um momento que se discute e se preocupa com essas questões, e tenta se encontrar numa metodologia, como falei, que de velocidade a transmissão oral, unida a velocidade com respeito, com respeito a quem de direito de fato, não de direito que nunca teve mesmo, o Mestre da tradição oral, foi de fato, o grande mantenedor dessa viva 
cultura brasileira, mas nunca foi tão respeitado quanto agora, nunca foi tão respeitado quanto agora. E eu fico, e volto a falar daquele medo que eu falava anterior, eu volto a dizer que tenho um medo em que isso vai embora o conhecimento desses mestres, na mão de Griôs e de aprendiz de griôs e tudo mais, e que os mestres fiquem novamente caindo no esquecimento, né, e que não seja também motivados a surgimento de outros mestres, tão rápido quanto rápido vai ser o crescimento e o aparecimento de pessoas que vão intermediar essa transmissão. Não é, porque a urbanização nos centros urbanos, o mestre já não atende todos, os mestres já são poucos pra demanda que tem, que consome sua arte, não é verdade? Os mestres de cultura popular já começou ser pouco, antigamente tinha um lugarzinho e tinha um mestre ali, curandeiro, um mestre alfaiate e até um mestre carpinteiro, um mestre capoeirão, enfim, mas agora ha uma necessidade, há um crescimento populacional maior e o surgimento de novos mestres, me parece que fica muito pouco na dimensão do crescimento da demanda, que esses mestres teriam para deixar sua contribuição, né, como é que pode fazer surgir um mestre? A gente aprende na capoeira que é a vida que faz um mestre, não um diploma de doutor, é a vida que faz o mestre. E parece ser um processo tão natural o surgimento dessas pessoas, desses mestres, que façam por paixão alguma arte, e na verdade é mais demorado o surgimento deles, né, é bem mais rápido do surgimento do mestre acadêmico. Então você faz uma graduação e mais dois anos, você é mestre, né, é doutor naquele conhecimento, é mais rápido, vai, a universidade vai botando produção em série, os mestres do conhecimento acadêmico, produção em série. Ah se pudesse ser produção em série também, os mestres do conhecimento popular, aí já é uma grande desvantagem. O que permeia mais nas pessoas, é o conhecimento acadêmico ou o que vem dos mestres, de formação acadêmica ou dos mestres de cultura popular? É bem mais nas academias, que são maiores, que dominam mais as tecnologias, nas formas de transmitir e são mais valorizados, porque comercialmente, mas as coisas acontecem e estão acontecendo, então, essa oportunidade de estar aqui no Encontro Ação Griô, nessa proposta metodológica, junto aos pontos de cultura, junto com essa grande tecido cultural da iniciativa do Ministério da Cultura e desse governo, porque nunca governo nenhum, chegou nem de perto a se preocupar com as coisas do povo, a valorização dessa cultura, quem se preocupava era os mestres do conhecimento acadêmico, de formação acadêmica, que procuravam os mestres de sabedoria popular, os mestres da oralidade para tirar dele algumas contribuições para suas teses, para suas pesquisas, para seus laboratórios de medicinas, né, convencional, iam buscar no popular a receita certa para já entrar para o laboratório, saber qual erva vai prestar pra que, daí a industria registrava um patente de uma erva tal, o tal, e daí você não poder mais nem usar o chá, porque já vai ser patenteado pela uma indústria que, os mestres do conhecimento científico, acadêmico, né, buscaram lá no, porque no científico não seria nada se não fosse o conhecimento popular, eles tem mesmo é que devolver pra camada, pro popular, pra esses núcleos de informações que ele tirou, alguma coisa que ele pudesse ter melhorado por sua ciência, e realmente melhorar mesmo, né, porque ás vezes, ele pega um, uma matéria que é para remédio e 
termina achando melhor fazer daquilo um concentrado para envenenar, não é assim? Em vez de usar como remédio, porque tem, no popular tem, dizem que remédio demais é veneno e veneno pouco é remédio, né, então, ás vezes, as pesquisas científicas traz um conhecimento popular, uma forma de matar, mais do que dar vida.

P/1- Seu Marcos, a gente vai chegando ao fim, eu queria que você ficasse à vontade para falar mais um pouco dessa história, alguma coisa que você queira, né, fica à vontade, e queria que depois você dissesse um pouco também, o que você achou dessa experiência de estar contando um pouquinho da sua historia para o museu, ta?

R: Eu vou começar pela experiência e depois.

$\mathrm{P} / 1$ : Fica à vontade, se quiser cantar.

R: Vou entrar pela despedida, né, então é formidável, viu? Isso aqui é o verdadeiro divã de psicanálise. A gente, faz um retrospecto na vida da gente, e de uma forma digna porque a gente sabe que esta fazendo uma retrospectiva e esta deixando alguma semente, para que alguém tome como exemplo, tenha, tome como lição de vida, não é, encontre uma informação, siga adiante pela vida, e a gente aqui sente dessa forma, isso é a sensação que eu estou tendo, sabe, é uma situação de permanência, de imortalidade, né, a gente sente mais imortal, porque é mais um registro com uma intenção forte de preservação da memória mesmo, desse povo todo, e que a gente sente de uma importância incrível, eu vou sair daqui renovado e, e fico mesmo lisonjeado, encabulado, porque vocês ficam querendo tirar da gente o que a gente tem,porque depois a gente vai achando que esta tendo coisa demais, ai a gente se acha, sabe?Grande, mas aí pra se lembrar do canto do mestre, grande e pequeno sou eu, e caminhar, né, e para encerrar o que eu poderia dizer? Cantar?

\section{$\mathrm{P} / 1$ : Fala alguma coisa, sobre teus sonhos, o que você pensa agora para frente?}

R: O grande sonho da minha vida é ver o mundo de paz, de paz, os dias que estou aqui junto com essa natureza, a gente vê como a gente ainda tem, como a gente ainda tem paz, e que a natureza sofra menos com as nossas agressões, né, mas vamos nos corrigindo, e o homem pode viver melhor se entender melhor a natureza, e a minha esperança é que realmente isso aconteça. $\mathrm{E}$ que as pessoas venham por esse mundo de Deus, com mais harmonia, mais compreensão, mais paz mesmo, e vocês estejam todos com Deus, e Deus proteja todos nós, nas suas varias formas de entendimento, que seja as forças da natureza, dos Orixás, dos Santos, dos Devotos, dos Beatos, dos Curandeiros, as Almas, de qualquer forma que seja, que canais de Deus em nós, e que nós mesmos compreenda esses, sejamos mais um canal para expressar o Criador, né, Criatura e Criador, sejam a essência da criação mesmo, essa relação, que eu vou encerrar tocando um pouquinho. "Adeus, Adeus, boa viagem vou embora, boa 
viagem e vou com Deus, boa viagem Nossa Senhora,boa viagem, boa viagem eu vou me embora, boa viagem eu vou com Deus, boa viagem Nossa Senhora, boa viagem, Adeus".

$\mathrm{P} / 1$ : Só uma última perguntinha curiosa, o que significa os anéis?

R: Há uma simbologia, um som na capoeira, você vê que tudo que vem da cultura popular uma ritualística, né, eu gosto muito de simbologia e sou de certa forma esotérico, eu pertenço a um grupo de estudos, chama-se Círculos Esotéricos da Comunhão do Pensamento, e acredito que o pensamento é uma grande ferramenta para que a gente encontre mais espiritualidade, mais compreensão de si mesmo e da natureza e esses anéis é um símbolo de Salomão, uma estrela de seis pontas que simbolizam o equilíbrio, diz que o que esta embaixo é como que esta em cima, o triangulo que aponta para cima é um triangulo que representa o corpo espiritual, a energia, o que aponta para baixo é o que é mais terra, mais matéria, e que eles entrelaçados, eles simbolizam um equilíbrio do corpo físico e do corpo espiritual, isso é basicamente essa simbologia, aí falam que é uma grande proteção, o símbolo de Salomão, a estrela de seis pontas, porque essa proteção? Porque quando a gente esta nesse equilíbrio de energias, a gente esta protegido, só isso já é uma proteção, e se quiser desdobrar essa proteção por mais algumas compreensões e que o símbolo vai se desdobrando na sua apresentação, a outra estrela, dizem que seria o protetor dos capoeiristas, o sinbolo de Salomão ele permeia no candomblé, na Umbanda, e muito ritualística da estrela, então muita gente usa esse hexagrama como um pingente, ás vezes, não compreende bem o que representa, é tão comum, não é? O pentagrama, esse símbolo, ele representa, é uma estrela de cinco pontas e representa o homem, nessa forma o homem com suas faculdades morais, intelectuais do bem, do bem, das forças do bem, ele de ponta cabeça ele seria a representação do homem com suas faculdades morais distorcidas e desviadas, e de uma forma mais satânica, vamos dizer, mais uma forma mais redivisada do homem, ele de ponta invertida e se usa os rituais para um tratamento de sua forma, ele em sua posição mais de cabeça, então a cada cabeça, braço, perna tem umas representações de um magnético, de força, de atração, harmonia, vontade, e aí vai, eu gosto de simbologia por isso eu uso.

\section{$\mathrm{P} / 1$ : E o chapéu?}

R: O chapéu é uma proteção mesmo assim, tradicionalmente na cultura do Brasil, da capoeiragem, protege do sol, não é, protege do sol, e o chapéu de certa forma guarda, guarda, tem uma simbologia também, a cabeça da gente, então você fica aqui meio que protegido, que guardado, então você põe o chapéu aqui, você se guarda, protege, hoje com os raios solares ai esta trazendo câncer de pele, tudo também é útil, né, é pratico, a utilização do chapéu, eu uso chapéu, sempre gostei de chapéu, é mas, eu sempre tive medo porque eu percebia, ele também aquece muito a raiz do cabelo, aí 
cai, aí eu uso mais eventualmente, né, não uso muito constante.

$\mathrm{P} / 1$ : Outra coisa que eu vejo sempre com você é o seu berimbau.

R: O berimbau é minha ferramenta de trabalho, né, você vê que eu vim para a entrevista, eu não consegui me desligar, digo eu posso usar o berimbau, porque a gente toca o berimbau as coisa espairece, durante muito tempo na minha vida eu começava o dia tocando berimbau e jogando capoeira religiosamente, de manhã cedo pegava o berimbau, da o toque, porque quando a gente toca o berimbau, a gente vai tentando encontrar uma vibração nesse toque, numa determinada situações que a gente se encontra, como é na capoeira, quando toca Angola, o jogo é lento, manhoso, mais ativo, bem mais para a luta, e aí tem outro, quando toca a ulna, ai o jogo é informado, de veste, onde eles te respeitam mais, tocam e conduz de uma forma mais minuciosa, mais ritualizada, e o berimbau tem isso, né,a gente com o berimbau, hoje, antigamente os capoeiristas estavam armados para as horas de necessidade de confusão,porque aqui eles usavam, desmontavam o berimbau, encaixava aqui uma foice, e aí ia manejar, mais hoje já não precisa, esse pontiagudo aqui, antigamente ele era pontiagudo mesmo, porque também servia de arma, aí hoje já é um instrumento musical, não precisa mais, paz mesmo, a gente tem que buscar a paz, né, aí o berimbau da, ferramenta de trabalho, e expressa através do som, o berimbau, o mestre controla de certa forma as pessoas com quem eles estão trabalhando $\mathrm{n}$ a roda de capoeira, aí eu sempre que, o motivo que me trouxe estar aqui como mestre de cultura popular dentro do Movimento Ação Griô, foi por ser mestre de capoeira, então o berimbau não pode se afastar de mim.

\section{$\mathrm{P} / 1$ : Você que fez esse?}

R: É, eu que faço meus berimbaus, eu confecciono, o berimbau, o caxixe, esse foi um amigo que faz, ele tem mais tempo, então eu já estou comprando mais direto pra ele, e é muito bem feito, o caxixe, mas o berimbau eu faço questão, ás vezes, eu deixo os meninos fazendo, mas eu quero pegar, eu fico deixa eu ver o tempo todo, sentindo aonde, como é que ele vai ficar no final, né, porque é importante demais o berimbau, a gente diz que o berimbau é o grande mestre da roda de capoeira, ele recebe a energia, do que eu costumo dizer, que nós não fazemos a capoeira, a capoeira existe já, e nós só somos canais de fazer essa capoeira acontecer, e ela chega até nós através de que é, da facilidade de vir através da música que o berimbau traz, então o tocador de berimbau, se ele é de fundamento, se ele conhece, ele com certeza, ele vai facilitar essa sintonia de quem joga com a capoeira que é uma, que é maior que a gente, nós somos só uma forma de expressar a capoeira, da capoeira se fazer, se materializar, mas a capoeira já existe e independente de nós, e o berimbau tem essa importância, ás vezes, eu saio com o berimbau nem uso, nem usei, mas eu saio com o berimbau. 
P/1: A gente do Museu da Pessoa gostaria de agradecer muito, foi um grande prazer ter escutado um pouquinho da sua história, e que a Ação Griô, que os Mestres, que os pontos de cultura sejam sempre respeitados e que continuar o trabalho.

R: Muito obrigado, viu? Eu que agradeço a vocês pela oportunidade, vocês me fizeram muito bem, aquilo que eu falei, é uma terapia, eu estou fortalecido pela minha caminhada pela vida, muito obrigado e que Deus abençoe a todos vocês.

$\mathrm{P} / 1$ : Obrigada.

\section{Depoimento de José Bernardo Pessoa - Mestre Zé Duda Entrevistado por: Winny Choe e Julia Basso Local: Piaçá do Sul, 06 de outubro de 2007 Realização: Museu da Pessoa Transcrito por: Maria da Conceição Amaral da Silva}

P/1: Seu Zé Duda, para começar eu queria que o senhor falasse o seu nome completo, e a cidade que o senhor nasceu.

R: Meu nome completo é José Bernardo Pessoa. Agora, o pessoal só me conhece por Zé Duda. E nasci em uma cidadezinha pequena do interior por nome Buenos Aires. Mas essa não é Buenos Aires lá de fora, é daqui do interior mesmo. Fica depois de Nazaré. Lugar que eu nasci. Nasci e saí de lá com 17 anos. Aí ganhei o meio do mundo.

$\mathrm{P} / 1$ : Como é que foi, você tem irmãos? Qual é o nome dos seus pais?

R: Tenho sim. O meu pai é Severino Bernardo Pessoa, minha mãe Eulália Malaquias. E irmão eu tenho quatro. Agora, vive mais eu somente uma irmã. O resto vive tudo pelo mundo.

$\mathrm{P} / 1$ : $\mathrm{E}$ como é que foi a sua infância em Buenos Aires? Conta um pouquinho para gente?

R: A minha infância em Buenos Aires foi para mim foi muito boa. No começo até que eu pensei que não. Mas graças a Deus, quem pensa em Deus tudo tem. Sempre eu tive o sonho de alguma coisa. Eu nunca saía de casa porque eu era privado, a minha mãe não deixava. Nesse tempo os filhos respeitava os pai. Hoje em dia não. Filho diz: "Vou para tal canto." E vai e vai mesmo, acabou. Mas eu fui criado em um tempo que se a minha mãe dissesse, não, meu pai dissesse: "Vai", minha mãe dissesse: "Não vai", 
eu não ia. Ela quebrava a ordem do meu pai. Porque ele dava a autorização de eu ir, ela não deixava. Aí eu não ia. Então eu fui criado nesse tempo. Me deram o tempo para estudar, eu não quis. Não quis. Lutaram para mim estudar, eu digo: "Eu não quero aprender ler." "O que é que você quer?" Eu digo: "Eu não quero nada." Foi depois botei na cabeça de acompanhar maracatu. Mas ela não deixava eu sair de casa para ir olhar maracatu. Mas um dia e teve um maracatu distante da minha casa e eu fui dormir. Quando eu acordei uma faixa de 10 horas da noite eu vi tocando, a zuada pelo mundo. Aí escutei assim dentro de casa, eles tudo dormindo, meu pai. Eu abri a porta devagarzinho, saí, fechei, joguei a chave por baixo, fui embora. Quando eu chego no maracatu estava dois mestres sambando. Cheguei entre um e outro fiquei. $\mathrm{E}$ ali só saí quando terminaram de manhã. Quando terminaram de manhã, de os dois não, mas de um eu sabia tudinho o que ele tinha cantado. Eu decorei tudinho no juízo. Eles se despediram foram embora. Um para um canto, outro para outro. E eu fui embora para casa. Quando eu cheguei em casa estava tudo brabo me procurando, porque eu não estava em casa. A rede estava armada mas eu não estava. Aí me procurando, aí vou chegando. Já com medo de apanhar. Porque a véia era malvada para mim. "Você estava aonde?" Eu digo: "Eu estava no maracatu." "Sozinho?" Eu digo: "Não, estava meio mundo de gente e eu estava no meio." "Isso é bonito?" Eu digo: "É bonito e eu sei cantar." Aí disse: "Sabe nada, meu filho." Eu digo: "Eu sei, eu sei cantar." E fiquei com aquilo no juízo: "Eu sei cantar o maracatu." Pela tarde lá nesse lugar ia ter maracatu novamente. Tomei um banho, tomei um cafezinho, me deitei mas não pude dormir, choqueado. Pedindo a Deus que chegasse meio-dia para eu ir para lá. E pedindo a Deus ela deixar eu ir. Eu já saí escondido, e agora possa ser que ela não deixe eu ir. Mas o meu pai, eu gostava demais do meu pai, pedi a ele: "Pai, deixa eu ir." Ele disse: "Eu quebro o galho, vá-se embora." Quando eu fui saindo ela me freiou: "Prá onde?" Eu digo: "Eu vou para o maracatu." Ela disse: "Ó o dedinho." "O pai deixou." Ele disse: "Vá.” Eu disse: "Graças a Deus, meu Deus.” Eu fui embora. Quando cheguei lá aí estava os dois maracatu travado. No lugar que eu nasci ninguém nunca tinha visto eu cantar, nadinha. Eu disse: "Olha, se eu for cantar maracatu, eu canto.” A turma: “Mas tu canta nada, rapaz. Tu nunca visse maracatu, pirralho. E como é que tu canta maracatu?" Eu digo: "Eu canto." Ansioso para cantar. Aí vai, botaram um tamborete, eu me subi, que eu era pequeno assim. Subi no tamborete, cantei maracatu até a hora de terminar. Cantei o que eu decorei do cara eu cantei todinho, que o mestre ele não sabia, foi uma valha para ele. Aí a turma caiu em cima. Caiu em cima: "Tem um menino sambando maracatu, e logo na rua." Aí o bicho pegou. Tinha um sargento lá na cidade, ele era muito encapetado. Se o cara soubesse cantar ciranda, maracatu, cavalo-marinho, coco-de-roda, coco-de-pandeiro, ele chamava. Não tinha dia. Podia ser segunda, terça, quarta, qualquer dia. Aí ele disse: "Eu vou fazer um maracatu para você." Eu digo: "Graças a Deus." Realizei porque o sargento que vai fazer. Ele arrumou um bombo lá, um terno de maracatu e eu comecei brincando. E fui ensaiando com o mestre, sambando com os outros mestres: pá, pá, pá, pá, depois passei a pronto. Quando eu passei a pronto eu digo: “Agora eu não 
tenho medo de mestre não. Agora é pé de parede mais eles. Seja o que seja." O cara que eu aprendi com ele, escutei, ele não sabia que eu tinha aprendido tudinho que ele tinha cantado. Eu disse: "E agora? Eu com os outros posso cantar, mas com ele eu não posso cantar o que aprendi dele. Porque possa ser que se eu cantar com ele, ele diz: 'Isso aí é meu' - realmente ele podia dizer o quanto eu posso fazer com qualquer um - ‘isso aí é meu'.” Aí eu digo: “O que é que eu faço? É fazer para mim. - eu digo agora eu vou ver se o meu juízo dá." Botei o juízo para funcionar e foi a maior tranqüilidade para mim. Eu segurei o baque. Segurei o baque e aí no dia que eu completei 10 anos meu presente de aniversário foi eu tirar um carnaval. Maracatu. O cara me entregou o maracatu pronto. 36 caboclo, acompanhado. Bonito todo. Aí disse: "O mestre é você." Eu desse tamanho. Que eu com 10 anos era do tamanho de jumento, pequeno. Tirei o maracatu. Fiquei ansioso. Quando eu, a minha mãe não queria deixar eu tirar o maracatu porque ia passar três dias fora de casa. $\mathrm{O}$ dono do maracatu muito jeitoso, e coisa, aí tirou eu da unha dela. Quando eu saí no domingo de oito horas do dia de casa, cheguei na quarta. Quando eu cheguei em casa ela disse: "Gostou?" Eu disse: "Gostei." Ela disse: "Foi o primeiro e o derradeiro que você brincou." Eu falei: "Por quê? Eu não morri." Ela disse: "Porque eu não quero que você brinque.” Eu disse: "Meu pai do céu, meu Jesus, dá-lhe no juízo dela para ela deixar eu brincar." Aí o pessoal caiu para cima dela: "Dona Eulália, deixa o seu filho brincar. É um signo que ele trouxe e ninguém pode cortar." A minha de umbigo, cortou meu umbigo quando eu nasci, aí: "Comadre, deixa ele brincar." Mas comadre, eu não quero porque maracatu é uma tuia de pau, uma tuia de homem bravo, e vai matar meu filho", não sei o que. Mas eu dizia: "E a senhora de filho só tem eu? Não tem seis filhos?" "Não, mas você é o mais desmantelado para ganhar mundo. Mas tudo bem, eu vou ver quem pode mais, se é você ou é eu." Eu disse: “O que é que ela quer fazer, meu Deus?” Depois de Carpina, tem um lugar chamado Pau d'alho. É uma cidade chamada Pau d'alho e tem uma igreja de um santo chamado São Severino. Todo mundo se vale desse santo. Ela que fez. Foi e fez uma promessa para São Severino para eu deixar de brincar. Mas que lá em casa, casa de taipa, a parede era capaz de ninguém ver a parede. Toda qualidade de retrato de santo tinha. Então tinha São Severino. Ela tramou tudinho, fez a promessa e foi pagar. Saiu de casa no domingo quatro horas da manhã. Quando eu acordei de manhã e procurei por ela, não encontrei. Perguntei ao meu pai: "Quedê ela?" Ele disse: "Foi para São Severino.” Eu falei: "Espera aí, ver o que?" Ele disse: "Não sei." Aí peguei a interrogar ele. "Mas o senhor deve saber." Realmente ele não sabia. Ela fez essa promessa e foi, mas não disse a ele sobre o que. Porque ele apoiava. Ele apoiava. Meu pai não bebia, meu pai não jogava, meu pai não fumava. O meu pai era tranqüilo. Como pobre, mas era tranqüilo. Então eu tinha todo apoio do meu pai. Eu, com 7 anos, só dormia, só ia para a minha rede quando ele se deitasse no chão em uma esteira para eu me deitar para dormir um sono em cima do estomago dele. Com 7 anos. Às vezes eu pegava no sono, ele me pegava levava para a minha rede. De tão amoroso que eu era a meu pai. Aí quando ela chegou pela tarde, dei a bença a ela. Ela trouxe um bocado de negócio para mim, 
para me tapear. Um bocado de bala, um pacote de bala, uns confeito grande assim. Bolo de goma. Trouxe um bocado de coisa, aí me entregou. Mas deixa que eu estava com o coração desse tamanho assim. Louco para saber o que ela tinha ido fazer. Eu falei para ela: "A senhora foi para onde?" Ela disse: "Fui para São Severino mais comadre Nana, dar um passeio, que eu só vivo em casa no roçado e coisa." Fiquei nervoso. Eu disse: "A senhora foi para São Severino, e esse santo aqui é qual?” Ela disse: "É São Severino." Aí meu pai disse até uma piada. Meu pai disse: "Meu filho, santo de casa é corno." Eu falei: "Por que santo de casa é corno, meu pai?" Ele disse: "Ela foi para São Severino, e esse aqui que você está mostrando não é São Severino? Se ela tinha alguma devoção fazia com esse aqui, não ia para lá não.” Eu até brincando disse a meu pai: "Porque lá é a fonte, meu pai. Acho que aonde nasceu São Severino, eu acho que é a fonte. Então é mais poderoso do que esse aqui. E quando foi no outro dia, ela disse a lá um pessoal: "Eu fiz uma promessa para São Severino e ele vai deixar de brincar." Aí o cara correu por trás e me disse: "Digo, agora e não diz que fui eu que disse." Botei as duas mãos na cabeça e comecei chorar: "Meu Deus do céu." São Severino é muito forte. $\mathrm{O}$ que o pessoal pedia a ele via, né? $\mathrm{E}$ ela fazer uma promessa dessa e irão me parar? Aí eu comecei a chorar escondido. Aqui, acolá, estava chorando. O povo perguntava: “O que é que tem Zé Duda?" "Nada não.” Mas a língua engrossava porque eu não podia dizer o que era. E lá vem se aproximando o sábado, e eu tinha um ensaio de maracatu com outro mestre para dar no sábado. Então eu disse: "Agora eu vou ver.” Quando chegou a sexta-feira, eu disse: "Agora eu vou ver.” Aí o pessoal que brincava comigo: "Como é, a gente vai ou não vai?" Eu digo: "Vai." O pessoal tudo sabia. Eu fui. Quando cheguei lá sambei a noite todinha. Nada faltou no meu juízo. Quando foi no outro sábado, de novo. Eu disse: “Agora eu vou dar o pagamento a ela da promessa que ela fez. Apesar que eu sou muito devoto de São Severino também, mas eu vou dar o pagamento a ela." Fui sambar com outro mestre, ela foi. Chegou lá eu comecei cantar e coisa, e o povo admirando. O povo admirava eu cantar porque eu era muito pequeno, mas era encapetado que só uma cebola. Aí comecei a cantar e coisa, e ela lá. Com uma toalha grande enrolada no pescoço. Aí chegou bem perto de mim. Eu fiz um samba para ela. Eu disse: "Mamãe fez uma promessa para eu deixar de sambar. Abalando todo mundo conquistando o pessoal. Ralando o joelho pelo chão, só para me atrapalhar. Quando ela foi no altar chorando e acendendo vela. E o santo foi, gritou: 'velha deixe seu filho vadiar'." Ela botou a mão para cima e disparou no choro. Não pode me parar não. Aí eu disse: "Tá vendo quem tem fé em Deus o que é que faz? Agora, a senhora não pode me bater, e nem São Severino. Porque a senhora é devota dele e eu sou também. A senhora tem fé nele para parar de eu brincar, e eu tenho fé nele para ele aumentar para eu brincar.” Aí ela liberou. Liberou e eu toquei a vida até hoje. Disse: "Se prestar eu fico, se não prestar eu saio.” Que pena que eu já fiz 58 carnaval, agora em 2007. Agora eu estou pedindo ao pessoal lá onde eu brinco para ver se eu chegou brincando 2008, 2009. Se eu brincar esses dois anos aí eu já falei com todo mundo para fazer o aniversário. 60 carnaval e 70 anos de idade. Aí eu deixo um no meu lugar e saio do brinquedo. Aí a turma não 
fica. "O dono do brinquedo quero ver como é que fica." O dono do brinquedo disse, o dono só não, todo mundo, produtor, tudo. Aí disse: "Ainda você não podendo brincar, mas que você só sais desse brinquedo quando Jesus levar. Porque se você não puder andar, no carnaval a gente aluga um carro, os carro do maracatu na frente, você atrás em um carrinho porque foi você que deu a vida a esse maracatu." para melhor eu fui brincar nesse maracatu um ano. Tirar o primeiro carnaval. Saí brincando em todos os maracatu: pá, pá, pá, mas teve um de eu chegar e ficar. É esse que eu estou. Quando eu cheguei nele, olhei a cara do dono assim, ele disse: "Você vai brincar comigo?" Eu disse: "Vou não." Ele disse: "Porque você não vai brincar comigo?" Eu digo: "Porque eu não fui com a sua cara." "Espera aí, o que é que tem o maracatu com a minha cara?" Eu digo: "Porque o que eu tenho de dizer eu não mando ninguém, eu mesmo digo. Porque se eu disser duas palavras, e se eu mandar dizer o cara diz dez." Mas apesar que só disse duas. Talvez se eu disser: 'diga a Batista que eu vou.' São duas palavras. Aí o cara diz: 'Zé Duda mandou dizer, seu Batista, que não vinha, e pá, pá, pá.' Faz dez. São doze. Então eu estou logo lhe dizendo: ‘eu não vou tirar seu maracatu não porque eu não fui com a sua cara'." Ele disse: "Mas por que assim?" Eu digo: "Porque eu estou sabendo do povo aí que o senhor gosta muito de gritar o povo do seu brinquedo. Eu fui criado com um homem que não sabia gritar ninguém. E outra, que eu soube do senhor: qualquer coisa o senhor dá no cara. O cara que me criou me deixou, foi embora eu fiquei com 17 anos, ele nunca tocou em mim. Porque se um cara tocar em mim se eu não pegar ele na hora eu pego ele depois. Mas de me vingar eu me vingo." Ele foi e disse: “Zé Duda.” Eu disse: "Senhor.” Ele disse: "Como é que você sabe que um comer é bom se você não comer?" Eu digo: "Realmente é mesmo." Eu até disse uma piada a ele, eu disse: "Eu vou enfrentar que eu só digo que o bicho é macho quando eu capo." Ele disse: "Vamos brincar?" Que brincar foi esse que eu já fiz 38 carnaval nesse maracatu? 38 anos eu estou nesse maracatu. Brinquei com ele, ele faleceu, o filho tomou conta. Eu deixei, fui-me embora, passei cinco anos fora do maracatu. O filho tomou conta, foi me buscar eu voltei. Fiz 38 anos nesse maracatu. Não tenho intrigado, não tenho um inimigo. $\mathrm{E}$ já rodei muito lugar com esse maracatu. Tenho grande conhecimento. Também eu sei plantar e sei colher. Porque a onde a gente encontra flores, flores. Se a gente encontrar espinho é espinho. Mas se a gente encontrar flores, como é que eu não posso maltratar vocês que me tratam tão bem? É isso que o povo é apegado comigo. "Zé Duda, eu preciso disso eu lhe ajudo, posso ajudar?" "Pode." "Então eu vou ver se ajudo. Quando eu disser: "Não posso." é porque não posso. Não tento porque não dá para mim. Então esse sofrimento da minha vida, eu tenho uma grande felicidade, que eu digo: "O cara sofreu na vida." eu não, eu não sofri na vida. Porque eu tive tempo para estudar, eu tive tempo para tudo, mas depois que eu botei a cara na cultura eu não troco estudo. Tem muita gente formada, formatura: "Mas Zé Duda, tu estava aonde?" "Eu estava em São Paulo." "Estava aonde, Zé Duda?" "Eu estava no Rio." "Estava aonde, ZÉ Duda?" "Eu estava em Brasília." "Estava aonde?” "Estava em Belo Horizonte." "Estava aonde?" "Estava lá em Paris." "Zé Duda, estava em Paris?” "Estava em Paris.” 
"Não acredito.” Eu digo: “Ó o comprovante.” E, hoje em dia tudo o que eu tenho foi através da cultura. Que a minha mãe disse, voltar ao assunto da minha mãe. Minha mãe só queria que eu trabalhasse na roça, no roçado. Eu trabalhava, mas aquilo não tinha futuro, não tinha futuro. Ela dizia: "Meu filho, maracatu não tem futuro." Eu disse: "Mas talvez tenha. Talvez tenha. Talvez a senhora ainda vá usar produto do maracatu." Ela disse: "Isso eu vou pagar para ver." Hoje em dia não passo como um deboche, mas foi, não foi, ela sentada assim eu passo na cara dela. E disse: "Ainda é de vim tempo de a senhora morar em um canto e eu morar noutro. Distante um do outro. Não estou com orgulho e nem jogando uma praga à senhora não. Eu estou acordando a senhora, que a senhora dorme. A senhora morar em um canto e eu noutro. Aí a senhora vem de viagem, há de perguntar: 'quem mora ali??' 'quem mora ali é um tal de Zé Duda.' E a senhora saber que é seu filho." Ela disse: "Isso nunca chega, meu filho. Não chega não, porque você é muito preguiçoso. Você só quer estar andando pelo mundo, trabalhando de porteiro, de portador, em cima de caminhão. E você nunca chega a isso que você quer não." Eu disse: "Vamos dar tempo ao tempo. Quem sabe é aquele dali, não é a gente. Eu estou fazendo a planta, vamos ver se ele água. Se ele aguar, gera.” Aí foi dito e feito. E eu comecei, comecei, comecei, quando ela não esperava eu me desapartei dela. Desapartei dela. Ela foi para um canto eu fui para outro. Ela comprou uma casa, morava em casa alugada, aí comprou uma casinha. Mandou me chamar lá. Eu fui. Eu cheguei lá, ela casou novamente. Quando eu cheguei lá ela disse: "Essa casa é sua, essa casa é sua. Agora eu quero que você faça uma para mim atrás no quintal, que o quintal é grande." Eu digo: "Não quero não." "Mas por que não quer? Estou the dando uma casa e você não quer?" Eu digo: "Não quero não. Não é soberba, é porque não quero." eu disse: "Era isso?" Ela falou: "É." Eu disse: "Vou embora." Ela disse: "Não, deixe para ir amanhã." Eu passei o dia lá com ela, dormi, no outro dia fui embora.

\section{$\mathrm{P} / 1$ : Isso foi com quantos anos?}

R: Já estava maduro, já. Foi agora em 88 . Eu já tinha rodado o mundo. Uhh, tudinho. Porque esses tempo que eu tenho no maracatu, eu morava lá na casa do dono do maracatu. Ele tinha umas casas lá, ele tinha 18 casas. Eu morava em uma não pagava renda. Porque o encabulado do cara é pagar aluguel de casa, porque ele paga agora e já está devendo de novo. Aí, foi, foi, foi, comecei dar uns roda pelo mundo. Comecei andar para São Paulo. Fazendo uns trabalhos com Ana Paula, arrumei um trocadinho comprei um terreno, fiz uma casa. Ela sem saber eu fiz uma casa.

\section{$\mathrm{P} / 1$ : Em Aliança?}

R: Na praia. Fiz na praia de Catuama. E ela morando em Caporama, uma cidade lá da Paraíba. E eu aqui em Pernambuco. Fiz uma casa. Quando foi um dia eu convidei ela para ir lá em casa. Ela veio, quando chegou disse: “De quem é essa casinha?" Eu 
digo: "Eu aluguei." Disse: "Mas renda de casa aqui é caro. Por que você não ficou lá? Eu não dei a casa para você?" Eu digo: "Não, a renda aqui não é muito cara, dá para eu ir me virando." Ela disse: "Que bom, é até aprumadinha a casa." mas eu fiz com meia água, porque o dinheiro estava pequeno. Ela foi-se embora. Dei outra volta em São Paulo, quando eu cheguei ajeitei novamente a casa, ela veio olhou, disse: "Está modificando?" Eu digo: "Estou." Ela foi embora. Eu dei outra volta em São Paulo, aí peguei o produtor, gravei o CD. Ele me deu três mil reais. Depois me deu mais 1500, foi 4500. Eu digo: "Agora, agora." Peguei, descobri a casa, subi as paredes, fiz o chalé. Preparei a casa. Fiz umas apresentação em Brasília, São Paulo, Caruaru, Rio, passei oito dias no Rio com o maracatu. Caiu um trocadinho bom para mim. O quintal da minha casa é grande. Eu peguei fiz uma. Ela lá em Caporama. Eu peguei fiz uma casa. Eu fui buscar ela. Ela, porque estava distante de mim, não sei o que, tá, tá, tá. Eu digo: "Oi, já? Está distante, está sentindo saudade." Eu falei: "Quando eu sentir saudade da senhora eu vou lá." preparei uma casa atrás da minha e chamei ela. Eu disse: "A senhora está reclamando porque está longe de mim. Quer alugar essa aqui?" Ela disse: "De quem é?" Eu digo: "Minha." Ela disse: "É sua essa casa?" Eu digo: "É." "Mas, meu filho, que bom." Eu disse: "É?" Ela disse: "É." "Meu filho arrumou dinheiro aonde?" Eu digo: "No maracatu. Com o maracatu lá para São Paulo, pelo Rio, me deu dinheiro que eu fui." Ela disse: "Eu arrendo, quanto por mês?" Eu digo: "Como é para a senhora, filho com mãe, a senhora vai me pagar 200 reais por mês." Beira-mar, era 80 metros da minha casa para a praia. Quase essa distância aqui. "A senhora vai me pagar 200 reais por mês." Ela disse: "Eu pago 150." Eu digo: "Que bom, vou ganhar o seu dinheiro." Chamei minha irmã, minha filha - que eu tenho uma filha em casa - chamei tudinho. Fui buscar a mudança dela. Ela não estava em casa, eu cheguei lá peguei a mudança dela, trouxe, botei em casa. Quando ela chegou a casa fechada. Ela abriu assim, nada dentro. "Meu Deus do céu, roubaram meus troços tudinho. Roubaram tudo." Botou a mão na cabeça e começou a gritar. Disseram: "Foi seu filho." Disse: "Foi?" "Foi." Ela veio atrás, quando chegou eu disse: "Sua casa é essa." Ela disse: "E a outra de lá, de Caporama?" Eu digo: "Não quero saber." Ela disse: "Vá vender." Eu digo: "Eu não, eu não botei um tostão nela. Agora essas aqui eu botei. Essas aqui pertence a mim, pertence a esse suor. Cantando besteira pelo mundo, deu isso." Quando ela se situou, eu disse: "Agora." Disse: "Lembra quando a senhora batia duas enxada e entregava uma para mim para ir puxar na roça que eu dizia que não queria, a senhora dizia que eu nunca ia ter futuro com o maracatu?" Ela disse: "Lembro." Eu digo: "Ó aí, o maracatu o que me deu. Deu para mim, deu para a senhora." Ela disse: "Mas aqui não é minha." Eu digo: "É sua. A senhora só não leva ela quando morrer, que vai deixar para outra pessoa." Eu tenho uma irmã que vive com ela em casa, eu saio de casa, deixando minha irmã e uma filha que eu tenho, eu estou despreocupado. De onde eu estou eu ligo. Já hoje ligaram para aqui. Eu estou despreocupado. Porque se for doença elas agem, graças a Deus, meu bom Deus, eu não devo a ninguém. Minha família não deve. Eu não pego um tostão emprestado de ninguém para fazer uma viagem. Porque eu não preciso. Sou aposentado, é um sala- 
rinho desse tamanho, mas eu sei dividir ele. Eu sei dividir. Eu não tenho família, não tenho mulher. Minha mulher morreu em 97, apareceu mais de mil para morar mais eu, para casar. Eu não quero não. Eu não vivo em casa. Quatro filho eu tenho. Cada qual tem uma casa muito boa, graças a Deus. Levo qualquer um de vocês e mostro aqui a casa de meu filho. Não faz vergonha entrar na casa dos meus filhos. Essa que está mais eu não tem nada, porque ficou no meu mocotó. A mãe dela morreu ela ficou no meu mocotó. Eu arranjei outra mulher, morou 27 anos mais eu. Morreu. Ela ficou, sou viúvo duas vezes. Eu não arranjei mais outra porque eu estou com medo. Porque possa ser que agora quem vá seja eu. Digo: "Quero mais não, deixa eu sozinho agora." Então essa filha ficou mais eu. Depois que eu aprontei a casa, restaurei a casa todinha a semana passada faltava murar. Comprei o material, mandei murar, está muradinha, bonitinha, de terraço. Água encanada dentro de casa, graças a Deus. Chamei a minha filha de: "Você quer ficar nessa casa pagando aluguel? Porque eu vou morar noutra. Eu não vou ficar aqui na praia não, não gosto da praia." Ela disse: "Mas meu pai, e o senhor tem dinheiro para pagar a renda." Digo: "Uma surpresa para você. Começa a fechar essa casa lá da cozinha." Ela começou fechando. Quando ela chegou onde eu estava deixou a porta de frente aberta. Eu disse: "Feche." Ela fechou, me deu a chave. Quando ela me deu a chave, ficou olhando para mim. Eu disse: "Você só teve vez nessa casa até agora, porque de hoje para diante essa casa é minha. Você é de maior, já tem uma meninazinha, é mãe solteira. Agora se vira." Ela disse: "Mas meu pai, eu vou para onde?” "Não sei." Ela disse: "Eu vou - ela chama avó, não chama vovó, chama vovô - eu vou pedir a vovô para passar uns dias na casa dela, uns dias na casa de João, outros na casa de Manoel, outro na casa de Cema lá na Paraíba, até eu arrumar um quartinho para mim." Eu digo: "Que bom, tá vendo quem luta o que é que faz? Se você botar isso na cabeça você vai fazer o quartinho rapidinho. Mas abre essa porta aqui." Ela abriu. Quando ela abriu eu digo: "Vai lá no meu guardaroupa traga aquela bolsa capanga. Ela trouxe. Quando ela me entregou, tirei o papel da casa, digo: "Toma a chave, toma o papel, a casa é sua. Não preciso disso não." Ela disse: "A casa é de quem, meu pai?" Eu digo: "A casa é sua." "Mas por que o senhor fez isso?" Eu digo: "Porque você tem quatro irmão. Cada qual tem uma casa muito boa. $\mathrm{E}$ você ficou no meu mocotó então não tem nada. $\mathrm{E}$ nem tem posse de fazer. Eu não preciso, é sua. Tome." Ela disparou no choro contar minha mãe. Aí a minha mãe: "O que é Maria, o que é?" Que a minha mãe entrou para 91 anos, em Santana ela fez 90 anos. "O que é Maria?" Já agarrou-se as duas chorando. Ela com o papel na mão: "Vovô, pai me deu a casa para mim." A véia: "Foi José?" Eu digo: "Foi." "Por que você deu a casa a ela?" Eu digo: "Porque ela tem quatro irmão, três, cada qual tem uma casa. E ela ficou no meu mocotó não tem nada. De uma hora para outra eu morro. Ela vai ficar com a casa, mas eu não dei. Vai ficar com a casa mas não dei. Agora ela pode dizer: 'agora eu tenho uma casa que meu pai me deu'. Está satisfeita?" Ela disse: "Estou." Eu digo: "Você está satisfeita, eu não estou ainda. Porque ainda falta eu fazer um serviço nela." Eles sem saberem o que era, e coisa. E quando foi, eu me lembrei que eu tinha trabalhado fichado um tempo. Que é do meu PIS. Vou pro- 
curar. Quando cheguei lá tinha 1800. Eu digo: “Oche.” 1853, eu digo: "Agora me dê ele para cá." Eu fui no armazém, comprei o material, murei ela. Eu digo: "Agora está prontinha a sua casa." Ainda ontem ela ligou, disse: "Pai, o pedreiro terminou a calçada, porque onde cavou a base para levantar o muro. Ele terminou, está tudo pronto aqui." Eu digo: "Está feliz?” Ela disse: "Estou, e o senhor como é que está?” Eu digo: "Eu estou bem, graças a Deus. Estou bem aqui no céu. Só isso a minha vida.

P/1: Mas, pensando um pouquinho na sua infância, como que o senhor via no seu dia-a-dia o maracatu? Ele era quantas vezes por semana? Como é que era? O senhor achava ele na rua?

R: Não, o maracatu era de oito em oito dias. A gente só sambava de oito em oito dias. Às vezes de 15 em 15, porque cansa também. Mas que o sonho meu era de brincar, era de brincar. Chamasse qualquer dia da semana eu ia. Mas, que nesse tempo, o maracatu só brincava de oito em oito dia, de 15 em 15, porque a cultura não tinha conhecimento com o maracatu. $\mathrm{O}$ maracatu era esquecido. Maracatu ninguém dava nada para o maracatu. Mas depois que a cultura viu que maracatu tem futuro, aí a cultura caiu de dentro. Depois que a cultura caiu de dentro do maracatu, quem que não quer se levantar? É porque Pernambuco, se o espírito não me engana tinha, se muito tinha, era uns 10 maracatu. Pernambuco todinho. Uns 10 . Hoje em dia tem 104. Pernambuco tem 104 maracatu rural. Fora o baque-virado. O baque-virado em Recife, aqui e acolá, tem 10,12. Quem sabe é esses meninos que bate baque-virado. Mas rural tem 104. Veja o quanto adiantou? E só vejo nego dizendo: "Maracatu não tem futuro, não tem futuro" e quando dá fé o cara está fazendo um. O que diz que não tem futuro está fazendo um. Mas por que ele está fazendo? Para ver se maracatu tem futuro de riqueza. Não tem. Maracatu, o cara só adianta com maracatu. O dono do maracatu não tem resultado. Quem tem resultado é quem brinca. Porque o dono só faz gastar. Pronto, se você tem um maracatu: "Zé Duda, eu queria que você, eu fiz um maracatu eu quero que você vá mestrar meu maracatu." Eu digo: "Só vou com tantos reais." "Não, eu dou tanto." Eu digo: "Não, Fulano está me dando tanto eu vou para fulano. Você quer que eu vá? Eu vou. Já é um meio mundo de dinheiro que você vai me pagar." Eu digo: "Eu vou por três mil reais. Eu brinco os três dias por três mil reais. Você tem interesse que eu brinque? Eu vou." Aí já é um prejuízo. Aí lá vem a despesa de carro, despesa de fantasia, despesa de comida para aquele povo. Quando é um maracatu de 60 pessoas até 80 é bom. Mas de 160 ? 160 pessoas dentro do maracatu para dar de comer três vezes o dia. Quatro transporte para pagar. Quando finda o carnaval aquele povo cada, o que menos ganha, 40 reais. $\mathrm{O}$ que menos ganha. Porque tem umas crianças que faz parte de aula das baiana. Esse ano ganharam 40 acharam ruim. As criancinha desse tamanho, quatro. Quatro que é para destacar. As baiana adulta para criança. Provando a cultura que a pequena representando a velha, e a velha representando a pequena. Mas esse ano ganharam 40. Uma, por sinal eu tenho uma neta, ela está com nove anos, está desse tamanho. Já brincou esse ano. Ela disse: 
"Vovô, não dá para aumentar esse dinheiro para o ano, não?" Tá vendo? Brincou por 40. Aí ela perguntou a mim: "Ô vovô, não dá para aumentar esse dinheiro não? Para o ano não dá para aumentar não?" Digo: "Realmente, minha filha, dá. Porque esse ano você está começando já 40, quem sabe que no próximo ano você não ganha 80 . Quem diz é o tempo." Ela disse: “É, né?” “Quer dizer que eu já vou ganhar 80?" Eu digo: "Não estou dizendo que você vai ganhar 80, quem vai dizer é o tempo." Então se um cara tiver um jogo de vida com brincadeira ele vai, se ele não tiver ele fica. Ele fica. É de onde ele está para trás. Esse que eu estou, se a agremiação tiver o puder de ser campeão, ser vice, ainda tem uma salvação. E se ele ficar somente como aspirante ele está ferrado. Eu tive sorte com esse maracatu que eu brinco. Eu participei, fui de aspirante participei. Ganhei. Fiquei na chave B, chave B é segunda categoria. No outro ano eu melhorei, já peguei o rolo da passarela o que era, parti com ele, fiz o segundo lugar chave A. No outro ano eu fui já melhorei o brinquedo. No outro ano eu fui. Ganhei o primeiro lugar, fiquei na chave A. Chave A, primeira categoria. Hoje em dia, agora não estou ligando. Eu posso ganhar na passarela para campeão, posso perder, não tem problema. $\mathrm{O}$ dinheiro que o campeão ganhar o meu maracatu ganha. Quero saber que eu estou na chave A e não saio de categoria.

$\mathrm{P} / 1$ : É parecido com a escola de samba?

R: É parecido com escola de samba, o julgamento.

$\mathrm{P} / 1$ : E como que é? O seu grupo é lá de Aliança?

R: É de Aliança.

$\mathrm{P} / 1$ : Quantas pessoas são?

R: São 160 pessoas.

$\mathrm{P} / 1$ : $\mathrm{E}$ a divisão é mais ou menos como?

$\mathrm{R}$ : A divisão é, tem a ala de baiana, 38, 42 baiana. Caboclaria 52, 54, depende da caboclaria. Agora vem rei, vem rainha, vem valete, vem cinco para o terno. Vem três músico de sopro. É uma desgraceira, uma doideira.

P/2: Seu Zé Duda, e quais são os instrumentos do maracatu rural, que é diferente do baque virado?

R: Demais até. Mineiro, porca, que antigamente não era mineiro, era ganzá. Antigamente não era porca, era buzina. Mas é mineiro, porca, gongué. Não era gongué, era gonguê. Mas que é um gongué. Bombo, era surdo. Não é surdo, surdo é para escola 
de samba. É, mineiro, porca, gongué, tarol. Não era tarol, caixa. Caixa, bombo, porca, mineiro, tarol e bombo. Cinco instrumentos, som diferente, as lapadas. Eu poderia até bater esse baque virado, mas não é bem fácil. Agora, do rural eu sei montar e sei tocar tudinho. Lá nos colégios que a gente está dando aula com as crianças eu levo o terno do maracatu. Quando chego lá começo cantar, eles começam dançar. Depois eu paro e vou ensinar eles tocar tudinho. É uma diferença, de um baque solto para o baque virado. Grande diferença, são cinco. É lindo o baque solto.

$\mathrm{P} / 1$ : Explica para a gente então um pouquinho do maracatu rural.

R: É porque eu tenho encontrado, já encontrei maracatu baque virado com 18 bombo, com 30 instrumento tocando. Pelo amor de Deus, onde com cinco eu faço tudinho. E eles com uma zuada que chega dói no ouvido. Quando eu chego na passarela que tem um baque virado na minha frente ou está atrás de mim eu estou agoniado. Eu estou agoniado porque dói no ouvido. Aquela tuia de instrumento. Agora, se cantasse uns negócio aí, mas também tinha razão. É um tipo misturado, é um axé, não sei o que, que eu não entendo bem isso. Aí dificulta que só a cebola. Eu me agoneio demais com aquela zuada. E o baque solto, não, o baque solto é cinco tacadinha amarrada e bons sopro. Músicos tudo bom. Tem músico ruim também, mas tem músico bom. E não só eu, a parte é, a maior parte do povo acha bonito e eu vou ultrapassando.

$\mathrm{P} / 1$ : e o senhor falou que quando o senhor era menino você escutou o mestre cantando, e aí você decorou todas as músicas, lembra?

R: Decorei mas não lembro de nenhuma.

P/1: Ô.

R: Não lembro de nenhuma. Para melhor ainda lembro, quer ver, ou ver lá por baixo se ainda lembro de alguma dele que eu decorei. Finado Antonio Barage. Ele cantava assim: "Na mata nasceu um pau, que nasceu e se criou. O carpinar foi e achou, foi o pé do jatobá. Então ele foi serrar e fez quatro barcacinha, para o filho do governador. Uma banda que me sobrou eu fiz quatro bengalinha. Uma mandei para Aprígio, outra mandei para Doquinha, um eu dei a Zé Birrinha, a derradeira foi minha. O nome dessa bengala se chama Maria Bela da Frida, ou de pontada quem leva lapada dela." Um cara pequeno decorar uma coisa dessa, e muito, e muito. "Um dia eu saí de casa, na sexta-feira bem cedinho, cheguei no meio do caminho ia passando um velhinho com uma cestinha no braço. Eu fui perguntei: meu velho, que é que leva na cestinha? O velho me respondeu: na cesta vai um courinho. Eu perguntei: ô, meu velho, quanto custou este couro. $\mathrm{O}$ velho me respondeu: custou 22 mil réis. Eu disse: meu véio quer dez? E o véio me entregou o coro. Então eu peguei o couro botei na casa do vaqueiro, mandei curtir bem curtido. Tirei da casa do vaqueiro para casa do sapateiro, 
para fazer uma macaca para tu e teus parceiro." Aí, nisso, veja juízo bom o que é, no meio desse povo todinho uma cumprideza dessa, o cara decorar uma desgraceira que o cara cantou tudinho. Hoje em dia ninguém pode fazer mais isso. Nem pode cantar essa cumprideza, porque hoje em dia é rima, é rima, e medido: dez. Se cantar mais de dez está perdido. Se sair fora da rima está errado. Porque o cara disse a mim: "Zé Duda, de tudo que você vê faz um samba?" Eu digo: "Não, eu não sou computador. Mas talvez com um arranjo eu faço." Ele disse: "Esse pedaço de papel, é um retrato, não é?" Eu disse: "É." Aí ele disse, ela disse - até uma moça - disse: "Olha, dá-se o nome de zidro, zidro." Eu disse: "É?” Ela disse: "É. E você faz um samba?” Eu digo: "Faço." "Desse papel?" Eu digo: "Sim. Ele não vai ficar para o presente, vai?" Ela falou: "Não." eu digo: "Então eu faço o samba." Aí ela disse: "Eu quero ver você fazer." Eu digo: "Vou fazer agora mesmo.” Eu disse: “ Olha. Uma moça disse a mim que está cansada de ver retrato que é sem prazer de Figueiredo e Delfim, de Maluf, e daí do Ministro Leitão. Mas um de senhor São João, ninguém prega em meu batente, vou sim rasgar brevemente, um zidro de papelão." Ela disse: "Meu pai do céu, como é que o cara faz uma coisa desse jeito?" "Você não pediu para mim fazer? Você pediu." Ela disse: "Que digue o próximo?" "O próximo? Rapaz, nunca estudei catecismo, para melhor nunca estudei para conhecer catecismo, do próximo?" Ela disse: "Sim." Eu disse: "Como assim?" "Se o pecador é irmão no sofrimento e na prece, dá a ele o que merece, lhe tirarem da prisão. Se tiver televisão em qualquer localidade dá-lhe uma oportunidade, toma parte do programa. Feliz daquele quem ama seu próximo sem falsidade." Aí ela disse: "Meu Deus do céu, como é que se faz?" Eu digo: "Faça uma coisa mais certa." Ela disse: "Eu vinha de Caicó - Caicó? Foi. - passei em uma cidade vi uma procissão." Eu digo: "De quem?” Ela disse: "Se o espírito não me engana era de Frei Damião." Eu digo: "Dá um samba. Um dia que eu ver Frei Damião eu faço um samba." Ela disse: "Faz mesmo?" Eu digo: "Faço. No dia que eu ver eu faço." Eu morando lá nesse Chão de Camará, onde eu tenho o maracatu, fui brincar uma ciranda em Condado. Quando eu chego em Condado estava uma santa missão do padre Frei Damião, do frade. O cara: "Pára aí." Eu com o carro cheio de gente para ir para brincar a ciranda. "Pára aí." Eu parei. "O que é que está acontecendo, o que é isso?” Aí disse: "É uma passeata do Frei Damião." "Eita, meu Jesus, e agora? Agora?" O cara encostou o carro assim e eu assisti. Daí a pouco ele passou bem pertinho de mim assim, uma cruzinha assim, envergado e o povo cantando: "Frei Damião, Frei Damião.” E eu estava com os parente meu, filho meu, no carro da ciranda. Eu disse: "Não sai ninguém, tudo aqui." Aí ficou. Passou a procissão, depois que a procissão passou eu fiquei mesmo de frente à igreja com o carro, porque estava preso no povo. Não tinha por onde passar, nem para a frente, nem para trás. Só depois que terminasse. Eu tive que ficar com aquele povo ali até terminar para poder eu sair. Foi bom. Porque eu conheci Frei Damião. Quando terminou tudo aí eu passei e fui embora. Brinquei a ciranda mas não esqueci da passagem de Frei Damião. Quando é no outro sábado, era sábado de Zé Pereira, no domingo Carnaval. Aí para Aliança. Quando eu chego em Aliança no palco, aí eu lembrei de Frei Damião. Eu disse, comecei can- 
tar umas marchas e coisa, entrei no palco. Quando subi no palco eu fiz um samba, como foi meu Deus? Realmente eu estava com uma lotação. Eu disse: "Eu vinha com uma lotação de uma terra vizinha, passei na cidade tinha, uma santíssima missão. E o frade Frei Damião avistei em minha frente. Eu pedi para meu parente, demora aí um pouquinho, que a missa aponta o caminho para a salvação da gente.” Aí o cara disse: "Rapaz, como é que o cara faz uma coisa dessas." Eu disse, eu vi ele dizendo: Católico." eu estava de frente à igreja ele disse: "Católico, respeite a igreja, não sei o que. Seja fiéis. Não sei o que." Aí deu outro samba quando ele disse. "Sou católico de mister para isso eu sou sem preguiça, todo domingo para a missa eu chamo a minha mulher. E quando ela não quer eu fico tanto valente. Fique aí no batente que eu vou para a missa sozinho, que a missa aponta o caminho para a salvação da gente." Os caras: "Rapaz, como é que tu faz uma coisa dessas?" eu digo: "Procurando a origem." procurando, o cara tem que se pegar em alguma coisa, senão a gente não faz nada. Ou para ser um poeta não faz. Então eu me agarro em qualquer coisa eu me agarro. Vou passando em um canto assim, tanto que eu brincava ciranda, para fazer a ciranda de uma pessoa, de uma beira de praia eu fazia na hora. Em uma praça, sentado em uma praça via um pessoal passando para eu fazer, fazia na hora. O cara disse: "Que pena tu não saber ler." Eu digo: "Você é formado, não chega aonde eu cheguei, analfabeto." "Estava aonde?" Eu digo: "Estava em tal canto. E tu com diploma debaixo do braço: 'sou formado, fiz formatura, fiz isso, fiz aquilo.' e não sai, com uma colher de pedreiro ou então trabalhando de gari. E eu não trabalho para isso, eu trabalho para a cultura." Aí o jogo da minha vida.

P/1: Ô, seu Zé Duda, lá de Buenos Aires, quando foi que o senhor mudou para Aliança?

R: Eu saí de Buenos Aires eu estava com 17 anos, peguei para Recife. Fui para Recife, trabalhei três anos e seis meses. Voltei fui morar no engenho. Cheguei lá botaram eu para a paia da cana. Eu trabalhei três dias: "Não dá para mim, vou voltar para Recife." Quando voltei o patrão não me deu mais o serviço porque eu tinha entregado: "Isso é parada mesmo, foi que eu fiz? Entreguei o serviço, agora volto para pedir ele não dá mais.” eu voltei para o engenho. Chega lá no engenho, felizmente, o senhor de engenho botou eu para carregar recado, levar carta em um canto, levar em outro. Era montado de cavalo. Comecei trabalhar. Depois ele comprou um trator mandou me ensinar, eu aprendi trator. Fui trabalhar no trator. Depois ele vendeu o trator, caminhão, eu passei para o caminhão. Fui carregar cana em caminhão. Trabalhei três anos, deixei o caminhão dele, fui para a Usina São José, fui carregar cana no caminhão. Saí da Usina São José, fui para a Usina Santa Teresa. Goiana. Cheguei lá trabalhei dois anos no caminhão, deixei, fui embora para a Usina Aliança, fui carregar cana no caminhão do dono do maracatu. E comecei nesse jogo, nesse jogo. Depois eu deixei: "Não quero mais dirigir. Não quero mais dirigir não." "Mas por quê?" "Eu quero aprender fazer cangalha para burro.” Que lá era um armazém de cangalha. Eu disse: 
“Trabalhando em caminhão é batida aqui, é batida acolá. É virada, é gente morto. E se eu aprendesse a fazer cangalha era bom porque só é dentro do quarto aqui, não tem problema. Só se for uma furada com agulha. Eu queria aprender." O dono do maracatu disse: "Mas, Zé Duda, tu deixar de estar no caminhão para aprender fazer isso?" "Eu quero aprender." E é que eu aprendi. Trabalhei 18 anos fazendo cangalha. Foi tempo que ele morreu eu saí de lá. Saí de lá ele, mas fiquei fazendo cangalha em uma cidade por nome de Vicência. De Vicência eu vim embora para a praia. Cheguei na praia o cara que eu fui morar perto da casa dele tinha um armazém de cangalha. Eu fui fazer cangalha. Quando foi depois eu deixei, fui trabalhar mais um pedreiro. Eu trabalhando dentro de casa sem levar sol, sem levar chuva, fui trabalhar mais um pedreiro. A mão cheia de calo, estourando, tinha dia que amanhecia chega fedia a minha mão. Mao fina que nem ladrão de galinha, quando amanhecia o dia, mão cheia de calo. Eu digo: "Mas trocar a profissão por essa?" Aprendi um bocado de coisa como pedreiro, trabalhei nove anos como pedreiro. Aprendi um bocado de coisa com ele. Chegou minha aposentadoria eu digo: “Agora é mundo.” Aí só mundo.

\section{$\mathrm{P} / 1$ : Mas sempre tocando, né?}

R: Sempre tocando, sempre tocando. Quando eu não vou com o maracatu vou com o cavalo-marinho. De tudo eu vou. O cavalo-marinho de Mestre Grimaro. Quando eu não estou com o maracatu eu estou com o cavalo-marinho de mestre Grimaro. Quando eu não estou com o de mestre Grimaro eu estou com o de lá de Chão de Camará, do maracatu. Que lá tem maracatu, na sede de Estrela tem maracatu, tem cavalo-marinho, tem coco e tem ciranda. São quatro agremiação lá no Ponto de Cultura.

$\mathrm{P} / 2$ : Mestre, conte a história do encontro do senhor com a criança de 10 anos, como foi?

R: Que bom, e vou contar agora. Vou contar para encerrar. Eu venho fazendo, cantando maracatu, rodando o mundo, eu já conheço uma parte do mundo, graças a Deus. E até aqui eu não encontrei uma pessoa para fazer eu tremer, nem sequer ficar emocionado. Mas deixe que eu encontrei. O menino é do tamanho dessa menina, me fez chorar. Está fazendo dois meses, que ele me fez chorar, o menino. Em Patininga com uma vilazinha que é município de Aliança, ele me fez chorar. Porque eu comecei nos colégios, dando aula de maracatu para os meninos, Bil dava aula de coco, eu dava aula de cavalo-marinho também. Mas que tem o mestre de cavalo-marinho. Mais que eu canto é no cavalo-marinho, que eu faço três partes. Canto maracatu no projeto, canto cavalo-marinho e, para chatear, ainda canto ciranda. O Bil só canta coco. Mas dá uma ajuda em mim no cavalo-marinho. Eu chego no Patininga, meio mundo de menino dentro do colégio. Eu disse: "Iniciar o cavalo-marinho." Iniciou o cavalo-marinho, a gente tem o 40 minuto de cavalo-marinho. Quando chegou no maracatu, minha amiga, chegou um cara disse: "Zé Duda, tu não sabe de nada.” Falei: "O que?" Disse: "Aqui tem um menino que canta maracatu." Eu disse: "Não acredito. Porque 
tanto cabra velho na profissão, quando emparelha um homem comigo para trocar idéia fica nervoso, tremendo, com medo de mim. E aqui tem um menino?" Disse: "Tem." "Só acredito vendo." Quando eu me virei assim, disse: “Aqui menino." Eu fiquei em pé, ele ficou aqui assim em mim. Eu olhei assim para ele eu disse, com a mão na cabeça dele, disse: "Você canta maracatu?" Ele disse: "Canto." "Tem certeza?” Ele disse: “Canto. E eu só não vou cantar agora porque eu estou com a farda da escola. Você deixa eu ir trocar de roupa?" Eu digo: "Vá." Para mim, ele morava longe. Ele morava bem pertinho assim. Vapt, vupt, que nem Chico Anísio. Vapt, vupt. Quando eu estava conversando com outros alunos assim, ele puxou aqui na minha camisa: "Já cheguei, estou pronto." Aí fechou de gente em cima dele. Ele disse: "Eu só não vou cantar porque não tem apito." Eu digo: "Eu tenho." Eu estava com dois apito, eu digo: "Tome um." Ele pegou o apito, aí eu puxei de frente. Quando eu puxei de frente ele acompanhou. Quando ele acompanhou eu olhei para o menino assim, e o povo fechou em cima. Fechou em cima de mim e dele, né? E ele não abriu parada não. Disseram assim: "Zé Duda, canta um sambinha de má criação, dando lapada." Fiz um jogo com ele. Porque o maracatu que eu brinco é Estrela. Eu fiz um sambinha assim, eu disse: "Quando eu deixar de brincar para essa estrela amarela, o coral que vim pra ela vai tremer de perna bamba sentindo o peso do samba, que eu canto na frente dela." Ele olhou para mim, mas menino, me passou um carão triste. Ele disse: "Zé Duda, não é assim que se faz, porque você não começou assim não. Você começou escutando os outros e levando uma cipoadinha. Não pode dar nos outro assim não." Eu meti as duas mãos na cabeça assim, que disciplina desse menino. Eu disse: “Tem razão. Mas eu vou fazer outro." Eu disse a ele: "Quando eu deixar de cantar, para um pessoal que me ama, para apagar minha fama fica emocionado vendo um mal assombrado correndo em cima da cama." Aí ele disse: "Nesse aí eu não entro não, mas em outro eu entro." Eu sei que eu bati um papo com ele e ele cantou lá um samba. É porque eu não decorei o dele, né? Quando terminou, aí ele ficou alisando meu braço. Ficou alisando meu braço dizendo: "Zé Duda, eu gostei muito de você." Aquilo me trancou. Agarrado comigo mesma coisa que fosse um filho meu. Aquilo me trancou, me trancou de eu não poder falar. Aí as lágrimas veio. Disse: "Quem é seu pai?” Ele disse: “Meu pai mataram.” Quando ele disse: "Meu pai mataram”, aí outra tacada em cima de mim. Eu digo: "Quem é sua mãe?" Ele disse: "Minha mãe é uma bêbada, só vive bêbada pelo mundo." Eu digo: "Outra cipoada. Mas quem toma conta de você?" "Meu avô e minha avó." "E quem é seu avô?” Ele disse: "Esse aqui." $\mathrm{O}$ avô dele brincou seis anos de caboclo mais eu. Não está brincando agora porque não pode. E eu não sabia. Eu digo: "Meu avô é esse aqui." Eu digo: "Meu pai do céu. E sua avó?” Disse: "Está em casa.” Eu digo: "Seu Antonio, eu preciso desse menino. Eu quero ensinar esse menino cantar maracatu, Antonio.” Aí estava a câmara, tinha duas câmara. Estava o fotógrafo lá do Ponto de Cultura. Eu disse: "Filma direitinho esse menino, tira as foto direitinho, que eu vou aproveitar esse menino." "Vai, Zé Duda?" Eu digo: "Vou." "É difícil. Duvido tu tirar esse menino." Disse: "Tem nada não, mas eu vou lutar pelo menino. Eu gostei do menino." Quando terminou eu fui 
na casa da avó. Quando cheguei lá ela me recebeu muito mal. Disse: "Bom dia." Ela disse: "Bom dia, o que é que você quer?" Eu digo: "Nada. Queria conversar com a senhora." Disse: "Eu não tenho nada que conversar com você. Para melhor, não lhe conheço." Eu digo: "Mas vai conhecer. Que idade a senhora tem? Desculpe eu perguntar sua idade." Ela disse: "Eu tenho 72 anos." Eu digo: "Já dá para isso mesmo." Ela disse: "Dá para isso o que?" Eu digo: "Quase caducando.” Disse: "Mas finalmente, o que é que o senhor quer?" O marido dela foi chegando. Eu disse: "A senhora é a mãe daquele garoto que canta maracatu?" Ela disse: "Sou, por quê?" Eu disse: "A senhora não deixa aquele menino brincar maracatu com outra pessoa não?" Ela disse: "Não tem quem tire ele daqui." Disse: "Tá bem." Também eu não pedi ele, não pedi nada. Deixei lá e fui embora. E caminhei para o Ponto de Cultura. Quando foi no outro dia as fotos chegou. O cara veio me trazer as fotos, por sinal muito bem tirada as foto. Eu tenho um CD gravado por mim, eu fui no escritório lá no Ponto de Cultura, peguei o CD, peguei as fotos dele e disse: "Eu vou se essa mulher tem força de brigar comigo agora." Que ela estava agitada com meio mundo de gente na frente da casa dela e agora eu vou sozinho. Chamei o cara de uma moto assim, que mora ali no Patininga mais eu. Quando cheguei lá na, a casa dela pega duas rua, eu cheguei na primeira, fechada. Eu arrodeei, aberta. $\mathrm{O}$ marido dela estava lá fora. Quando me viu ele veio. Eu disse: "Antonio, cadê tua mulher?" Disse: "Está lá dentro." "Chama ela aí." Ele chamou ela. Quando ela saiu, o vestidão todo sujo. Era aquele povo antigo. Eu disse: "Bom dia, patroa, tudo bem? Já esfriou a cabeça?" Disse: "Quem é você??" Eu disse: "Aquele mesmo que conversou com a senhora anteontem." Disse: "O que é que você quer aqui?" Eu digo: "Eu vim saber se a senhora conhece esse aqui?" A foto do filho dela. "A senhora conhece esse aqui?" Ela disse: "Nunca vi." Eu disse: "Como é a história?" Ela disse: "Nunca vi." Eu peguei outra foto, eu digo: "Conhece esse aqui?" Ela disse, chegou até a botar a foto de cabeça para baixo. Botou aprumada, depois arrevirou. Disse: "Meu filho." Eu disse: "É seu filho?” Disse: "É.” Eu digo: "Pois é ele que eu quero." "Meu filho?" Eu disse: "Sim." Ele não estava em casa, ele estava jogando bola de gude na rua. Não sabia que eu estava na casa dele. Ela disse: “Ah, isso não.” Daí a pouco ele chegou. Disseram a ele lá pela rua: “Zé Duda está na tua casa." Ele veio de carreira, sem camisa. Quando ele chegou, bateu no meu ombro: "Tudo bom, meu mestre?" Agarrou-se comigo, já foi chorando. "Tudo bom, meu mestre?” Eu digo: "Tudo bom.” Peguei ele, botei no braço. Ele é tão pequeno que eu botei ele no braço. Ele disse: "Meu mestre, bota eu no chão." Quando eu botei ele disse: "Desculpa aí, viu?” Eu disse: Tá bem." Aí ele, chegou lá, vestiu a camisa, abotoou a camisa até aqui. E quando chegou disse: "Agora eu posso falar com você, modo eu estava despido." Outra tacada em cima de mim, o menino. Eu pego a foto dele, eu digo: "Você conhece esses?" "Ele disse: "Meu pai do céu, minha foto, Mestre Zé Duda, minha foto." Eu digo: "É tua.” Ele disse: “Ô, meu Deus, cada um melhor que o outro." Ele tem 10 anos lê tudo, lê mesmo. Eu disse assim: "Suas fotos, o CD de presente. Você não é meu fã?" Ele disse: "Sou indo e voltando.” Eu disse: “Agora, quer brincar maracatu comigo?" Ele disse: "É meu sonho é brincar com você.” Agora, 
vamos brigar mais a mãe dele. Aí a casa entupiu de gente. A casa é grande. Entupiu de gente. Quando entupiu de gente ficou brigando eu e ela. Ela disse: "Olha, não tem que tire o meu filho da minha mão." Eu disse: "Isso vai doer na sua testa, isso que a senhora está dizendo vai doer na sua testa. Porque os tios liberam o menino, o avô libera o menino. Se a mãe do menino estivesse aqui ia liberar, só se ela estivesse muito cheia de álcool. Mas se ela estivesse numa boa ela ia liberar. Porque eu vou ser responsável o menino. $\mathrm{O}$ que acontecer com o menino o responsável sou eu, e a senhora não tem essa responsabilidade tão grande por ele. Porque se a senhora tivesse não deixava ele estar jogando bola de gude lá na rua sem camisa. Responsabilidade que a senhora tem? Se a senhora tem esse privilégio pelo menino ele estava aqui no seu quintal que é grande, olha aí. Mas ele estava jogando lá no meio da rua. Sujeito o cara jogar uma pedra na cabeça dele, chamar para um beco daquele dar um cigarro, dar erva a ele." Aí o povo: "bate palma: pá, pá, pá, pá.” Ela já foi se encabulando. "Mas como a senhora está cortando a sina do menino - e ele pegado comigo - a senhora está - ele olhava para eu assim, chorando, não podia dizer nada, né? - mas como a senhora está cortando a sina do menino, eu não vou ficar com raiva da senhora não. Agora, Deus vai dar o pagamento à senhora. Não vai dar a ele não, vai dar á senhora. A senhora vai fazer assim não cai um pingo de suor. $E$ talvez, que esse menino um dia ainda diga: 'tome vó, isso é dinheiro de maracatu.' Quem sabe que ele não faça isso. Mas muito obrigado.” Aí ele disse assim: “Zé Duda, você me deu um presente muito lindo, seu CD. Mas eu vou guardar porque eu não tenho rádio.” Aí casa cheia de gente, chegou João Inácio, um colega meu, disse: "Lá em casa tem dois rádio grande de CD." Chamou uma filha e disse: "Vá buscar um daquele." Foi e disse: "Olha aqui o rádio." Eu digo: "Decore esse CD. Você é bom de decorar?" Ele disse: "Sou." Eu digo: "Decore esse CD e pode cantar em qualquer maracatu que tem nesse CD. E se alguém disser: ‘é de Zé Duda', você diga: ‘foi ele que me deu, transmitiu para mim’. E muito obrigado pelo presente que a senhora me deu, viu dona?" Fiz que ia embora. Mas que eu não ia embora. Eu tinha que abater aquela mulher para ganhar o menino. E ele dizendo: "Zé Duda, não vai agora não, Zé Duda." Eu digo: "Vou embora, porque não tenho mais que conversar com a sua avó.” Quando eu cheguei na calçada o avô dele me chamou: "Zé Duda, vem cá." Eu voltei. "Fala." Ele disse: "Você está vendo que a culpa não é minha." Eu digo: "Não, você liberou. Ela é quem não pode, não libera e coisa. Mas Antonio, o que eu disse a ela eu digo a você. Talvez que esse menino, ou seja, parece que não vou morrer agora porque Deus não quer, talvez que esse menino ainda dê um pó a vocês. Porque eu a mesma coisa de mim. Sabe por que eu estou interessado nesse menino? Porque esse menino botou a cara em maracatu completando 10 anos. Completando 10 anos foi quando eu botei a cara em maracatu também, foi eu completando 10 anos. Foi o meu presente. E hoje em dia tudo que eu tenho eu agradeço a maracatu. Então, quem sabe que esse menino não vai fazer isso com vocês. Mas ela não quer. A senhora não merece isso não." Ela encostou para perto, eu digo: “A senhora não merece isso não. Tchau, viu?” Ele disse assim: "Zé Duda, me visita sempre, viu, Zé Duda?” Aí me trancou de novo. Porque que coisa 
boa, uma pessoa estar querendo o outro, o outro querendo chegar. E o outro cortando. Aí dói. Eu desci para o meio da rua, o cara da moto que eu fui em uma moto de aluguel, o cara: "Eu não estou avexado não, Zé Duda, pode conversar o dia todinho. Eu sei." Eu desci, cheguei perto da moto, o povo cercado. Ficou uma turma de gente dentro de casa e outro cercado no meio da rua. "Zé Duda, o que você está fazendo está lindo demais, está bonito." Ela foi e disse: "Estou admirada com esse povo, que só passa de facão para o lado daqui." Ela me chamou. Eu já ia montando no bagageiro da moto, mas que eu não ia me embora não. Eu ia passar lá umas duas horas ou três, brigando com ela. Estava dando um susto nela. Voltei, disse: "Olhe, dona, eu não tenho mais nada a conversar com a senhora." Ela disse: "Faça o favor, entre na minha casa.” Eu digo: “Agora.” Aí eu entrei. "Diga o que é que a senhora..." "Sente.” Eu digo: "Eu não quero sentar não. Eu já ouvi tudo da senhora, a senhora não tem mais nada a me dizer." Ela disse: "Mas sente, por favor." Eu sentei. Olhei para ela, ela estava pingando lágrima. "O que é que a senhora quer dizer?” Ela disse: "O senhor sabe por que eu não libero o menino?” Eu disse: “Não, só a senhora dizendo. Porque se eu soubesse eu já tinha ido embora." Ela disse: "Porque esse carnaval, aqui tem dois maracatu na rua, ele passou os três dia brincando em um. E não deram nem sequer água para ele beber. É por isso que eu não deixo o menino ir." Eu disse: "É?" Disse: "É." Eu digo: "Ah, pois, se ele fosse brincar mais eu ele não morria de sede nem de fome." "Mas o senhor se responsabiliza por ele?" Eu disse: "Desde que eu tirar ele da sua casa eu tenho, se eu tirar ele em um domingo de carnaval na terça-feira quando eu chegar com o maracatu, eu tenho que vim trazer ele na sua casa. Porque foi eu que tirei, eu tenho que vim trazer. Eu não mando não, eu venho trazer. Mas já que a senhora não quer - cada vez eu dava uma tacadinha nela - já que a senhora não quer eu estou tomando o seu tempo. E tudo bem." Fui saindo. Ela puxou aqui na minha camisa: "Seu Zé Duda venha cá." Eu disse: "De novo? A senhora já está esquentando minha cabeça.” Ela disse: “O menino está liberado, o menino está liberado.” Eu digo: "Está?" “Tá." "Quando é que o senhor precisa dele?” Eu digo: "Quando eu precisar eu venho aqui até a senhora e Antonio, eu digo: vim buscar o menino. Levo ele. Quando eu terminar as apresentação eu volto: olha aqui seu menino. Tá certo assim?” “Tá, Zé Duda."

\section{P/1: O Zé Duda conta pra gente como começou o ponto de cultura em Aliança?}

R: E a gente começou a trabalhar. A casa lá, a sede estava estiorada. Aí produtor caiu de cima. A gente restaurou a casa, preparou a casa. Disse: "Agora vamos lutar pela biblioteca." Coisa linda. Fez escritório, fez estúdio de gravação. Por sinal botaram até o nome que eu digo: "Rapaz, esse nome está errado. Porque tem escritório, estúdio de gravação do 'Mestre Zé Duda.” Aí sabe o que foi que aconteceu? É porque lá grava. Aconteceu, os meus colegas souberam. Tudo pediram a mim para gravar: "Mas Zé Duda, tu não tem um estúdio de gravação?" Eu digo: "Olha quanto foi errado isso. Eu disse a você.” Ele disse: "Deixa o cara vim, rapaz.” Eu digo: “Quanto foi errado. 
Porque meu amigo aí tem um maracatu, quer gravar, fazer um CD aí vem pedir para mim gravar. O estúdio não é meu. Você tinha botado outra coisa." Ele disse: "Mas tem que ficar esse nome." Então tem estúdio de gravação, tem biblioteca, lá tem o quarto do coco. Tem o quarto do cavalo-marinho. Tem uma equipe muito dengosa que a gente trabalha com ela. E a gente faz as festas, ele fez 10 festas. Todas as qualidades de agremiação maracatu desfilando. Tinha noite de apresentar dois maracatu, apresentava coco, ciranda, caboclinho, boi. Sim, a gente tem outra agremiação, tem o boi. Tem o boi. É maracatu, coco, ciranda, cavalo-marinho e o boi. É cinco. Tem o boi. O meu mestre caboclo brinca um boi. E eu sei que a gente armou. A gente armou e agora o ano passado a gente, esse produtor, todo ano ele fazia o Festival do Canavial em Nazaré. Mas o Ponto de Cultura lá da gente ganhou um terreno que tinha na frente, aí abriu o terreno e o Festival do Canavial vai ser. Então a gente está convidando agremiações que queira agora a partir de novembro, se o espírito não me engana é a partir de um, de um de novembro. Não estou bem informado não, mas o professor sabe. São seis dias de festa. Todas as qualidades de agremiação, é uma coisa linda. Tem o pessoal que trabalha, tem no escritório. Tem gente fazendo, trabalhando bordado, gola. Lá tem faxineira, tem tudo, tem tudo. Cada carro tem o seu salariozinho. Equipe que anda comigo são seis, que a gente anda nos colégios. Agora, a gente seis faz tudinho. Porque a gente sabe jogar, sabe bater tudo, sabe tocar tudo. A gente seis faz a festa. E dos Pontos de Cultura que a gente já rodou eles, a gente ainda não ficou abaixo de um não. Só se aparecer um lá na frente que, mas a gente não ficou. Possa ser que a gente deu um empate com algum. Mas a gente não ficou ainda não. Então deu uma animação muito grande o Ponto de Cultura. Mas, mais gente trabalhando, mais gente querendo aprender. Sim, tem outra agremiação lá também, que eu ia esquecendo, tem um Xangô. Tem um Xangô.

\section{$\mathrm{P} / 1$ : São seis então?}

R: É, um Centro de Xangô lá. O meu rei, que brinca o maracatu, é o pai do terreiro. É o Centro Nossa Senhora da Conceição, parece. E é um espetáculo. De todas as gremiação que procurar lá no Ponto de Cultura, encontra. Encontra.

$\mathrm{P} / 1$ : $\mathrm{E}$, desde o começo você foi convidado para ser mestre?

R: É não. Foi feito a partir de, está com três, parece que está fazendo três anos que a gente fez isso. A gente veio somente, tinha a sede, né? O Ponto de Cultura armou há três anos, parece. Agora, que o produtor já trabalhava lutando para fazer. Procurando recurso, procurando ajuda, patrocínio. E até que encontrou.

P/1: E o que o senhor acha da tradição oral? Da importância assim da, dessa tradição, dessa cultura que vocês passam, a organização que vocês têm? 
R: Eu acho tranqüilo, eu acho tranqüilo. Para mim é bom porque chegar em um lugar estar 40, 50 pessoas querendo que você ensine a ele cantar maracatu, ensine cantar ciranda, ensine cantar coco, dançar, fazer isto, fazer aqui, é bonito. Aquilo dá um prazer para quem está ensinando. Agora, o pior é quando a gente vai ensinar uma coisa e que o cara: "Quero aprender isso não. Isso não tem futuro." Porque antigamente maracatu não tinha futuro porque era dança de negro. Mas o negro chegou onde o branco ficou. Tem muito negro lá na frente, que o branco está lutando para chegar atrás, onde está o negro. Então não vamos distinguir. Não vamos distinguir. Porque cada cara tem que puxar da cultura. E com esse Ponto de Cultura é que o cara sabe de coisa. Porque foi não foi chega uns aluno sabido, que é bom. Eu gosto de conversar com os aluno, ele procurando, mexendo com cultura. Eu gosto. Porque eu digo: "Eu não sei não, não entendo bem cultura não. Eu entendo cantar maracatu. Agora, cultura eu não conheço não." Ele: "Mas, Mestre Zé Duda, tem isso, tem aqui." Eu digo: "Onde você encontrou isso? Porque isso não é assim, é desse jeito e desse." Ele diz: "Ô, Mestre Zé Duda, que bom." Mas deixe que ele foi acordado por mim, que ele dormia. Ele veio perguntar uma coisa que ele sabia. Mas eu me neguei, porque para ver que era a reação dele. Então tem muita gente que vive da cultura, luta por ela. E o pior lugar é o que a gente vive. Porque tem uma cidade por nome de Nazaré, já tem o nome: A Terra do Maracatu. Nazaré é a terra do maracatu. Até os carros da prefeitura. Tudo tem o nome de maracatu e as fotos dos caboclo. Os ônibus da prefeitura. É a terra do maracatu. São os aluno mais perigoso que existe. Porque eles conhecem maracatu de um tudo, eles. Então quando eles saem para fazer um trabalho nos Ponto de Cultura, quem estiver lá se prepare que eles só vão pesado. Só vão pesado. A gente não, a gente não se assombra não. Pronto, a gente está recebendo um maracatu de mulher que tem em Nazaré. Só mulher. Não tem um homem no meio. É músico, batuqueiro, mestra, tudo, tudo é mulher. Não tem um homem para dizer assim: "Esse homem está tomando conta do maracatu." Não, é mulher. Tudinho, tudinho. E é lindo. Grande, grande mesmo, e é lindo. Então eles vão para lá, para a semana eles vão para lá gravar o $\mathrm{CD}$. Vão gravar o $\mathrm{CD}$ lá, e a gente está esperando. Vai dois maracatu gravar o CD. O caboclinho já gravou, Bil já gravou. Aí é, quem é o outro? Tem um outro que está querendo ir para gravar. E próximo mês é a Festa do Canavial. Os ticoqueiro, quem estiver bom que se prepare para ir para lá. Porque lá tem tudo, tem tudo o que procurar.

P/1: Zé Duda, eu queria agradecer muito pelo Museu da Pessoa. Espero que a gente se reencontre muito.

R: Quem agradece sou eu. Agora, eu peço uma desculpa, você querer, o analfabeto fala muito errado. Aí quem pede desculpa sou eu. Mas para mim é um prazer. Porque eu não sabia onde era São Paulo. Aí lá vai eu para São Paulo. O cara me levou para São Paulo. Fui lá para Ibirapuera. Não, Sesc Pompéia. O Antonio Carlos Nóbrega, me levou. Quando eu chego lá, uma foto minha: "Vixe, aqui? Espera aí. Quem trouxe 
para aqui?" Ele disse: "Eu. Você não é meu convidado? Eu mandei lhe buscar, tinha que botar sua foto." Aí um bocado de gente lá: "Eu já vi esse camarada." Outro: "Eu já vi ele." Um dizia: "Eu vi em Recife." Outro: "Eu vi em Nazaré." Disse: "Meu Pai do céu. Quando eu pensei que estava sozinho estava cercado." Então aquilo que eu dou de presente é outro presente que eu ganho. Quando eu dou fé, é uma coisa dessa. Quando eu dou fé alguém me para e pergunta: "Mestre Zé Duda, está lembrado de mim? Tal canto assim." o quanto é bom isso. Mas se eu me negar de fazer isso, sei que vocês não dizem, mas tem outra classe que diz assim: "Aquele é imbecil, aquele é imbecil, não sabe nem se apresentar. Não sabe o que perdeu.” Quem sabe o quanto eu ganho com isso? Ir para o museu? Depois de morto vou para a terra, mas o meu nome fica no museu. É para mim uma tranqüilidade. Só resta dizer muito obrigado.

P/1: Só tenho a agradecer pelo Museu, a gente sente muito feliz de estar trabalhando junto com a Ação Griô, e conhecer pessoas maravilhosas como o senhor.

R: Então muito obrigado. E, só é o que me resta dizer.

\section{Depoimento de Maria de Fátima da Silveira Santos Entrevistada por Thiago Majolo e Cláudia Leonor Vassouras, 26 de maio de 2007 Realização Museu da Pessoa Transcrito por Suely Aguilar Branquilho Montenegro}

$\mathrm{P} / 1$ : Pra começar, eu queria que você dissesse primeiro o seu nome completo,o local e a data de nascimento.

R: Meu nome é Maria de Fátima da Silveira Santos, mas eu sou mais conhecida como Fatinha. Eu nasci em Pinheiral em 13 do sete de 56.

$\mathrm{P} / 1$ : Conta um pouco sua origem, seus pais, de onde eles vieram.

R: Bem, meu pai ele nasceu na fazenda da Bem Posta, aqui na região de Petrópolis, Três Rios. Foi trabalhador da Light durante 35 anos e já é falecido. E a minha mãe, ela é de Minas Gerais, da cidade de Santo Antonio do Monte e nós já estamos moramos em Pinheiral há muitos anos. Desde que eles casaram foram pra Pinheiral e a gente reside lá até hoje. Nossa família e a minha mãe. Ela é descendente de índios e africanos, então a gente tem assim uma mistura muito, muito legal.

$\mathrm{P} / 1$ : Como é que era na sua infância? Conta um pouco da sua casa, onde você morava. 
R: Bem, a minha família sempre foi, desde os meus avós, uma família assim muito, muito batalhadora, muito consciente, principalmente na questão da nossa etnia, de sermos negros e tudo. Então, a gente cresceu já num ambiente de conscientização muito forte, sabe, sempre assim valorizando muito tudo que a gente tinha, tudo que a gente trazia, toda a nossa história, isso acontece até hoje. Nós somos militantes de movimento negro, a gente participa de muitas lutas, está presente sempre em tudo que fala da cultura afro, mas isso vem de família mesmo. Meus pais e meus avós, por exemplo, a minha avó Bárbara, que a gente conviveu muito, eles não tiveram uma formação. Estudaram até a quarta série no máximo; a minha mãe que fez atualmente até a oitava série, mas eles sempre tiveram uma vivência muito grande e isso foi passado pra gente. Então, nós temos um jeito de viver bem peculiar, bem legal, bem legal. Isto foi passado pra mim, meus irmãos. Agora a gente passa pros filhos, netos...a minha família é uma família muito legal.

\section{$\mathrm{P} / 1$ : Mas esse aprendizado é da cultura?}

R: É da cultura porque vocês sabem que nós, enquanto negros brasileiros, temos uma dificuldade muito grande em tudo. É questão de estudo...a família negra brasileira, ela é uma família que tem muitas dificuldades, tudo pra gente é difícil, é uma luta todo dia, todo instante. A sociedade, ela fez um trabalho tão perverso com os negros, que tem muito negro que aceita essa condição, o que não aconteceu na minha família. Eu já falei, desde os meus avós, a gente sempre procurou estar inserido dentro da sociedade e todo o espaço que a gente busca ocupar, a gente sempre consegue. No caso, vem da minha geração, da minha família. Todos nós somos formados vendo a cidade. Os meus filhos, sobrinhos, tão vendo pelos mesmos caminhos. A gente procura trabalhar, enquanto negros, lutando pelas oportunidades. Então, isso eu acho muito forte, porque eu lido com outras famílias de negros na nossa comunidade, que a gente assim tem muito trabalho de mostrar a ele que a gente tem direito a tudo. Porque esse processo que a sociedade fez de falar que o negro é inferior, que o negro não pode isso, não pode aquilo, muitas pessoas da nossa comunidade aceitam isso. Então eu vejo essa diferença da minha família pra outras famílias porque a gente nunca aceitou. A gente sempre buscou trabalhar essa situação.

$\mathrm{P} / 1$ : E são quantos irmãos?

R: Nós somos seis, comigo seis.

$\mathrm{P} / 1: \mathrm{O}$ que eles fazem?

R: Eu tenho uma irmã que é bióloga, e ela é diretora de escola, tem a outra que é pedagoga que também trabalha em escola, meu irmão, que é administrador, é professor 
e trabalha na Light e os outros dois que são gêmeos, os caçulas, são advogados, todos dois.

P/1: Conta um pouco assim, a cidade como ela era, o que está mudando.

R: É uma cidade do interior. Na época do império, época áurea do café, aqui no vale teve uma fazenda: São José do Pinheiro. E essa fazenda, ela foi muito próspera e a gente tem ainda descendentes de negros que foram escravos dessa fazenda e a cidade cresceu em torno disso. Aí, fundou a estação e daí da estação expandiu. Então, pertenceu a Piraí, que é uma cidade maior por muito tempo e atualmente ela tem dez anos de emancipada. É a típica cidade do interior, mas a gente tem uma educação de qualidade, várias escolas, da prefeitura, do Estado. É uma cidade pequena, tem em torno de 25 mil habitantes, e na questão da cultura, o jongo que a gente mantém, esse jongo que vem desde a época da fazenda, o jongo de Pinheiral, ele nunca teve interrupção, ele sempre foi passado de geração em geração e atualmente tem uns 30 anos mais ou menos que a gente conseguiu fazer um grupo mais organizado e trabalha isso em nível de Sul do Estado, de Rio de Janeiro, e é um jongo assim que ele é bem considerado, porque a gente procura manter a tradição. Não houve mudanças. Mesmo quando a gente faz palco, a gente faz questão de mostrar a tradição nossa. Então, é um trabalho bem interessante.

$\mathrm{P} / 1: \mathrm{O}$ que você estudou?

\section{R: Eu fiz Educação Física.}

$\mathrm{P} / 1$ : Conta um pouco dessa época pra gente.

$\mathrm{R}$ : Essa época foi muito interessante, porque eu sempre fui muito, muito grande, então, eu praticava esporte, jogava, adoro handball, mas eu fui estudar no colégio agrícola - eu queria fazer veterinária - aí, naquela época, a gente pra entrar pra faculdade federal era muito difícil e lá nesse colégio era interessante - alguns anos atrás não só no colégio, no Brasil tinha uma tal duma lei do boi e quem era filho de fazendeiro tinha $50 \%$ de vantagem pra entrar na faculdade, e a gente que não tinha não entrava. Eu fiz vários vestibulares, vários Estados e tal, mas essa lei dificultava muito. Ou você tirava o primeiro lugar ou você não entrava, então, eu acabei não fazendo veterinária que eu queria fazer. Aí, como eu gostava muito de esportes pela minha estatura, eu fui fazer educação física e fiquei na educação física. Aí, consegui fazer um trabalho que faço até hoje: trabalho em escolas, sou coordenadora de educação física e tal, mas já estou quase aposentada. Acabei indo por esse lado e paralelo a isso, envolvida com a cultura, como movimento negro, Então eu consigo trabalhar nas duas áreas.

$\mathrm{P} / 1$ : Conta um pouco desse movimento que você participou e da sua participação. 
R: A minha entrada pro movimento negro aconteceu da seguinte forma: lá em Pinheiral a maioria dança jongo porque é tradição. E em Volta Redonda tem um clube, ele chama Clube Palmares, que foi fundado por engenheiros negros que trabalhavam na CSN, porque lá em Volta Redonda tinha três clubes que os negros não podiam entrar. Então, esses engenheiros foram os primeiros negros na CSN, e eles fundaram esse clube, Palmares. Existe até hoje esse clube, muito grande na questão da cultura negra, e um dia a gente tava com uma festa lá porque é tradição nossa no 13 de maio a gente fazer uma reflexão sobre a data. Então, a gente faz a reflexão e depois dança. Aí, a gente tava nessa atividade e foram algumas pessoas desse clube visitar o nosso trabalho. Eles ficaram assim apaixonados. Aí, ia ter um outro trabalho lá em Volta Redonda, na vila, que é um lugar nobre, e eles: "a gente vai levar vocês pra dançar lá'. Nós fomos na atividade deles na praça, isso foi início dos anos 80 , e a gente entrou pro movimento. Começamos a freqüentar Palmares e estamos até hoje. Eu fui pro coletivo de mulheres negras. Depois a gente fundou o nosso grupo, se organizou mais, registrou o grupo, e começamos um trabalho mais intenso. Atualmente a gente trabalha em torno de 60 pessoas. É um trabalho bem bacana, porque a gente consegue dançar, fazer trabalho em escolas, palestras em universidades. Escola desde o fundamental até as universidades falando não só do jongo, mas como da cultura negra e o contexto que a gente vive atualmente. Eu trabalho nessa parte com minhas irmãs, que é a Meméia e a Gracinha e eu tenho também outros professores no grupo: Neide faz essa parte... Então, é um trabalho que cresceu.

\section{$\mathrm{P} / 1$ : E a missão, qual é?}

R: É valorizar a nossa história, dar auto-estima pro nosso pessoal. Igual eu falei: a gente precisa trabalhar muito a questão da auto-estima por causa desse processo da sociedade de sempre fazer tudo pra inferiorizar. Algumas pessoas nossas aceitaram essas condições. Então a gente trabalha isso, porque a gente tem direito a tudo, enquanto brasileiros que somos. A gente vai pra dentro das escolas, principalmente trabalha com crianças, porque nada nesse país valoriza o negro, nada. É televisão, é revista, nada, nada valoriza. Algumas coisas que aparecem na mídia é porque a gente está por trás brigando. A gente movimenta o negro, briga muito pra que a mídia ponha a nossa cara nas coisas. Os nossos heróis negros Estão indo pra dentro das escolas, porque a gente está levando. Na minha época que eu estudei, nem é tão longe assim, não se falava em Zumbi dos Palmares. A gente tem aqui a história de Manuel Congo que foi um negro que foi enforcado porque também fez uma rebelião de 400 negros reunidos nas fazendas. Agora que a gente está brigando, tem que trabalhar esse nome, é um herói nacional! Inclusive hoje tá tendo uma festa aqui no memorial, que tem muitas pessoas de fora, muitos negros; a gente tem que reverenciar, porque naquela época, nas condições que os negros viviam, ele conseguir fazer uma rebelião, reunir 400 negros e tal, poxa, e com essa mulher junto, a Mariana. A gente teve até 
a felicidade que o prefeito César Maia do Rio de Janeiro inaugurou esse ano uma maternidade com o nome dela no Rio. Pra gente foi um avanço assim muito grande, porque se precisa trabalhar o nome dessa mulher.

$\mathrm{P} / 1$ : Você podia contar um poquinho a história do jongo, como é que ele se divulga e como é que ele começa.

R: Os negros trabalhavam de sol a sol, eles não podiam se comunicar, já se trabalhava a questão de misturar as etnias pra que não houvesse comunicação. Os dialetos eram diferentes. Eu costumo até falar que a gente vive até hoje porque o nosso povo foi muito guerreiro mesmo, porque tudo era contra. E o único momento que eles tinham era à noite. Sempre acendia uma fogueira em frente à senzala e eles batiam os tambores. Esses tambores são confeccionados em tronco de árvores - nosso inclusive é feito de imbaúba - e nesse momento é que eles se comunicavam. Então eles armavam as fugas, ataques às fazendas tudo através da música e através da dança. Então, pro feitor ou pro fazendeiro eles tavam dançando, bebendo aguardente - também aguardente realmente bebiam, porque descobriu lá que a cachaça aquecia o corpo, fazia esquecer muitas coisas - então eles comunicavam através dos "pontos". Um jongueiro, no caso, o escravo, ele cantava um ponto pro outro e o outro respondia e a gente mantém essa tradição até hoje. Inclusive a gente está com um trabalho em rede de preparar os jovens, de estar incentivando os jovens a praticar isso, essa forma de diálogo, porque algumas comunidades estão resgatando o jongo. Então, está se cantando muitos pontos repetidos. A gente pode estar trabalhando, fazendo oficina pra despertar isso no jovem de estar fazendo esses pontos. Agora, atualmente, a gente ainda reverencia a figura do preto velho nas nossas rodas, porque até um tempo atrás criança não dançava jongo. $\mathrm{Na}$ minha época mesmo a gente não podia dançar, era só os mais velhos mesmo, de 60 anos pra lá, mas a gente ficava em volta, ali, sabe, a gente não entrava na roda, mas tava ali em volta, e na minha casa nós começamos a dançar mais cedo porque na minha casa todo mundo é alto, então a gente conseguiu ir pra roda mais cedo. Mas tem jongueiros que não permitem que a criança dance. A gente faz esse trabalho porque a gente precisa preservar a dança, trabalhar muito a criança. Mas a tradição era os mais velhos que dançavam. Exatamente por causa disso, por causa dessa comunicação, de um jongueiro cantar ponto e o outro ter que desatar. O nosso povo sempre também trabalhou o candomblé. Hoje em dia a gente trabalha a umbanda também, mas naquela época eram os orixás, e eles tinham conhecimento dessa força e tal e isso também rolava na hora, porque era o momento que eles tinham. Então ou fazia tudo na roda ali ou não podia fazer outra hora, então era o momento. Então era muito forte a roda de jongo e ela é ainda até hoje. Quando a gente vai pros quilombos, a gente dança e tal, a gente sente a força que tem um tambor. $\mathrm{O}$ tambor, pra comunidade negra, ele fala muito. Não sei se vocês tiveram oportunidade de participar da roda que nós fizemos na escola ontem. 
$\mathrm{P} / 2$ : Em que escola vocês estavam trabalhando?

$\mathrm{R}$ : Ah, foi linda a roda, nós tivemos ali a tia Marina de Barra do Piraí que já é uma senhora de bastante idade, jongueira; a tia Maria do Jongo da Serrinha, de vários tambores. Nossa! A gente também estava na terra, o espaço lá era terra e tinha uma mangueira, também. Então, tinha um axé muito forte ali, foi linda a roda, muito bonita.

$\mathrm{P} / 2$ : Deixa eu te perguntar uma coisa, você fala assim que o jongueiro canta um ponto e o outro desata.

R: Isso.

$\mathrm{P} / 1$ : $\mathrm{O}$ que é isso?

R: Um exemplo assim, eu estou vendo uma coisa em você, ou eu sei alguma coisa da pessoa, de você, eu canto um ponto pra você, você fala "tá cantando isso pra mim", entendeu? Aí eu tenho que te dar a resposta. É como se fosse um desafio, entendeu? Aí eu tenho que te dar a resposta. É muito bonito, muito legal mesmo. E tem também na parte da brincadeira, igual eu falei. Aí eu estou vendo a sua blusa azul, então eu vou cantar um ponto porque você está de blusa azul, mas tem também a questão, eles falam dormenta, que é um jongueiro debatendo com o outro, quem canta o ponto mais forte. É bacana a disputa e o coro, as pessoas que estão em volta fazem o coro, repete. Normalmente a gente repete a parte final do ponto. Aí, você dança a noite inteira, até de manhã, é muito bom. Atualmente nós criamos a rede memória do jongo e Caxambu, numa parceria com os professores da UFE e a gente está agora com 18 comunidades, algumas, que foram resgatadas e outras tradicionais como a nossa, o jongo de São José, no quilombo São José; Valença, o jongo dos quilombos de Angra dos Reis; Parati Campinho, tem Guaratinguetá, Piquete, inclusive a gente vai tá dia 31 de agosto, um e dois de setembro no Piquete que é São Paulo, perto de Lorena, fazendo o $12^{\circ}$ Encontro de Jongueiros, vão ser dois dias de muita dança. Se vocês quiserem aparecer lá, vai ter muitos mestres, é bem bacana, nenhum grupo é igual ao outro, sempre tem uma variação de grupo pra grupo e o jongo é uma manifestação que é do Sudeste, foi tombado como patrimônio histórico em 2005. E através do jongo da Serrinha, que o mestre Darci - ele faleceu em 2000 e, 2001 - fez um trabalho! Exigiu a vida inteira dele, trabalhando jongo e ele fez um trabalho muito legal que colocou outros instrumentos no jongo, foi pra dentro das universidades do Rio de Janeiro, foi pro palco e deu uma outra cara, mas é um jongo bonito: o jongo da Serrinha. E eles mantêm isso até hoje e através do jongo da Serrinha foi que a gente passou a ter mais visibilidade. E agora no governo do Lula, o Gilberto Gil ele está dando muita ênfase pra cultura popular, então a gente também está conseguindo alguns projetos e os pontos de cultura. Está assim sendo bem bacana o Ministério da Cultura, porque tá 
olhando mais pra cultura popular, porque as comunidades jongueiras, por exemplo, todas são muito pobres e o pessoal mantém a tradição, porque é uma coisa nossa, a gente gosta de dançar, tem prazer em fazer isso. Não só a gente, como as folias de reis, as congadas e agora a gente tá tendo a oportunidade de está dando assim alguma coisa melhor pro nosso povo, com os pontos de cultura acaba os nossos jovens tendo acesso à multimídia. A gente está conseguindo ter acesso a alguns aparelhos que a gente não teria nunca se não fosse essa oportunidade, então tá sendo muito bom.

$\mathrm{P} / 1$ : Eu sei que é quase impossível, mas teria como cantar um ponto só pra gente ter uma idéia do que é isso?

R: Ah, tá, olha só, como eu falei, o jongo de Pinheiral procura manter a tradição e é bonito o nosso jongo de se ver. Eu escuto isso eu gosto, eu adoro, gosto de dançar e é legal, porque as pessoas querem dançar com a gente. Sempre que faz apresentação, no final, a gente chama as pessoas pra participarem. Tem um público grande que gosta do nosso jongo, porque realmente ele tem uma melodia. Eu não entendo assim muito de música, mas maestros, o pessoal da música fala isso. Ele é tocado em dois tambores, que é o tambor grande e o candongueiro e nós temos um bastão, um pedaço de madeira que tem o nome de macuco. Esse pedaço de madeira faz o contratempo entre os dois tambores e o nosso jongo é o único que tem isso. Ele bate do lado do tambor grande, faz o contratempo, então dá um som bem bacana e os nossos pontos também são bem bonitos. Ah, é muito legal os nossos pontos, a melodia, o jeito de cantar. Eu vou cantar um ponto que em todo lugar que a gente se apresenta as pessoas gostam desse ponto. Não tem a voz que é muito boa, mas a gente canta. É assim ó: A morena me pediu laço de fita pra cintura, ai eu mandei cordão de ouro, laço de fita não atura. Oi, a morena me pediu laço de fita prá cintura, ai eu mandei cordão de ouro, laço de fita não atura. Oi, Irere, oi Irere, oi Irere, oi Irere. Sabe, são vários pontos pra várias situações. A gente tem um ponto, que lá na minha cidade tem um bairro que chama Três Poços, então, a gente tem um ponto que é assim: No caminho de Três Poços tem um coco madurando, eu quero apanhá coco, catinguelê tá me olhando. No caminho de Três Poços tem um coco madurando, eu quero apanhá coco, catinguelê tá me olhando. Foi um jongueiro que cantou pra uma moça, estava lá na roda, ela mora lá nesse bairro, e ele estava paquerando ela e tal. Ele queria conversar, mas não podia, os pais da menina estavam lá. Então, ele cantou esse ponto. Tem um também, que o rio Paraíba do Sul passa em Pinheiral, então, no passado apareceu alguma família de jacarés lá no rio e foi uma festa, porque lá não tem jacaré lá no rio. Então, no quintal lá do povo, menino, foi jornal, foi uma semana de confusão por causa do jacaré. Aí, o meu colega lá, o jongueiro lá fez um ponto também: No varjão em Pinheiral baixo, no varjão, no varjão em Pinheiral jacaré tá dando cria, oi jacaré tá dando cria, no varjão em Pinheiral jacaré tá dando cria, oi jacaré tá dando cria, só quem viu pode falá, jacaré tá dando cria, oi jacaré tá dando cria. Aí sabe, também faz o maior sucesso lá na região, porque o jacaré foi famoso lá. Então, o jongo é assim: se vê alguma coisa você cria o ponto e a gente vai cantando e as pessoas 
que estão em volta, que é em círculo a formação, repete o coro.

\section{$\mathrm{P} / 1$ : E quando Ação Griô entrou na sua vida?}

R: Bom, também foi muito interessante. $\mathrm{O}$ ano passado eu estava no Rio de Janeiro, organizando o $11^{\circ}$ Encontro de Jongueiros, que foi no Quilombo São José da Serra. Aí, a Lílian, o Márcio, eles estavam lá no Ministério da Cultura, lá no Teatro Capanema, fazendo uma oficina Ação Griô que eles estavam trazendo pro Rio de Janeiro. Aí, me convidaram. Foi aquela coisa. "Vai pra lá pra você conhecer e tal" e eu não pude ir, porque eu estava nessa coordenação, mas a Celinha foi, do PIM [Programa de Integração pela Música], aí quando a Célia voltou, trouxe o material pra mim: "Fatinha, você tem que entrar, porque é a sua cara, você tem que entrar e tal, não sei o que", aí quando o edital veio o Santini pra cá, que ele coordena a Ação Griô aqui no Estado, e me chamaram: "Ah Fatinha, vem pra cá pra gente montar um projeto" Então, como nós somos seis pontos de cultura aqui na região, convidou todos os pontos. Nós viemos pra cá, montamos o projeto. Aí foi aprovado, foi um sucesso, porque a gente vai está trabalhando em quatro municípios. A gente vai fazer isso nas escolas durante um ano, levando a cultura popular pras escolas. Aí, na hora que a gente estava montando o projeto, estava lá: "mestre daqui, mestre dali" e estavam colocando só homens, todas as manifestações que a gente ia trabalhar era só homem. Aí, "gente do céu, mas não vai entrar nenhuma mulher e tal?" Tem a questão da idade, que tem que ter de 50 pra cima ou estar pra lá de 60, E aí "Fatinha, você não tem lá nenhuma mulher que possa vir?" $E$ alguém perguntou pra mim quantos anos eu tinha, e eu tive que falar que eu tinha 50 anos. "Ah, então é você mesmo quem vai”, e fui pra ser mestre de honra. E está sendo bem legal, porque aí ficou só eu de mulher aqui na região, porque os outros são homens. Está sendo bem bacana o trabalho.

\section{$\mathrm{P} / 1$ : Conta um pouco como é que está sendo esse trabalho do griô?}

R: A gente está trabalhando desde março e nós vamos levar esse trabalho pra dentro das escolas. Então a gente já trabalhou em quatro municípios, inclusive sábado passado foi lá em Pinheiral. Fomos trabalhar a Caninha Verde, o Jongo, o Calango, a Folia de Reis, e o André vai ser o griô aprendiz, então, ele vai contar a história do vale. A gente vai abordar outras manifestações que tem no vale, e ele vai contar a história e nós vamos falar de cada manifestação pras crianças. A gente já montou um plano de trabalho pra ensinar as nossas batidas de tambor; o seu Filhinho, que é da Caninha Verde, que tem que trabalhar com aqueles bastões, que faz aquela dança tipo mineiro pau, vai ensinar isso. Ele é uma gracinha, ele tem uma facilidade muito grande pra versar, sabe, então, você fala uma palavra e ele já emenda ela rimando. Ele vai com a Caninha Verde, e o seu Julião com o Calango e o seu Agostinho com a Folia de Reis de Valença. Então, a gente também teve que aprender as manifestações. Eu no caso, sou do jongo, estou aprendendo manifestações dele pra na hora da oficina a gente 
ajudar e eles também estão aprendendo o jongo pra poder a gente trabalhar tudo junto e passar isso pras crianças. Então a gente vai pra escola, vai chegar na escola assim em forma de cortejo, até pra chamar a atenção dos jovens, tal. O André vai contar a história do Vale, das manifestações e depois a gente vai fazer as oficinas. A gente vai fazer isso durante um ano nas escolas. Acho que vai ser bem interessante, porque eu, no meu caso, já trabalho com escolas. Mês de maio e novembro, nós fazemos muitas apresentações em escolas e universidades, muitas. A gente é bastante solicitado, então já existe esse trabalho. É legal porque o jovem, nas oficinas, eles participam, querem bater, querem aprender a dança e às vezes a gente vai em escolas de classe média alta e tem assim uma aceitação bem legal, porque os professores preparam os alunos, contam as histórias, e quando a gente chega lá, eles já têm mais ou menos a noção. Não conhecem, mas já têm a noção, e a gente faz a nossa parte: conta a história do jongo específica, depois a gente vai pra dança. Então, eles sempre estão com perguntas pra gente e normalmente os professores dão retorno, que depois eles fazem uma outra avaliação e dão retorno pra gente. Então, tá sendo muito bom esse trabalho nosso nas escolas. Eu, no meu caso, tenho uma certa experiência do meu grupo disso, porque a gente já tá fazendo isso há algum tempo. E aí, a Ação Griô só veio somar. Vai ser muito bom, a gente tem aqui em julho, na última semana de julho, esse ano vão ser dez dias, porque o festival vai coincidir com os Jogos Panamericanos - normalmente são as últimas duas semanas de julho - a gente tem o festival Vale do Café, que acontece aqui em Vassouras e em alguns municípios, onde é trabalhada a música clássica e a cultura popular. Então, a gente faz a cultura popular na cidade, nas ruas da cidade, cortejo. É muito bacana; vem muito turista e é trabalhada a música clássica nas igrejas e nas fazendas, porque aqui tem muitas fazendas históricas. Então esse festival também consegue atingir um público muito grande com a manifestação popular. $\mathrm{O}$ nosso trabalho está sendo esse.

\section{P/1: E qual é a importância pra você da Ação Griô?}

R: Nossa! Olha, é muito importante, porque a gente dentro das comunidades tem um pouco de dificuldade em estar registrando a vivência dos nossos, dos nossos velhos, vamos dizer assim. No caso da tia Marina que estava aqui ontem, do jongo de Barro, que é de Barra do Piraí, a gente tem pouco registro da tia Marina e agora com essa Ação Griô a gente vai poder colher mais coisa dela, que vai servir pra gente e vai servir pra quem está vindo. A gente tinha dificuldade em fazer isso, então, essa Ação Griô vai nos possibilitar a estar mais próximo das pessoas idosas, das comunidades e estar pegando isso deles e trazendo eles. A tia Marina é a segunda vez que ela vem pra cá, pra ação, e é uma pessoa que nem sai de casa. A gente está conseguindo trazer essas pessoas pro meio da gente, passando experiência pros jovens, então está sendo muito bacana.

$\mathrm{P} / 2$ : E como que esses jovens recebem? 
R: Nossa, com o maior carinho, o maior respeito; fazem perguntas e a gente está conseguindo, porque eu vejo os jovens hoje em dia muito alienados. É computador, lá em casa mesmo é música de funk nas alturas, não sei o que, não sei o que lá, só que lá em casa tem uma diferença, porque a hora que o tambor começa a bater todo mundo vai pro tambor, e outros jovens não têm essa oportunidade. Então lá em casa ainda dá pra dividir o negócio. Pra eles está sendo diferente, é muito bacana. Aqui no PIM, eles trabalham jovens ali. Quando a gente está com oficina ali, todo mundo larga os instrumentos deles e vai pra lá pro tambor. Então eu vejo o interesse deles em aprender a dançar, a cantar. Está sendo bacana.

$\mathrm{P} / 2$ : Deixa eu te perguntar uma coisa, não sei se é uma pergunta boba, mas ontem de manhã naquela roda, lá no casarão ali no paço, teve essa coisa de uma pessoa bater um ponto e a outra responder pegando o chapéu. E teve alguns jovens que deram um outro tom ali, de rap. Tudo acontece?

R: É acontece.

\section{$\mathrm{P} / 2$ : $\mathrm{O}$ que você acha?}

$\mathrm{R}$ : Acontece, porque normalmente a gente vai assim pra encontro, igual ali, lá no quilombo São José, que a gente tava sábado dia 12, e você vê tudo. Você vê o funk, você vê o rap, você vê o samba de roda, o jongo, forró, tudo ao mesmo tempo, entendeu? Então também a gente tem essa facilidade de trabalhar tudo isso e o hip-hop a gente está trabalhando muito, está procurando valorizar esse lado da música, porque também é uma coisa da cultura negra. Aqui, no Rio de Janeiro, a gente está trabalhando muito hip-hop. Então a gente traz esses caras, as meninas, tanto faz a parte da cultura popular quanto faz a parte deles. A gente consegue trabalhar com eles e eles com a gente. E tem um grupo em Volta Redonda que chama Bloco de Concreto, eles são tudo doidão, assim, eles tão até em Recife fazendo uma, um intercâmbio, vão ficar dois meses lá. Mas eles fazem a cultura popular com a gente, então, quando eles forem, o que eles levaram de cultura popular pra Recife foi os nossos materiais do jongo. A gente consegue trabalhar junto. É ótimo isso, acho bom, porque a gente na cultura popular, a gente tem uma história, sabe, a gente tem uma história que é muito forte e o jovem hoje em dia, ele não tem acesso a isso. Eu trabalhei na Prefeitura de Pinheiral, é até um outro ponto de cultura que tem aqui na região, é Associação dos Sertanejos, eles fazem música de viola, música de raiz e nós fomos com esse projeto pra dentro das escolas; trabalhei em sete escolas municipais com isso. Então a gente chegava lá: "o jovem não vai se interessar por isso". Qual foi a surpresa nossa? Jovem de lá ir cantar essas músicas de raiz junto com eles, lá as violas e os meninos cantando, foi lindo, porque a gente pensa que não estão nem aí pra música de viola e tal, porque não é muito forte aqui na nossa região, e a nossa surpresa foi que muitos 
jovens conhecem porque a família tem essa experiência. Então cantaram, e foi lindo o trabalho, e a mesma coisa acontece com a gente quando vai pra dançar, o jovem a gente chama, a gente faz uma meia hora, 20 minutos de apresentação pra mostrar a dança, o nosso trabalho e depois a gente convida as pessoas pra participarem. Todo mundo quer dançá. Muito bom.

$\mathrm{P} / 1$ : E como é que o mestre passa pro aprendiz os conhecimentos? É com causos, com música?

R: No meu caso, o jongo, eu sempre mostro como é que dança, o que tem pra fazer, o básico pra entrar na roda e dançar e os nossos batedores mostram as batidas. A gente vai e mostra, porque a batida do jongo é diferente, inclusive de uma comunidade pra outra tem diferença. Então a gente dança e depois a faz um rodão, aí todo mundo dança. As outras manifestações são a mesma coisa. E a gente conta também a história que a gente já viveu, história que passa de geração pra geração. Igual quando rola uma história na roda de jongo, de jongueiros, todo mundo conta essa história, que antigamente, na época dos jongueiros bons mesmo, que o jongueiro cantou um ponto lá que nasceu uma bananeira na roda de jongo e que deu cacho de banana, a banana madurou e todo mundo que tava na roda comeu a banana, todo mundo conta essa história. Então, sabe, é possível que isso tenha acontecido mesmo, porque eu no meu caso, por exemplo, eu conheci assim vários jongueiros que seriam capazes de fazer coisas dessas, que era jongueiro, jongueiro mesmo, e além de jongueiro tinha uma religião. Então, essas pessoas que são fortes dentro das religiões afro conseguem fazer muitas coisas, então é possível que isso tenha acontecido. Agora, eu vivenciar, nunca vivenciei não. A única coisa que eu vi quando era criança era o jongueiro passar nas brasas sem queimar o pé; isso eu vi, várias vezes na noite de São João que eles fazem isso. A gente faz um fogueirão, aquela brasa lá pra meia-noite, na madrugada, e os caras passam descalço na fogueira e não queimam o pé, isso aí eu vi várias vezes. Então, agora essa história da bananeira, vários jongueiros contam, é muito interessante, mas é possível que tenha acontecido, não é impossível não. Porque o jongo, ele é uma dança, mas ele também tem assim muitos preceitos. A gente teve um jongueiro lá, o seu Zé Cabiúna que ele ficou com a gente muitos anos e era um preto lindo, lindo mesmo, alto, tinha um rosto muito bonito, bem preto ele era muito elegante; ele só ia prás rodas de jongo de terno branco, e nossa, dançava bonito, a dança dele era linda, cantava muito. A gente tem o filho dele, que é um mestre também, a gente fala que ele é o único no Brasil: esse faz ponto na hora, e tem o jeito de cantar igual ao do pai dele. Só que ele tá com problema de alcoolismo então, ele quase não tem saído com a gente. É novo ainda, a gente está fazendo um trabalho pra ver se recupera ele, porque ele é jongueiro mesmo. E, então, o seu Zé, aquele jeito, aquele estilo dele de dançar tinha a maior moral mesmo no meio dos jongueiros e a gente aprendeu a dançar com ele. Então, ele passou algumas coisas pra gente, algumas coisas que a gente faz nas rodas, que precisa fazer nas rodas de jongo. Então, alguns rituais, algumas coisas, 
mas quem é jongueiro velho é que sabe. A gente quando vai dançar no terreiro dos outros, a gente tem alguns pontos que a gente não pode cantar, que às vezes a gente canta, mas é ponto que se eu tiver na casa de outro companheiro eu não posso cantar, porque eu estou, mexendo com o dono da casa, com o chefe lá do terreiro. Então, o pessoal mais jovem nosso a gente já falou "ó vocês prestem atenção nos pontos que vocês vão cantar, hein?" porque a gente não pode, vai mexer lá. Então, tem muitas coisas, eu costumo falar, quando a gente está na reunião da rede, e falam que o pessoal que tá resgatando o jongo, eu falo - "Gente, vocês precisam conhecer a história do jongo de vocês, lá de trás, porque vem cantando de qualquer forma, assim, e não pode." - então, tem essas coisas de negros. Aí, alguma coisa a gente pode passar, outras a gente não pode passar. Eu no meu caso, eu que já estou na frente, vou passar lá pra frente. Algumas coisas eu já passo pro meu pessoal que eu aprendi com o seu Zé Cabiúna. Já tinha a Oscarina também, que era jongueira velha, gente conseguiu pegar poucas coisas, poucas, mas a gente vai.

\section{$\mathrm{P} / 1$ : O seu aprendizado foi com os seus pais, na família mesmo?}

R: Não, não foi na família, porque o pessoal da minha mãe é de Minas, e Minas o forte lá é congada e Moçambique que são próximos do jongo. Do lado do meu pai que é jongo, mas eu aprendi, a gente aprendeu mesmo, foi em Pinheral, porque lá em Pinheiral sempre se dançou jongo, lá tinha uma festa junina que começava em Santo Antonio, 13 de junho e só terminava em São Pedro e era direto, a semana toda. Então, eles dançavam toda noite, os negros lá, dançava toda noite, aquilo ia até de madrugada e a gente ficava lá. Então, a gente aprendeu já da comunidade mesmo.

$\mathrm{P} / 1$ : Tem algum outro caso igual aquele da bananeira que você pode contar pra gente?

$\mathrm{R}$ : Ah! tem, tem vários casos. Esse eu cheguei a presenciar: normalmente a gente dança muito no inverno, festa de rua, então o pessoal bebe muito; festa de coisa assim, a gente sempre tem o banco, as cadeiras, sempre a gente deixa uma garrafa de cachaça lá perto, porque o pessoal bebe mesmo, isso já vem lá de trás. Mas tem pessoas que bebem fora da roda, depois entra na roda e quer dançar de qualquer jeito. Tem sempre o pessoal que entrava na roda pra bagunçar a roda, então o seu José cantava uns pontos lá e eles caíam no chão. Todo mundo ia caindo, isso a gente viu! Ele cantava um ponto assim, "Galo cantô, inda é madrugada, jongo não é reza e nego tá de caçoada." - na hora que ele cantava esse ponto, ah! meu filho, caía nego que estava na roda, aí depois puxava outros e o negócio pegava. Nego não voltava mais. Tinha gente de rolar e saía fora da roda. E o seu Zé era interessante, esse seu Zé Cabiúna, ele podia beber a cachaça que estava no tambor, que fica lá na garrafa, mas se ele saísse dali e fosse beber em barracas de festas de rua ou em bar assim, ele ficava bêbado, passava até mal. Ele tinha que ter a cachaça dele no tambor. E um outro jongo que eu vivi com 
ele também, que eu também guardei isso: nós fomos convidados pra fazer uma festa lá em Arrozal, dançar numa festa, aí nós fomos. Lá em Arrozal tem jongueiros, tanto que agora, dois anos atrás eles conseguiram montar o grupo. A gente sempre dançou com eles lá, o jongo deles é até semelhante ao nosso por causa disso. Aí o nosso jongo não firmava de jeito nenhum, o seu Zé estava cantando um ponto lá e o jongo não firmava, porque, igual ontem, eu falei pra vocês, todas as duas rodas, tanto a que a gente fez no colégio, quanto as que a gente fez na praça, a roda tava firme, tava boa, tinha axé naquela roda ali, e lá nesse jongo não. Porque o jongueiro canta o ponto, a gente, que está em volta não consegue pegar a toada pra responder, e tem que responder, porque pra afirmar o ponto. E aquilo não dava certo de jeito nenhum. E seu Zé canta ponto, aí ele falou assim, aí ele lembrou dum jongueiro e falou "ó", chamou pro dono, falou "ó, vocês convidaram fulano de tal?" - eu nem lembro o nome do homem mais, eu era criança, eu era adolescente nessa época - "não, a gente não convidou não", um jongueiro velho, lá, da cidade, dum lugar lá, "não, a gente num convidou não", ele falou “ó, esse jogueiro, fulano, tá amarrando meu ponto", e a casa do homem ficava numa subida mais pra cima assim de onde a gente tava. Aí o seu Zé começou a cantar ponto chamando o homem pra roda, e o homem não veio, e seu Zé tá cantando ponto e chamando o homem pra roda e o homem não veio...eu sei que aconteceu que o seu Zé acabou bebendo, saindo da roda, bebeu, ficou bêbado, não teve jongo aquele dia, não conseguiu dançar; nós viemos embora, seu Zé passando mal na Kombi, lembro que a gente tava de Kombi, e não dançamos. Isso eu vivi lá, esse negócio, a gente não dançou. Então o jongo também tem dessas coisas. A gente brinca, a gente dança, tudo, mas a gente, principalmente quando a gente sai respeita muito. Meu pessoal também respeita muito jongueiro velho, porque a sabedoria está toda nele. Igual a gente vê a tia Marina lá: uma senhora, não está nem agüentando andar mais. A gente botou cadeira lá pra ela sentar e ela cantou ali. Quer dizer, tem toda a sabedoria, está nela, toda. Então a gente tem que respeitar muito, porque o jongo é uma coisa de diversão, mas ele também tem suas peculiaridades, um negócio legal, bonito da gente viver, é a nossa história, a nossa história está ali.

\section{$\mathrm{P} / 2$ : Quando você fala que um jongo tem muito axé, o que quer dizer isso?}

R: Tem força. O meu tambor ele é feito no tronco da imbaúba, e o tambor grande é feito na barrica, aquelas barricas de vinho, então ele é feito de couro cru, pra o couro esticar a gente tem que aquecer ele na fogueira. Bota ele perto do fogo, aí o couro estica. O nosso tambor fala alto pra caramba, de longe você ouve o som dele, e tem tambor que não fala. Tem tambor que não fala, por quê? Porque a gente tem toda uma preparação com o tambor. Tambor é tudo pra gente. Tambor é tudo. Inclusive ele bebe junto com a gente, a gente tem que dar cachaça pro tambor. Tem comunidades que não fazes isso, não saúdam o tambor. Aí às vezes a gente vai saudar o tambor, a gente saúda o tambor antes de começar o jongo, quando a gente vai entrar na roda, aí tem gente que está vendo assim, “ah, é macumba”, e não é, é porque a gente faz 
reverência ao tambor, o tambor é tudo pra gente, não tem nada a ver com santo, com macumba, não tem nada a ver. É porque ele é o rei ali do negócio. Então sempre que a gente entra na roda do jongo a gente vai lá saravá o tambor. É, mas aí tem gente falando: "É macumba!" E não tem nada a ver com a macumba, é porque o tambor ele é muito forte, não só no jongo, em outras manifestações também. Vocês podem ver, por exemplo, nós brasileiros, o tambor começa a bater ele mexe com todo mundo. Você pode ser evangélico, pode ser o que for lá que não adianta: o tambor bateu... ele fala...Tem muito, muito axé mesmo o tambor. A gente procura sempre dançar na terra, porque a terra, também é forte, a gente não gosta muito de dançar em lugar coberto. O seu Zé, quando falava com ele que a gente ia dançar assim em palco, em lugar fechado, ele ficava bravo, não gostava. Jongo tem que ser no terreiro. Mas tudo por causa desses preceitos que existem. A fogueira, também, sempre que a gente pode, se puder fazer uma fogueira, faz uma fogueira, porque a fogueira também é muito forte. Faz parte do contexto aonde tem a dança do jongo. A gente também gosta de dançar descalço. Dançar de calça comprida? Nossa, ele ficava bravo. Mulher dançar de calça comprida. Que nem aquelas negras velhas, lá, antigamente elas dançavam com aquela saiona rodada, assim, era muito bonito aquelas preta velha. A gente ia dançar de calça comprida, ele ficava muito bravo. Falava: "A senhora parece dois homens dançando!”, O jongo é isso! Aí a gente dança até amanhecer o dia. Ninguém cansa; normalmente tem uma comida por perto, sempre a gente faz canjiquinha, faz outra comida lá, angu à baiana, alguma coisa assim que todo mundo come, bebe, bebida rola mesmo, mas é muito bom jongo de terreiro.

\section{P/1 -Tem dia que o tambor não tá querendo tocar?}

R: Não, não, o tambor sempre bate. $\mathrm{O}$ que acontece, às vezes, que a gente observa, são lugares da gente chegar e o jongo não ficar bom por causa do lugar. Lá em Pinheiral, por exemplo, tem determinados lugares que a gente não gosta de dançar, porque a gente sabe que o jongo não fica bom. Ou começa a entrar pessoas que não tem nada a ver e acaba a gente se perdendo. $O$ negócio não fica bom, não fica com essa força, igual a gente pôde presenciar ontem aqui. Tem determinados lugares que se vai que o jongo não fica bom. Amarra assim duma tal forma... a gente sente, a gente que já dança, sente. "Gente, esse ponto tá amarrado", então a gente, sabe. Às vezes pessoas que sabem como é que faz isso, porque eu não sei fazer isso no jongo dos outros, eu não aprendi a fazer isso, mas tem gente que sabe fazer. Aí então tem determinados lugares que a gente vai que o jongo não fica bom, assim, fica aquele negócio pesado, mas é por causa do lugar, não pelo tambor. É por causa do lugar. E mais, a gente presencia assim mais pelo lugar, já, sabe que o negócio não vai prestar. Aí quando é assim a gente canta só um pouquinho, cai fora. "Ah não, vamos fechar, porque..."

$\mathrm{P} / 1$ : Os griô trabalham com a tradição oral, e tem as crianças que trabalham na educação formal no colégio. Como é que você consegue fazer a ligação, do formal com 
o oral?

R: Ué, é assim mesmo, é através da música mesmo, sabe. A gente passa as nossas músicas pras crianças, eles aprendem primeiro a música, porque a nossa tradição ela é passada mesmo de forma oral, não tem outra forma, outro jeito. Principalmente a tradição afro. $\mathrm{E}$ às vezes quando a gente trabalha, também, a figura da rezadeira, que a gente sempre tem - o seu Julião, por exemplo, que ele trabalha o calango, ele é rezador - então ele vai, ele fala das ervas, das curas com as ervas, e tal, a família da criança tem até alguma coisa em casa que serve pra isso, serve pra aquilo. Então a gente trabalha isso lá, também, e é tudo através da comunicação; vai e pergunta à criança "ah, você conhece",, ou "sua vó tem", Interior normalmente tem uma horta, mas às vezes as pessoas não conhecem muito a questão de ervas, então quando a gente está com a figura do rezador, consegue trabalhar essa parte também, mas é tudo interagindo com a criança, procurando mostrar o que ela tem, que ela pode ter acesso do conhecimento da gente. Passando pra eles, ele podem trabalhar com aquilo.

\section{P/1: Qual é o significado, pra você, de ser uma mestre griô?}

$\mathrm{R}$ : Ah, tá assim sendo muito legal. Como aqui nesse encontro que a gente está vivendo: eu revi pessoas aqui que eu já tive contato alguns anos atrás, há muito tempo que não via. Quando eu fazia parte do coletivo de mulheres negras eu encontrei com a Maria Moura, que é uma senhora de candomblé que tem assim uma religiosidade muito profunda e é mestre greô, inclusive lá da Mangueira. Então a gente está em contato com essas pessoas. A tia Maria do jongo, a tia Maria tenho mais contato com ela, que é uma pessoa que sabe tudo de jongo, é uma pessoa maravilhosa. Então a gente cresce junto com eles, isso é crescimento mesmo. O seu Filinho, nossa, eu conheci seu Filinho tem três anos, aqui no cortejo do festival Vale do Café, e a gente já gostou dele, é uma gracinha. E agora, trabalhando com ele, eu que estou mais diariamente com ele, que pessoa maravilhosa! O homem tem 81 anos, mas ele tem uma experiência de vida tão grande, e tudo que ele fala você aproveita, tem sentido. Então é muito bom pra gente conviver com essas pessoas mais de idade. A minha mãe tem 73 anos, mas ela é uma mulher assim bonita, ela não tem uma ruga e é uma preta muito bonita - ela dança com a gente também - e a minha mãe tem uma experiência de vida muito grande. Nossa, as histórias que ela conta dá um livro. Pela experiência que ela viveu em Minas, na infância dela, parte dela lá; depois veio adolescente pra Barra Mansa, e essas histórias de família...a história da minha família é muito rica culturalmente. $\mathrm{O}$ meu bisavô, que era avô da minha mãe, ele era um negro, a minha mãe conta, que na época que ele viveu ele era um grande conhecedor de tudo. Lá no terreno onde eles moravam ele tinha plantação de tudo lá, conhecia tudo, e moravam na roça, mas ele ia pra cidade comercializar. Gente do céu. Minha mãe conta pra gente a história da família da parte dela, que a bisavó dela era índia e ela trabalhava com tear. Então ela fazia uns panos, tecia o algodão, e eles tingiam e eles faziam a roupa, as 
roupas deles, lá, na casa; e o avô da minha mãe, ele sabia comercializar, entendia tudo de plantação, então eles plantavam lá e ele ia pra cidade comercializar. Ela fala assim, entre o pessoal da cidade, que ele tinha uma situação mais ou menos porque ele tinha esse tino, sabia fazer esse tipo de trabalho. E fora a questão de ervas, de escultura, era um músico também, tocava um violão, e o Moçambique, porque no Moçambique tem rei e rainha, essas coisa, então eles eram na festa de Nossa Senhora do Rosário, que é muito bonita lá na cidade. Só que depois a minha avó veio embora pra Barra Mansa, aí se perdeu um pouco disso, mas essa coisa de cultura, de música, isso vem de muito tempo na minha família, e na minha família todo mundo gosta. Lá em casa a gente mexe com tudo: com samba, com futebol, com jongo, tudo a gente está no meio, porque faz parte do nosso dia-a-dia. É legal, porque nas famílias africanas essas coisas fazem parte mesmo do cotidiano. Na África a gente sabe que tudo é junto, não tem "ah, vou sair daqui pra ir fazer", é tudo dentro da casa, da família, rola tudo, e a gente tem bem muito isso. A minha família tem essa parte de cultura, na culinária também, a gente trabalha muito a culinária afro que também vem de família. Minha avó foi grande cozinheira de hotel, meu pai trabalhou também em hotel, cozinha de hotel, cozinhava muito bem. E a gente teve bar, durante muitos anos. Aí todo mundo cozinha lá em casa por causa desse bar. E hoje, dentro do jongo a gente trabalha a culinária afro. Aí eu já trabalho com grupo inclusive a equipe da Ação Griô, no vale, nós recebemos eles lá no sábado passado. Foi uma festa, sabe? Foi uma festa, assim, porque o pessoal preparou muita coisa, e nós dançamos, e aprendemos um pouco da caninha verde do Seu Filhinho, ele ficou até muito bravo...vou contar essa história porque isso foi engraçado. O André falou assim: "Fatinha" - desde março que a gente está trabalhando na Ação Griô, e ele quer mostrar a caninha verde original dele, porque a que estava aqui ontem, que é a Davi Ferreiro, essa indústria que tem aqui, ele fala que é diferente da que ele sabe, só que a gente estava precisando de um sanfoneiro - agora que arrumou o sanfoneiro - pra pegar a toada dele, e a música dele, porque ele fala que é diferente daquela, e o jeito de pegar o bastão de dançar também. Aí eu falei assim: "André, então vamos fazer uma oficina lá em Pinheiral pra gente pegar". Aí arrumei os bastões, preparei meu pessoal lá pra poder fazer oficina com ele, só que tinha um pessoal do Rio que foi junto comigo aqui de Vassouras, e tinha outras pessoas de fora lá também. Aí o pessoal falou: "Vamos dividir então, fica uma parte fazendo oficina do jongo e uma parte fazendo oficina com seu Filinho." Só que o tambor começou a bater, e aí a gente estava lá fazendo a movimentação dos bastões, mas no ritmo do tambor, mas ele ficava bravo, gente! Mas ele ficou muito bravo: "Mas não pode! Vocês querendo fazer, trabalhar o bastão no som do jongo e não pode!" Mas a gente fazia no ritmo do jongo sem querer, a gente tava prestando atenção no que ele tava falando, mas quando você via já estava fazendo o movimento. Nossa, mas ele ficou muito bravo, foi muito engraçado isso! Aí eu falei: "André, a gente tem que fazer uma oficina só com ele, porque a gente até precisa aprender"... agora já apareceu o sanfoneiro, falei: "então temos que fazer uma oficina só com ele porque ele ficou muito chateado". Não deu certo. Ah, mas foi legal, então a questão 
da minha família é essa, é toda cultural, mesmo, sabe, a gente, assim, vive muito mesmo a tradição do mundo negro.

$\mathrm{P} / 2$ : Então, Fatinha, quais são os pratos que vêm da cultura afro?

R: Olha só, lá a gente trabalha a feijoada, trabalha a canjiquinha, o angu à baiana também a gente trabalha muito e os doces, cocada, pé de moleque, que a gente trabalha mais.

$\mathrm{P} / 2$ : $\mathrm{O}$ que caracteriza o angu à baiana?

R: Fala angu à baiana, mas ele é aqui do Rio de Janeiro. É o angu feito com fubá, e a gente faz um molho com miúdos de porco, rins, aqueles coisa de porco, os miúdos; faz o molho com tomate, pimentão, pimenta, cebola e põe por cima desse angu, aí serve, põe o angu no prato, angu molinho, e vem com a concha com aquele molho. Aqui no Rio de Janeiro todo mundo come isso. E aí a gente vende, faz um sucesso o nosso, e a canjiquinha também, o pessoal gosta muito.

$\mathrm{P} / 2$ : E é salgada?

R: Salgada, com costelinha de porco. A gente põe costelinha de porco, bacon, lingüiça, paio. E a gente põe cenoura ralada também no meio. Aí, na hora de servir a gente serve numas cumbucas, assim, e põe cheiro verde, cebolinha e salsa por cima. Vende muito mesmo, a gente faz uns panelão desse tamanho, vende tudo.

$\mathrm{P} / 2$ : É tipo um caldo?

R: É tipo um caldo grosso. Muito gostoso. No inverno, então, é tudo. Todo mundo gosta da canjiquinha. $\mathrm{E}$ a feijoada que a gente também faz. Mas assim, pra rua a gente vende mais é a canjiquinha e o angu à baiana, que é mais fácil pra preparar. E a feijoada a gente faz uma vez por mês, mas aí a gente vende os ingressos antes, os convites. Mas é bacana, as pessoas vão, gostam. E cocada e pé de moleque, que também a gente faz e vende.

$\mathrm{P} / 2$ : São de origem africana, mesmo.

R: É.

P/2: Que legal. Em Minas come muito canjiquinha, né?

R: Come, mas lá Minas é mais é pernil assado, torresmo. A gente vende muito também é feijão amigo. 


\section{$\mathrm{P} / 1$ : Feijão amigo?}

R: É, o que serviu ontem. Vocês foram na festa ontem? Então, tinha na festa aquele feijão que é engrossado com farinha, e aí a gente põe uns torresminhos assim por cima e cheiro verde, isso também vende muito, o tal do feijão amigo.

$\mathrm{P} / 1$ : Então acabou agradeço a senhora por fazer a entrevista.

R: Eu que agradeço, porque é muito bom a gente falar da gente, falar da nossa história, falar da nossa cultura, é muito bom isso. Então eu tenho muito o que agradecer vocês também por essa oportunidade. Igual eu falei no início, que a gente tá tendo oportunidade de estar mostrando a nossas coisas realmente como elas são. Então toda oportunidade assim é importante a gente estar mostrando isso, porque é uma história de vida, é uma história de um povo, e acho que ela tem que ser contada realmente como ela é, porque as nossas histórias sempre foram contadas por outras pessoas. A gente viveu situações aí de pessoas brancas se pintarem de negros pra nos representar. A gente não precisa disso. Então a gente, quando tem essa oportunidade de estar falando, estar mostrando as nossas coisas, é tudo que a gente quer, porque a nossa história é uma história autêntica, linda, linda, linda, linda. O povo negro é um povo que acho que merece, nossos ancestrais merecem todo o respeito porque lutaram muito pra gente estar aqui hoje numa condição ainda não muito boa, mas mais ou menos. Então a gente tem muito o que agradecer a esses negros guerreiros que fizeram todo esse trabalho, principalmente as mulheres; a gente ainda hoje na história lembra muito dos homens, dos heróis negros, e a gente não lembra muito das mulheres, mas nós tivemos mulheres fortíssimas negras que tiveram lideranças durante a história. É que não se registrou isso muito. Então a gente fundou aqui até uma associação, Mariana Creoula, em Volta Redonda, que são estudantes da FERP, uma universidade que tem lá, e a gente tá levantando essas mulheres, pesquisando o nome dessas mulheres pra fazer um trabalho, porque elas existiram, existem ainda e a gente tem que botar isso pra fora, aí, mostrar essas caras. Gente, mas muito obrigada pela oportunidade. 


\section{Depoimento de Aurino Pereira de Souza Entrevistado por Cláudia Leonor e Thiago Majolo \\ Serra do Cipó - MG, 8 de julho de 2007 \\ Realização Museu da Pessoa \\ Transcrito por Écio Gonçalves da Rocha}

$\mathrm{P} / 1$ : Então, senhor Aurino, começando a nossa entrevista, eu vou pedir pro senhor falar de novo o seu nome completo e a data do seu nascimento.

R: Meu nome completo é Aurino Pereira de Souza. A data do meu nascimento é 28 de abril de 1945.

$\mathrm{P} / 1$ : Em que cidade que o senhor nasceu?

R: Em Lençóis.

$\mathrm{P} / 1$ : E o povoado?

R: O povoado Remanso.

$\mathrm{P} / 1$ : É pertinho?

R: É perto de Remanso.

$\mathrm{P} / 1$ : É?

R: É.

$\mathrm{P} / 1$ : E o nome dos seus pais, o quê que eles faziam?

R: O que eles faziam? O meu pai chamava Justino Pereira de Souza, minha mãe chamava Maria Madalena de Jesus. $\mathrm{O}$ que eles faziam era trabalhar na roça, pescar no rio, que lá passam dois rios onde nós moramos, no povoado de Remanso, passam dois rios, o Santo Antônio e o Utinga. Eles vêm de fora e perto do Remanso eles fazem o encontro, aí em Remanso eles passam os dois juntos, é Utinga e Santo Antônio. $\mathrm{O}$ meu pai viveu e a maioria dos moradores de lá vive da roça e da pescada no rio; vivem pescando, trabalhando na roça e pescando. Disso é que se vive lá e o meu pai me criou nesse ritmo e o povo de lá tudo vive assim.

$\mathrm{P} / 1$ : E plantava o quê, senhor Aurino? 
R: Plantava mandioca, milho e batata doce, aipim, que lá a gente conhece por aipim, mas nos outros lugares têm vários nomes do aipim: uns conhecem por macaxera, outros conhecem por aipim, outros já conhecem por outros nomes, que eu me esqueci.

\section{$\mathrm{P} / 1$ : Mandioca.}

R: Mandioca, pois é. Então, mas lá a gente conhece por aipim, lá é o aipim. Tem a mandioca e tem o aipim, e a mandioca é a que faz a farinha. Lá nós temos também uma casinha de farinha manual, nós fazemos a farinha lá mesmo. Lá mesmo a gente planta a roça, planta mandioca e faz a farinha.

\section{$\mathrm{P} / 1$ : Como é que faz a farinha na casa de farinha?}

R: Já ouviu falar roda de braço? São dois puxando a roda e uma mulher, ou mesmo um homem, cevando no bolinete; são três pessoas: dois puxando e um cevando a mandioca. Aí ceva a mandioca, aí ela vira uma massa, a gente prensa, bate na prensa. Aí, depois da prensa ela enxuga e vai peneirar. Depois de peneirada, aí vai para o forno, que é à lenha. Bota lenha no forno e a gente vai torrando a farinha com um tipo de rodo. Então ela torra e aí a farinha você faz do tipo que você quiser. Se quiser mais grossa um pouco faz mais grossa, se quer ela mais fina faz ela mais fina.

\section{$\mathrm{P} / 1$ : Como é que faz pra ser mais grossa ou mais fina?}

R: Mais grossa você tem que apertar um pouco o fogo pra ser mais quente no forno. Isso se chama embola, aí ela fica mais grossa. E quando você quer ela mais fina, aí você deixa o fogo bem baixo, aí você torra e ela fica fina. Na hora em que ela estiver cozida, aí agora você aperta o fogo pra ela poder torrar. Aí você faz ela fina. Quando você quer que ela fique grossa você aperta o fogo mais um pouco e aí ela engrossa.

\section{$\mathrm{P} / 1$ : E coloca algum tempero nela, sal, alguma coisa?}

R: Não, na farinha não. Se coloca tempero, sal, ou até doce, se querem, é no beiju. O beiju você faz do jeito que você quiser também, faz de massa misturada com a goma. Uns chamam de goma, outros chamam de tapioca, é tirada da própria mandioca. Quando você vai espremer ela pra botar na prensa, aí você já tira a tapioca, uns chamam de tapioca, outros chamam de goma. Aí, se você quiser o beiju misturado, aí você bota metade de tapioca e metade da massa. Aí mistura, se chama beiju misturado. E se você quiser só da goma você faz só a tapioca, sem a massa, aí você faz do jeito que você quiser. Se você quiser temperada você bota um pouco de sal, se você quiser com doce você bota doce. 
$\mathrm{P} / 1$ : É gostoso?

R: É, com doce é bom. Sempre a gente lá faz mais é com sal, porque com sal você deixa mais tempo. Com doce, se você deixa ele endurecer, fica meio duro, e com sal não, você faz torradinho, fica o tempo todo você usando.

$\mathrm{P} / 1$ : E, senhor Aurino, como é que era a infância do senhor? Quantos irmãos o senhor tinha, como que era a convivência em casa?

R: Irmão eu tinha cinco, eram três homens e duas mulheres. Hoje só temos três, duas mulheres e eu como homem, os dois homens já morreram.

$\mathrm{P} / 1$ : $\mathrm{E}$ as meninas tinham uma educação diferente dos meninos, coisas que tinham que fazer, que não podia fazer?

R: É, tinha sim. Naquela época os velhos eram muito diferentes de hoje, só ia aonde eles queriam. Os homens quando estavam no domínio deles também só iam aonde eles quisessem. Mas depois que desse, naquela época era 18 anos em diante, aí eles faziam o que eles quisessem. O dizer dos mais velhos era: "Fulano já está sobre si", aí ele faz o que ele quer, aí ele não vai fazer mais a mandado dos pais. Enquanto não estivesse naquele mandato, ele só ia onde os pais quisessem, né? Agora, hoje é diferente.

$\mathrm{P} / 1$ : Mas o senhor brincava lá, ia no rio pescava, nadava? $\mathrm{O}$ quê que o senhor fazia quando o senhor era criança?

R: Ah, eu fazia muita coisa. Eu brincava, trabalhava na roça. Quando era pequenininho, que não agüentava trabalhar na roça, aí eu brincava. Naquela época não usava aula, não tinha escola onde eu morava, era uma roça, não tinha escola, não tinha nada. Aí o que fazia enquanto não agüentava trabalhar na roça era vadiar, aprender alguma coisa que os velhos ensinavam, rezar um Pai Nosso. Era isso que eles faziam. E à noite os velhos tinham aquele modo de ensinar pra ir dormir: "Vai rezar pra dormir, meu filho".

\section{$\mathrm{P} / 1: \mathrm{O}$ quê que rezavam?}

R: Rezava um Bendito, qualquer uma reza, daquelas que eles gostavam, pra livrar do mal, das doenças e aí ia dormir. De manhã tinha que levantar, dar bênção aos pais pra poder sair pra algum canto ou ir vadiar. É assim que eu fui criado. As meninas também do mesmo jeito. A criação hoje eu acho muito diferente da minha. É que os meus filhos eu criei quase do meu ritmo, porque eu, como mãe deles, foi criado assim. Agora, já hoje, se fosse de eu criar novamente eu achava difícil. É difícil por- 
que a lei hoje é muito diferente da época da gente e eu acho muito difícil. Hoje eu crio um neto, em alguma parte eu sigo a lei de hoje, mas em outras eu não consigo seguir. Não consigo seguir porque eu fui criado com o maior respeito aos mais velhos. A coisa que o pai mais castigava a gente era pra não desrespeitar os mais velhos, não responder. Se os mais velhos diziam qualquer coisa a gente tinha que acalmar; se uma pessoa mais velha reclamasse, qualquer menino achava que estava reclamando para $o$ bem, pra livrar de alguma coisa. Hoje a educação é a escola é quem dá, e antigamente quem dava a educação eram os pais. Educação de saber viver com o povo. Não era na leitura não, que a gente não aprendeu a leitura. A educação que os pais davam era saber viver. Saber viver que eu falo é respeitar, ter respeito, que tinha muito respeito na minha época.

$\mathrm{P} / 1$ : Pelos mais velhos.

R: Pelos mais velhos, um grande respeito. A gente não podia responder aos mais velhos, não podia xingar de nome nenhum na vista dos mais velhos.

\section{$\mathrm{P} / 1$ : Tinha que tomar bênção?}

R:Tinha que tomar bênção, tinha que tomar bênção. Passou o mais velho que o outro de dez anos, às vezes tinha que dar bênção àquela pessoa. Era assim que foi a minha criação. Agora, hoje é muito diferente.

$\mathrm{P} / 1$ : Mas, e de brincadeira? O senhor brincava do quê?

$\mathrm{R}$ : Ah, naquela época as brincadeiras da gente também era diferente das de hoje, as brincadeiras que hoje o povo chama como cultura, né? A gente ia brincar de roda. Quando já estava grandinho, que já sabia conversar, já sabia cantar, a gente tinha: "Embora cantar roda".

$\mathrm{P} / 1$ : Que música que cantava de roda, o senhor lembra?

R: Alguma música a gente lembra ainda, outras a gente não lembra mais não. Mas algumas a gente lembra, porque outras a gente esquece por causa de outra realidade que a gente vive. A gente se envolve com outras coisas hoje em dia, como o que está acontecendo com a música. $\mathrm{O}$ povo manda a gente fazer isso, fazer aquilo, e aí a gente esquece daquelas coisas mais velhas em que a gente foi criado, a gente esquece dos lugares, mas alguma coisa a gente ainda lembra. Você fala o que é a roda?

P/1: É.

R: A roda é o que a gente canta pra dizer um verso. Não sabe o que é dizer um ver- 
so?

$\mathrm{P} / 1$ : Fala pra mim, pra gente gravar. $\mathrm{O}$ que é um verso?

R: Um verso pode ser como hoje no griô tem um tipo de dança: Boi Mariá. "Bebeu, bebeu, boi Mariá, meu chapéu caiu, meu amor apanhou". Então isso era justamente uma roda que a gente brincava antigamente. Quando a gente estava rapazinho, as mocinhas e os rapazinhos diziam o verso: "Fui na fonte beber água, boi de Mariá, não foi pra ela beber, boi de Mariá, foi pra ver as piabinhas, boi de Mariá, na veia d'água correr”. Isso aí é um verso. E tem mais, vários versos que a gente dizia, que a gente só lembra na hora que a gente está cantando, aí agora vêm as idéias da gente, aí a gente lembra dos versos. Os versos vêm no meio da cantoria.

$\mathrm{P} / 1$ : Mas, senhor Aurino, vocês iam no rio nadar, iam fazer traquinagem?

R: Ah, eu acho que lá onde eu moro, nasceu, já todo mundo sabe nadar, porque lá a gente sé anda em cima de canoa, umas canoinhas muito pequenininhas, barco e coisa e tal. Se não souber nadar está arriscado a perder a vida qualquer hora. Lá onde eu moro é igual às capital pro lado do trânsito, dos carros, o trânsito de lá é canoa.

$\mathrm{P} / 1$ : É?

R: É. Aqui, nos comércios, nas capitais, o freguês anda com muito cuidado por causa de carro, modo de acidente, modo da pista, e lá nada com muito cuidado. Tem que aprender a nadar porque senão se afoga.

$\mathrm{P} / 1$ : E como o senhor aprendeu a nadar, sozinho?

R: Ah, lá se aprende a nadar rapidinho. Lá, é sozinho, é mais os colegas, vamos para o rio tomar banho, porque lá a gente toma banho é no rio. Tomava banho no rio, porque agora que está tendo banheiro, essas coisas de tomar banho, mas antigamente não tinha. Lá banho era no rio. A gente ia tomar banho era de noite, era de manhã, era meio-dia, qualquer hora. Toda hora estava dentro do rio, que mora na beira do rio. E o rio lá não dá pra sair de a pé, é fundo direto. Você tem que andar de barco ou de canoa. E lá você tem que ensinar logo o menino a nadar, porque é perigoso ele sair sozinho e se afogar.

\section{$\mathrm{P} / 1$ : E o pessoal faz lá canoa?}

R: Fazia. Hoje em dia não faz porque não está tendo madeira pra fazer. Hoje em dia, além de não ter madeira, as leis proíbem eles de tirar madeira pra fazer canoa. Mas antigamente nós tudo fazia canoa. Era a canoa da gente pescar, pra sobreviver a gente 
mesmo que fazia.

$\mathrm{P} / 1$ : Conta pra gente como é que era, que madeira que é melhor, que época que colhe essa madeira, como é que faz a canoa.

R: Hoje em dia se faz de muitas madeiras, mas antigamente era madeira escolhida. Era o ipê, esse cedro d'água. O cedro d'água até hoje ainda faz porque ele é uma madeira assim que dá muito, e é na beira d'água. Tem de dois cedros: tem o da mata, que dá na mata, e o que dá na beira do rio. Então todos os dois são bons pra fazer canoa. Então tem uma madeira que chama cocão, que é muito bom pra fazer canoa. Mas naquela época a gente fazia as canoas dessas madeiras, mas hoje não está tendo mais. Além de não ter, as leis impedem a gente de cortar madeira pra fazer. Pra fazer tem que pedir permissão às leis pra poder fazer a canoa. Mas a gente mesmo faz a canoa. Agora, o barco é feito de tábua. Acho que tem barco grande que pega até seis pessoas, oito pessoas. Esse daí é feito fora. Agora que está tendo um rapaz que mora lá, que já está fazendo lá mesmo, mas sempre comprava fora. Mas hoje a gente já tem um rapaz que mora lá, é casado até com uma sobrinha minha, que hoje ele fabrica lá mesmo, no Remanso, barco de todo tamanho que você queira. Faz pequenininho pra pescaria, porque o de pescaria é um pequenininho. Os grandes é só pra carregar o pessoal pras cachoeiras.

$\mathrm{P} / 1$ : É de madeira também esses barcos?

R: É de madeira, mas só que é um tipo de tábua. E a canoa que a gente faz é cavado. Sabe, cavar?

\section{$\mathrm{P} / 1$ : Cavado no tronco?}

R: É. A gente tira o tronco, aquela parte de madeira, o tamanho que você quer, o comprimento que você queira, e agora você vai cavando. Tira aquela madeira, deixa daquela grossura que você queira, vai cavando e se faz a canoa. E o barco é feito de tábua. Eles compram na serraria as tábuas e fazem o barco. E a canoa é lá mesmo, é cavado. Tem um tipo de ferramenta que se chama enxadão e enxó. A gente cava em primeiro lugar o machado, segundo o enxó e enxadão, é que a gente faz a canoa.

\section{$\mathrm{P} / 1$ : Quanto tempo demorava pra se fazer uma canoa?}

R: Pra fazer uma canoa é conforme o tamanho e a largura. Quando é uma pescaria lá que pega só duas pessoas, se faz em cinco dias. Pra fazer bem feita uma pessoa faz em cinco dias uma canoa que pega duas pessoas. Agora, grande, aí demora. Quanto mais cresce no tamanho, mais cresce nos dias de fazer. Faz em uma semana, faz em uma semana e meia, faz em duas semanas. Aí depende do tamanho da canoa. 


\section{$\mathrm{P} / 1$ : E com quem o senhor aprendeu a fazer canoa?}

R: Aprendi com os meus tios, meus pais, eles tudo faziam canoa. Eu já aprendi logo, porque os velhos, antes que eles morressem, eles já passavam tudo que eles sabiam pros filhos. Nem tudo também, algumas coisas; porque os velhos tinham segredo do que sabiam também. Aqueles filhos que eles mais interessavam, eles passavam tudo que eles sabiam. Aqueles que eles nem interessavam, aí eles negavam alguma coisa. Faziam que nem o gato mais a onça, ensinavam os furos mas o principal não ensinavam não.

$\mathrm{P} / 1$ : Mas que tipo de segredo será que eles tinham?

R: Alguma oração de ciência que eles tinham, e não ensinavam os filhos não. Tinha algum filho que eles podiam ensinar aquelas orações de reserva deles, de garantia, de livrança. Não eram todos os filhos que eles tinham coragem de ensinar. "Não, isso daqui você não pode aprender não, você está muito novo". E aí ficava naquela e o cara ficava velho e ele não ensinava. E aí era assim. Eu gostei muito de meus pais. Eu era muito apegado com o meu pai, tanto que quando ele morreu eu levei muito tempo apaixonado pelo velho. Gostava muito do meu pai. Não sei por que, os outros irmãos têm até ciúme porque eu era o caçula. Ele me queria muito bem, em todo lugar que ele ia ele me levava. Os outros tinham ciúme: "Parece que o pai gosta mais de você do que da gente", "Não mano, é não, é porque é o caçula". Eu sou mais novo que o meu irmão cinco anos. Acho que ele não esperava mais que ia aparecer eu, e aí ficou com esse ciúme até hoje. E eu senti muito a falta do velho. E tenho muita também da minha mãe, mas a minha mãe demorou mais, ela morreu muito mais derradeira e ele foi primeiro.

$\mathrm{P} / 1$ : E tinha festas religiosas, procissões que vocês acompanhavam?

R: Tinha e ainda tem.

$\mathrm{P} / 1$ : Que procissão que é?

R: Procissão de São Francisco. O padroeiro lá do lugar da gente, São Francisco das Chagas. Porque diz que tem dois São Francisco. Tem um que é de Assis e outro que é das Chagas. Diz o povo, mas acho que é um sozinho.

P/1: Que época que é a procissão, como que é?

R: No dia 4 de outubro que é a festa de São Francisco e tem a procissão. Agora, a festa mesmo começa no dia 25 de setembro. Tem as novenas e todo dia tem reza, tem 
festa. Aqueles novenários é quem fazem a festa. Às vezes são duas pessoas ou três: "Essa noite é de fulano", por exemplo, "é de fulano e cicrano e beltrano". Aí você faz a festa. Se a noite for sua, você faz a festa do jeito que você quiser. Se você quiser fazer forró, você faz, se tem uma banda pra tocar, você leva. Isso aí é problema seu, a noite é sua, você faz do jeito que você quer. Ali rezou, você faz a noite. Se você não quiser fazer nada você também não faz, só faz a reza e solta um foguete, acende uma vela, o pessoal reza. Você querendo: "Vou fazer uma festa no dia da minha noite", aí você faz a festa do jeito que você quiser. Do dia 25 até no dia 4 de outubro. Dia 4 que é do santo, é do padroeiro da gente.

\section{$\mathrm{P} / 1$ : Aí tem o quê? Tem missa? O que tem dia quatro?}

R: Tem missa, tem batizado, tem até casamento, dependendo. Hoje em dia não está tendo mais, mas antigamente tinha muito casamento, todo ano da festa tinha casamento. Tem batizado, um monte de batizado. Esse ano mesmo teve muito batizado. $\mathrm{O}$ padre vai lá, batiza muitos meninos pagão.

$\mathrm{P} / 1$ : E tem esse negócio de quermesse, de ter barraquinha de doce, salgado?

R:Tinha, tinha muita quermesse. Hoje em dia quermesse não está tendo quase mais, mas barraca pra vender coisa tem, tem muita barraca.

$\mathrm{P} / 1$ : O que vendia quando você era criança?

R: Naquela época vendia muito, hoje vende também, mas naquela época vendia mais coisa porque o pessoal levava mais coisa, demorava mais. Vendia várias coisas, tira-gosto, o que vende sempre em barraca. Era tira-gosto, era pinga, era vinho, era cerveja. Vende de tudo lá na barraca, tira-gosto, peixe frito. Hoje lá até está tendo um peixe que o povo é muito chegado a ele, é um que chama molé. Conhece? É um peixinho pequeno, ele é de couro. Aí eles até fazem o caldo. Eles cozinham ele, tiram a carne, só a carne, que ele não tem espinho não, só tem o espinhaço. $\mathrm{O}$ corpo dele tudo é carne. Aí eles cozinham, tiram a carne, batem no liquidificador e faz o caldo. Aí o pessoal não deixa ele esquentar, porque é muito forte. É o peixe do rio que é mais forte, o povo dá muito de valor. Porque diz que os velhos, naquele tempo, os que tinham muitos meninos era por que comia esse peixe.

\section{$\mathrm{P} / 1$ : Uma receita forte?}

R: Ficava muito forte, aí diz que tinha muito menino, os velhos. Tem velho lá que teve acho que vinte e tantos filhos; o casal, teve vinte e tantos filhos lá, os mais velhos. Acho que dos casais lá, do meu tempo pra cá, que tem mais pouco filho foi o meu pai mais a minha mãe, mas os outros tudo se fala de dez, doze, quinze, vinte em diante. 
$\mathrm{P} / 1$ : Senhor Aurino, quando aprendeu a tocar sanfona? Quando e quem te ensinou.

R: Hoje eu dou como o meu mestre o meu pai. Porque ele não me ensinou assim próprio: "Vem cá, meu filho, deixa eu lhe ensinar". Mas eu dou ele como meu mestre, pra mim foi ele quem me ensinou porque ele que tinha o instrumento. Eu olhava pra ele fazer o trabalho. E aí tive aquela inteligência de prestar atenção. $E$ aí ia lá e pegava sem a explicação dele, e eu fui indo e aprendi. Aprendi assim, quase escondido dele, porque ele não queria que eu pegasse no instrumento. Mas o ciúme dele era o medo de perder o instrumento. Perder assim: porque naquela época era muito difícil pra se encontrar esse instrumento, qualquer instrumento. $\mathrm{O}$ instrumento mais fácil, naquela época, justamente era uma viola, era um violão, porque tinha gente por perto que sabia até fazer de madeira, gente que no meio da parentalha mesmo sabia fazer uma viola, sabia fazer um violão de madeira. Mas uma sanfona ninguém sabia fazer. Então, nem sabia fazer e nem tinha quem, se quebrasse, consertar, que era difícil.

$\mathrm{P} / 1$ : Tinha que mandar pra onde, pra Salvador?

R: Tinha que mandar pra longe, mandar pra Itaberaba, pra outro lugar longe. E naquela época o pessoal da roça não sabia nem andar. Só sabia andar da roça pra cidade, pra ir pra feira. Pra sair pra outro lugar ninguém sabia andar. Então era difícil, ninguém conhecia ninguém. Era difícil, então ficava com ele. Era o divertimento do povo da região.

$\mathrm{P} / 1$ : Ele tocava e cantava também?

R: Ele tocava, ele cantava. Ele cantava reisado.

$\mathrm{P} / 1$ : O que é cantar reisado?

R: É Reis que sai no dia primeiro de janeiro, é o reisado, Santo Reis.

$\mathrm{P} / 1$ : $\mathrm{E}$ vai parando nas casas?

R: É verdade. Ia parando nas casas. E saía, passava oito dias fora, nas casas, pra cantar. Lá era a minha tia, que era a irmã de meu pai, é que era dona do terno, chamado. Era ela quem tinha o santo, Santo Reis. Aí ela saía todo ano com o terno de Reis, e o meu pai que era o cantador, ele é que sabia cantar o Reis. Depois que ele morreu ficou pro filho dela mesmo, que é esse que foi o fundador da associação nossa lá, que chama Manoelzinho. Ele já morreu.

$\mathrm{P} / 1$ : Senhor Aurino, o senhor trabalhou? No que o senhor trabalhou? 
$\mathrm{R}:$ De roça ou de outra coisa?

$\mathrm{P} / 1$ : Qualquer coisa. Qual foi o primeiro trabalho do senhor?

$\mathrm{R}$ : Ah, o meu trabalho sempre é isso mesmo, é roça. Que naquele tempo tinha muito aquilo que a gente fazia na roça, pescaria e fazer festa. Fazia festa, que hoje eu não aprendi várias coisas por causa da minha vaidade, a idade, e achava que aquilo não valia de nada. E hoje eu estou arrependido porque não aprendi as coisas do meu pai, dos meus tios, dos meus primos, que sabiam várias coisas de cultura. Sabia reisado, formava reunião, fazia festa de índio. Fazia marujada, não sei se você conhece.

$\mathrm{P} / 1$ : $\mathrm{O}$ que é marujada?

$\mathrm{P} / 1$ : Marujada é um cordão de grupo, a mesma coisa que a gente faz numa roda, numa festa, a gente faz a marujada. Marujada tem o piloto, tem o mestre e tem o cordão, que a gente dança. Tem as palavras que a gente fala da marujada e tem as músicas. Aí é um cordão de marujada. Em Lençóis mesmo tinha. Ainda tem ainda, mas está devagar, que os chefes, os velhos, morreu tudo. O Omar Siciliano, que era o chefe da marujada de Lençóis, esse morreu. Depois ainda ficou o filho dele, também tomou conta, mas o filho também morreu esses tempos, chamava João. E aí a marujada está um pouco devagar. Ainda tem lá, mas só sai de ano em ano, na festa do padroeiro. O padroeiro de Lençóis é o Senhor Bom Jesus dos Passos, é no dia 2 de fevereiro. Essa marujada era de lá. Isso também a gente levou pro Remanso e a gente foi vendo uma brincadeira também. E tinha o nosso grupo de marujada também, mas isso hoje se acabou também porque o jovem de hoje não gosta muito dessas coisas, não está querendo. Vai fazer o quê? Os mais velhos se acabou, aí por isso que foi por água abaixo.

$\mathrm{P} / 1$ : Mas o senhor sabe dançar, aprendeu a dançar marujada?

R: A marujada ainda sei, ainda lembro ainda dançar. Se for pra dançar ainda danço.

$\mathrm{P} / 1$ : E que papel que o senhor fazia?

$\mathrm{R}$ : Na marujada a primeira coisa que eu fui foi ração, se chama o termo ração. Era menino, lançou um grito, o mestre chama, o piloto chama, o ração responde. Ele chama: "Oh, ração!", a gente diz: "Oh, mestre”. Vai lá, torna a voltar e ele fala aquelas palavras. E aí agora eles chamam os marinheiros e aí fala as palavras, manda puxar as músicas. Agora todo mundo vai dançar. Eu aprendi a dançar com eles me botando como ração. E daí, de ração eu subi, fui pra posição de piloto. O meu irmão era o mestre, era o mais velho. E aí ele morreu, a gente formou o cordão. Eu fiquei como 
mestre e outro rapaz que tem lá ficou como piloto, mas só que não foi à frente porque saíram, um disse que não queria mais, que ia trabalhar fora, outro saiu. E é coisa que não se pode fazer com dois mais três, pode fazer um cordão com mais de dez pessoas em diante. Aí foi indo, acabamos. A gente tem três fardas lá.

$\mathrm{P} / 1$ : Tá guardado?

R: É. Pra sair assim tem que sair fardado.

$\mathrm{P} / 1$ : É branco?

R: Pode ser branco e azul, e pode ser também outra cor, qualquer cor, aí dependendo da combinação do cordão do grupo. Nós queremos de tal cor, assim, assim, aí é tudo de uma cor só. Aí a gente combina e manda fazer a farda. A gente tem uma lá. A da gente é toda branca e agora tem uns vivo azul. Temos lá a farda ainda que foi doada pra gente, mas só que o cordão parou porque o pessoal saiu, outros saíram, outros disseram que iam trabalhar fora, outros mudaram de lá. Aí parou o cordão. E eles hoje, a vida é me cobrar esse cordão de marujada. A vida lá da região lá, do pessoal, é me cobrando, me cobrando, me cobrando, mas eu não posso fazer nada, que eu não posso fazer sozinho, né?

$\mathrm{P} / 1$ : É difícil ensinar?

R: Não, não é muito difícil não. Pra ensinar é fácil, dependendo de que as pessoas queiram não é difícil não. É fácil pra ensinar.

$\mathrm{P} / 1$ : E a marujada com quem o senhor aprendeu?

R: A marujada eu aprendi com o meu primo. No tempo do meu pai eles não sambavam marujada não. Mas aí já foi com o meu primo, com esse que eu falo que é o chefe, que foi o fundador da associação lá. Ele foi o fundador até da população do lugar, porque juntou o pessoal que morava distante assim um do outro. E ele veio, fez um povoado. Onde a gente mora tem um povoadozinho. Nessa época não tinha energia, hoje já tem energia, tudo puxado. Foi ele quem puxou. Hoje tem escola, tem prédio de escola. Tem posto, só que o posto não está funcionando porque não tem coisa pra funcionar. Não tem médico nem enfermeiro, mas o posto está lá feito. Tem o posto e tem o prédio de escola.

$\mathrm{P} / 1$ : Quando e quem te convidou o senhor foi convidado pra ser mestre griô?

R: Quem me convidou foi o professor Márcio, foi ele que me convidou, ele que me chamou pra fazer parte da trilha dos griô. 


\section{P/1: O senhor já conhecia o Márcio?}

R: Não, eu não conhecia o Márcio. Nessa época eu não conhecia ele, depois ele andou por lá, coisa e tal, sondando. Acho que ele percebeu pelos forró da gente, que a gente fazia forró, e até hoje a gente faz forró por aqueles lugares tudo ali, tem em Lençóis, Andaraí, aquela redondeza tudo o povo chama e a gente vai fazer o forró. E aí eu acho que ele observou de um forró e encostou por lá, esteve por lá. E sempre eles gostam também de visitar a escola, o grupo deles sempre visita a escola. E esteve por lá e me chamou: "Vamos ali fazer uma caminhada ali mais o velho griô". A primeira vez que ele esteve lá em casa se vestiu lá de griô e: "Vamos fazer ali uma caminhada, bater ali um bumbo". Tocamos uma viola e eu fui bater bumbo. Aí, daí pra cá começamos.

\section{$\mathrm{P} / 1$ : Já na caminhada mesmo?}

R: Já na caminhada. Me chamou, me convidou pra fazer uma caminhada. Foi lá mesmo, lá no povoado. Ele foi lá visitar as escolas e aí me chamou pra fazer essa caminhada: "Vamos ali mais eu bater um bumbo, vamos acompanhar o velho griô??" Eu digo: "Vamos embora". E aí foi quando a gente, nessa caminhada, aí começamos. Ele me convidou e aí eu vim, sempre eu venho e até hoje estou. Gosto muito e estou muito me dando bem com eles.

$\mathrm{P} / 1$ : E aí o senhor tinha noção assim do quê que era um velho griô?

R: Ah, eu não sabia. Até aí eu estava lutando e ele não me falava que era um griô, mas não falava o que era o griô. Um dia ele fez as procuras, se eu sabia o que era o griô, me explicou. Eu acho que eu tenho isso gravado. Eu digo: "Nossa, eu mesmo não estou bem por dentro como é o griô não". E ele: "Não, mas pra você, o que você pensa assim mais ou menos o que é?". Eu digo: "Bom, pra mim o griô é uma coisa que vai trazer as coisas velhas, que pelo jeito do griô eu acho que ele vai, é esse tipo de coisa que vai trazer aquela lembrança dos velhos pais da gente, dos tios, desse povo, aquela lembrança". Pra mim o griô é desse tipo, porque eu nem sabia o que era griô. Porque pelo que eu vi o griô fazer, dá a aparência daquelas coisas antigas, dos velhos. Dá aquela aparência daquela coisa dos velhos, aquela dança, era cantar roda, era dizer verso, fazer essas coisas pra mim é o que é o griô, é lembrar, é trazer. O griô tá vindo pra trazer a lembrança dos velhos, que acabou.

$\mathrm{P} / 1$ : E como que o senhor conhece a ida dos griôs nas escolas tradicionais, que é o saber oral e tudo, pras escolas? O senhor tem ido nas escolas?

R: É, eu tenho ido com eles nas escolas. 
$\mathrm{P} / 1$ : Qual que é a diferença?

R: Sempre eu luto lá com eles, sempre, eles me chamam pra brincar lá junto com eles. Eu me dou muito bem também com o grupo dele, que ele tem um grupo dos meninos que tocam e eu toco junto com eles. De vez em quando a gente vai lá dar uns ensaios. Época de São João a gente quem toca pra São João e é junto com os meninos. Os meninos é com guitarra, é com baixo, eles já têm os instrumentos todos.

P/1: São João é das festas mais importantes da Bahia.

R: Em Lençóis, ali naquela redondezinha, é o mais que adora a festa de São João, porque não é fácil não. Tem anos que eles começam do dia 21 , só vai acabar lá perto de São Pedro. Outra hora emenda com São Pedro.

$\mathrm{P} / 1$ : E porque é São João?

R: Porque que eles gostam assim? Porque, você acha...

$\mathrm{P} / 1$ : Porque eles gostam?

R: Eu acho que, sei lá, não sei se é por causa do santo mesmo que trás aquela energia pro povo. São Pedro nem tanto, São Pedro é meio devagar, mas o São João lá quando o povo não faz festa o povo fica cobrando: "Esse ano São João não prestou não, não teve festa que presta, não teve isso, não teve aquilo". O povo cobra logo. Quando a festa de São João não está boa o povo cobra logo, fica logo cobrando, só falando, falando, falando. E vem muita gente de fora também. Não sei por que Lençóis tem essa energia assim que chama o povo mesmo, muita gente de fora no São João. Muita gente vai passar o São João em Lençóis.

$\mathrm{P} / 1$ : Quem que é o aprendiz que está com o senhor?

R: Por enquanto é dois meninos lá do Grãos.

P/1: Quem que é?

R: Moça, você sabe que tem um que eu tô lembrado do nome mas o outro eu não. Vou procurar a menina ali porque eu esqueço do nome dos meninos.

$\mathrm{P} / 1$ : Não tem problema. Mas o quê que o senhor ensina pra eles?

R: Tocar sanfona. E junto com eles lá no griô, tem hora que a gente canta umas músicas, lembra de umas músicas, daquelas músicas velhas. Aí eu passo pra eles. Mas 
eles estão mais interessados que ensine a tocar. Quer dizer, o pessoal do griô está mais interessado que eu ensine os meninos a tocar sanfona, ali na região só tem eu e acho que eles estão com medo de eu morrer, aí acabar e ninguém não aprender mais a tocar sanfona e ficar sem tocador. Aí então a gente já tem um garotinho, é até parente da gente lá, mora em Lençóis, que botou pra cantar comigo. É inteligente que é danado. Já tem parece que umas oito músicas dele, que ele já fez lá, está tocando.

\section{$\mathrm{P} / 1$ : É difícil tocar sanfona?}

R: Não, eu acho que não é difícil, dependendo da vontade da pessoa. Se a pessoa tem vontade, gostou, eu acho que não é difícil. Que nem esse menino mesmo, eu acho que foi umas duas ou três vezes que eu expliquei pra ele e ele já está bem adiantado. E já o outro não, o outro é mais devagar. A gente explicou aquilo ali, ele não tira da cabeça e vai caçando até encontrar. A pessoa, como eu digo, se tiver vontade eu acho que não fica difícil. Tudo que a gente tem vontade a gente vai fazer e Deus ajuda. E eu acho que Deus ajuda, que a vontade ali, eu acho que Deus ajuda que não dá trabalho pra pessoa conseguir.

$\mathrm{P} / 1$ : O senhor, pra aprender, se inspirou no seu pai, né?

R: É.

$\mathrm{P} / 1$ : Quem te ensinou mesmo?

R: Não, provavelmente vamos dizer que quem me ensinou mesmo foi assim o tempo. Foi o tempo mesmo porque o meu pai veio me dar alguma explicação depois que ele viu que eu já estava adiantando alguma coisa. Quando ele descobriu eu já estava adiantando alguma coisa. Eu estava aprendendo escondido. Então, quando ele viu eu já tinha adiantado alguma coisa. Aí ele liberou. Desse dia pra cá liberou, me deu alguma explicação e parou aí. Eu aprendi mais com o tempo. Chegava numa festa, sempre era festa direto. A gente saía pra fora, encontrava com outros tocadores por lá por fora. Aí eu chegava na beira, ficava na beira. Toda vida eu, inteligente, gostava muito de bater um instrumento. Batia um pandeiro, batia um triângulo. Tinha um instrumento que se chama maracaxá, que rapa assim: "Choc, choc, choc, choc". Aí eu ia fazer esse trabalho pra eles lá na festa, era garoto e tinha as horas ali, porque naquela época: "Menino não pode ficar até tarde", tem aquela hora, não pode dormir tarde. E assuntando o movimento deles, como eles faziam. Aí eu ficava naquele instrumento ali assuntando, assuntando. Quando passava daí, que eles paravam a festa, aí eu ia lá experimentar o que eles estavam fazendo. Foi assim, dessa forma. Eles puxavam ela assim, eu via eles batendo quando dava desse jeito.

$\mathrm{P} / 2$ : Qual é a sanfona que o senhor toca? 
R: Oito baixo. Essa é bem mais pequena e ela é meio complicada. Sanfona eu acho que é essa que eu tenho, que é mais pequena. Essas grandes, que chamam paleta, se chama hoje de acordeom. É dessas grandes, esse dente branco, aquele teclado branco. Aquela dali eu acho que é mais fácil porque é um som só. Se você quer um sol, você puxa ela pra lá, puxa ela pra cá, é o sol. Se você quer um dó, você puxa ela pra lá, puxa ela pra cá, é um dó. E a oito baixo não é. Você puxa pra lá, é um dó. Você puxa, quando você vem é um sol. Ela é complicada por causa disso. É porque, na hora que você puxa aqui é um tom, na hora que você vai voltar já é outro tom. E a paleta não, você puxa e volta, é um som só. Se você estiver em dó é um dó só. E a oito baixo não, se você for pra lá é um sol, quando você vem já é um dó. Ela é complicada mais por isso, você tem que saber manejar ali pra modo de você traduzir de um para o outro, pra ficar um por um. Você tem que saber traduzir no fole e na saída, entendeu, pra modo de ficar um por um, porque pra ser um dó direto você tem que ir pra lá. Aí você sai do lugar, muda a mão de lugar, o baixo também, pra quando você vir já ser o mesmo dó. Você tem que mudar. Por exemplo, aqui é dó, você vai puxar pra lá. Aí você tem que mudar, e mudou o de cá também, pra modo de quando vir já é o mesmo dó, porque se você deixar no mesmo lugar já é outro, entendeu? E a paleta não, você pode ficar no mesmo lugar que você vai e vem, é um só. Quando você muda, você muda pra fazer outro relativo do tom, você muda pra você fazer relativo. E a oito baixo não, você tem que mudar pra ser o mesmo tom. É por isso que eu acho que seja mais complicado. Dizem eles que é mais complicado, e pelo jeito eu acho que é mesmo porque os meninos desandam mais na paleta do que na oito baixo.

P/1: E Senhor Aurino no mundo de hoje, com tanta coisa, tanta informática, qual a importância de o senhor estar ensinando outras pessoas a tocar sanfona? Como é que o senhor vê o trabalho do senhor agora?

$\mathrm{R}$ : Eu me interesso muito porque eu tenho o maior prazer, se por acaso eu morrer, de deixar quando nada uns dez ou vinte aprendizes, pra quando nada ficar a minha lembrança, que eu tenho lembrança com o povo. Às vezes, quem sabe, que eles estão falando depois a mesma coisa que eu estou falando aqui, não é verdade? A mesma entrevista que você está entrevistando aqui, pode entrevistar qualquer um dos meus aprendizes. Amanhã ou depois: "Quem me ensinou foi um velho que chamava Aurino, por essa forma e essa". E é o desejo que eu tenho, de deixar. Isso era pra deixar pros meus filhos, mas os meus filhos não interessam nada.

$\mathrm{P} / 1$ : Mas tocam algum instrumento, não?

R: Uns tocam alguma besteirinha. Tocar instrumento assim, bater um bumbo, outro triângulo assim, mas sanfona mesmo não. Um lá que diz que tem vontade de tocar é bateria, esses negócios, violão, essas coisas, mas sanfona não tem. 
$\mathrm{P} / 1$ : É o rock que eles preferem?

R: É, eles são mais chegados a som, esse tipo de coisa, a escutar, não fazer. Eles são mais chegados a escutar, não a fazer. No meu tempo os meus irmãos todos aprenderam alguma coisa de cultura. $\mathrm{O}$ meu irmão mais velho era tocador de pife, que nem o menino aí, o seu Zé. E era da região, o melhor da região que era. Ele era de Salvador. Tem muito tempo que ele morreu não. Era bom nesse pife aí, era bom mesmo. E o outro tocava um pouco de sanfona também, o outro, o da beira, mais novo.

$\mathrm{P} / 1$ : Senhor Aurino, como é que foi assim o convite pro senhor ser um mestre griô?

R: Esse convite foi justamente como eu acabei de lhe dizer, ele descobriu pela festa, pela farra que a gente fazia.

\section{$\mathrm{P} / 1$ : Depois de algumas caminhadas?}

R: É, depois dessas caminhadas eles me chamaram lá e me convidaram pra ser o mestre lá do griô, e o moço: "Você é, você agora vai lutar com a gente, é um mestre do griô".

$\mathrm{P} / 1$ : E esse trabalho que a gente está fazendo aqui, da Ação Griô, o quê que é importante, o quê que significa pro senhor estar aqui com outros mestres, qual é a importância?

R: Ah, pra mim é muita importância, que pra mim a importância é pra mim conhecer o povo. E eu tenho o prazer de fazer o trabalho junto com o povo, ter mais amizade. Cada dia passa, as amizades crescem mais. Mais conhecimento, cada dia passa, mais a gente conhece o povo. Mais conhece os lugares. Um desejo que eu realizei, um sonho que eu realizei agora também, que eu tinha vontade de andar de avião.

$\mathrm{P} / 1$ : Ah, foi a primeira vez?

R: Não, eu tinha esse desejo, mas agora parece que é a quarta vez. Porque a gente foi pra São Paulo de avião. E fomos pra Espanha.

$\mathrm{P} / 1$ : Ah, o senhor foi pra Espanha?

R: Fui com eles pra Espanha, fomos de avião.

$\mathrm{P} / 1$ : Se apresentar lá com a sua viola? 
R: Foi com a sanfona.

P/1: E qual que foi a emoção? Uma viagem longa...

R: Longa.

$\mathrm{P} / 1$ : E chegar em outro país. Como é que foi isso pro senhor?

R: Ah, lá foi muito ótimo, lá foi muito bom. E tem mais, o companheiro lá, o grupo lá foi muito legal. Essa viagem da gente saiu o convite de um encontro em Guarujá, que foi convidado pra ir a um festival do griô, aí a gente foi de ônibus pra Guarujá. Passamos em Guarujá quase uns 18 dias.

$\mathrm{P} / 1$ : Fazendo o encontro?

R: É, fazendo o encontro. A gente apresentava nas escolas, apresentação nas escolas. Passamos a semana toda apresentando nas escolas. Tinha vez que eram duas apresentações por dia, uma dez horas e outra acho que era três horas.

$\mathrm{P} / 1$ : E aí, nesse encontro que veio o convite?

R: Aí foram seis grupos, cada país um grupo. O grupo daqui do Brasil foi a gente. E veio da Espanha, veio o povo do Equador, de um bocado de lugar aí, de país. Aí foram seis grupos, com o da gente, e a gente ligado com o da Espanha. Aí foi aquele amizadão danado, a gente aprendendo a dança deles, eles aprendendo a dança dos meninos. Estava um grupo grande, que tinha 20 e tantas pessoas. E aí formaram aquela amizade, e aí acho que foi um deles que me convidou, o professor Márcio aí, o chefe, pra ir lá. Aí passaram uns dois anos, aí eles presentearam e a gente foi. E aí esse grupo está vindo agora também aqui, fazer uma visita em Lençóis.

P/1: Senhor Aurino, qual a sensação de estar em outro país, conhecer outra língua?

R: É justamente isso que estou lhe falando. A emoção que me dá, nesse programa de eu estar no griô, é o que eu estou lhe falando: é esse sonho que eu tinha de andar no avião. E eu nem pensava de conhecer nem São Paulo. Hoje já outros lugares eu estou conhecendo. Conheço o Rio de Janeiro, conheço São Paulo, já estou conhecendo aqui Minas.

\section{P/1: O senhor não conhecia Minas Gerais?}

R: Não, Minas eu nunca tinha visto não. Eu nunca tinha vindo aqui em Minas. E está arriscado de conhecer mais outros lugares, e estou querendo ver se eu conheço, viu? 
Então o meu prazer, nessa situação, é esse, é ter o pessoal. Porque a minha natureza, a minha vontade é igual à música de Roberto Carlos, que a gente tem que ter um milhão de amigos pra poder viver mais forte. É que nem a música de Roberto Carlos. Ele tem essa música: "Eu quero ter um milhão de amigos, viver mais forte pra poder cantar". Então, é esse o meu desejo. Quanto mais eu tenho amizade, quanto mais eu tenho amigos, pra mim é igual o dinheiro. Tem gente que quanto mais tem dinheiro mais acha que é pouco. É igual a eu com amizade, quanto mais eu tenho amizade mais pra mim eu quero ter mais. Pra mim, a minha felicidade, a minha riqueza é os amigos, as amizades que eu faço. Sou tanto chegado à amizade e pessoal que no meu lugar eu não tenho diferença com ninguém, acredita? Eu acho que a minha sorte, que Deus me deu, não tenho diferença pra lá, no meu lugar ou Lençóis. Lá no meu lugarzinho, no meu povoado todo mundo é assim. Daí a meninada toda me chama: "Velho Aurino pra aqui, velho Aurino pra acolá". Todo mundo me respeita, todo mundo gosta de mim. Eu acho, eu sinto que gosta. Não sei se é verdade, mas pelo jeito que me tratam eu acho que gostam. Lençóis é a mesma coisa. Quando eu chego em Lençóis, é pra arriba, é pra baixo, é rico, é pobre, é menino, é gente velha, é tudo assim mesmo, me abraçam. Eu tenho o maior prazer de viver no meio do povo. Pra mim, a riqueza que eu tenho é o povo, é a amizade do povo. Pra mim não tem coisa melhor do que certas amizades. É como na situação que eu estou lhe dizendo, que eu tenho de estar aqui hoje, junto com vocês aqui, proseando aqui com você. É essa situação que eu tenho, e tenho o desejo de ser hoje, amanhã, depois e toda hora, e todo dia enquanto vida eu tiver.

\section{P/1: Senhor Aurino, a Eniele é aprendiz do senhor?}

R: É, a Eniele aprende. Ela aprende muito lá no griô com outros mestres também. Que tem a Rosa, que é parente minha, minha prima, tem a Lina, que é tudo lá do griô, é mestre lá do griô. E ela aprende nesse gregário com a gente tudo. Cada qual ela aprende uma coisinha.

\section{$\mathrm{P} / 1$ : Com outros griôs ela aprende?}

R: É, aprende. E ela puxa um galhinho de cada um e aí vai seguindo. De cada um ela tira um galhinho, uma folhinha, e vai seguindo.

\section{$\mathrm{P} / 1$ : Ela tem talento pra sanfona?}

R: Rapaz, eu ainda não vi ela dando um jeito assim pra ter. Talvez pode até ter. Mas eu não sei se é por causa dos outros trabalhos que ela faz, que ainda não deu tempo de ela estar chegando na sanfona pra dizer assim: "Eu quero mesmo". A não ser que eu não sei. Porque eu só venho no griô assim uma vez na semana ou tem vez que passa uma semana sem vir, que eu moro mais na roça. Eu fico mais na roça, porque os 
meus filhos é quem fica em Lençóis. Tem um barracozinho, eles ficam lá em Lençóis, mas eu gosto de ficar mais lá na roça. Eu e minha mulher, porque eu já acostumei na roça, a trabalhar. Eu arranjo o meu trabalhozinho, arranjo a minha pescadinha, e aí eu fico por lá, e o meu pessoal, os meus filhos moram tudo cá em Lençóis. Eu fico lá, eu e a mulher. Só venho final de semana pra rua, pra cidade. Eu venho final de semana, que a gente vem pra cidade, mas a semana eu passo lá na roça, em Remanso. É um povoadozinho mas tudo é roça. Cada qual tem a sua roça lá, tem a sua canoa, tem coisa de pescar. É assim que a gente vive lá. $\mathrm{E}$ os filhos é que ficam na cidade. Eu não gosto de ficar na cidade porque eu não acho trabalho pra trabalhar.

$\mathrm{P} / 1$ : E como o senhor se sente sendo um mestre griô?

$\mathrm{R}$ : Ah, eu me sinto muito prazeirado, eu me sinto muito satisfeito, que eu não esperava de ser, nem pensava de ser mestre. Pra mim o mestre era uma coisa que eu nunca ia chegar lá, nesse lugar de mestre, porque mestre pra mim é uma grande coisa. E hoje eu me sinto muito prazeirado, muito satisfeito. O que precisarem de mim nessa parte, precisarem de alguma coisa, eu estou pronto. $\mathrm{O}$ que eu puder fazer, até disponho.

$\mathrm{P} / 2$ : Enquanto o senhor trabalhava na roça, em algum lugar, sempre quando tinha um tempo pegava a sanfona? Como é que era?

R: Moço, tinha vez que eu tinha tempo assim uma vez na semana, final de semana, no domingo, sábado. Todo final de semana eu pegava porque lá todo final de semana tinha festa, fazia festa, tinha reunião. A gente ia se reunir, que a gente tinha uma comunidadezinha lá, uma associaçãozinha lá, dos pescadores. E aí todo sábado a gente tinha que se reunir pra acertar alguma coisa, falar do trabalho. Aí, nessa reunião, a gente se reunia sempre à noite, sempre era de seis, sete horas da noite. Sempre eram três horas de reunião. E aí acabava de fechar com a festa, com forró. Todo final de semana a gente acabava a reunião, fazia o forró. Aí comemorava, bebia por ali uma cervejinha, uma coisa e fazia forró. Mas todo final de semana tocava sanfona. Agora hoje tem vez que passa uma semana, não pega na sanfona. Hoje tem um monte de instrumento. Antigamente não tinha música pra gente escutar. Tinha que chegar, pegar a sanfona e fazer uma música. Hoje tem muita música. Quando dá a noite a gente chega, descansa um pouquinho, toma um banho, descansa um pouquinho, ao invés de pegar na sanfona: "Eu vou assistir televisão", assisti isso, assisti um filme. Às vezes o menino está lá: "Eu quero assistir isso". A mulher gosta muito de assistir novela. E aí a gente vai e não pega na sanfona. Mas antigamente todo final de semana tocava sanfona. Quando não era em forró era em casa. Não tinha música, então, pegava na sanfona. Pegava, mexia muito na hora de dormir. Mas hoje em dia já não facilita. Às vezes está ali, a casa é uma só: “Ah, fulano vai tocar sanfona, vai empatar eu de assistir meu filme, assistir minha novela". Deixa pra lá, deixa eles assistirem novela, não vou pegar sanfona não. 
$\mathrm{P} / 1$ : Mas antigamente não tinha televisão, não tinha luz elétrica.

R: Antigamente nem rádio tinha, que dirá a televisão. Naquele tempo que a gente aprendia nem rádio conhecia lá. Aí começou a aparecer o rádio, daí a pouco tinha aquela radiola que tinha aqueles discos grandes, que foi aparecendo. Daí a pouco eu fui esquecendo de sanfona, de violão, viola, essas coisas. Às vezes estava dentro de casa, os filhos, a mulher: "Quero assistir uma coisa, se for tocar sanfona eu vou empacar, que eu vou zoar e atrapalhar". Então, por causa disso, deixa eles assistirem, deixa a sanfona pra outra hora. Na hora que eles saírem pra fora eu pego a minha sanfona. Antigamente não tinha essas coisas, tinha que escutar era sanfona mesmo. Se não tem opção, então a gente tinha que escutar o som da sanfona. Agora demora mais de tocar sanfona. Aqui também, toda semana eu tocava sanfona.

P/1: Seu Aurino o senhor tem feito caminhada com o Márcio nas escolas, nas comunidades?

R: Já fiz.

$\mathrm{P} / 1$ : Descreve como é que é uma caminhada como mestre griô?

$\mathrm{R}$ : Ah, a gente tem que sair às vezes. Quando era lá mesmo a gente ia nas escolas fazendo visita, fazia alguma apresentação cantando, tocando alguma coisa que fosse possível. Nessas reuniões é comum: "Vamos cantar isso, vamos fazer isso, vamos cantar tal coisa". Então nós vamos ali apresentar na escola de fulano, na casa de fulano, lá mesmo no Remanso, fazia um show lá. Eu já estou lá, moro lá. Então lá a gente saía nas escolas, fomos apresentar lá, eu estava junto com eles, cantando, tocando sanfona, cantando as músicas, dançando.

$\mathrm{P} / 1$ : Mas qual é a importância de ter uma caminhada assim?

$\mathrm{R}$ : Eu gosto muito de fazer caminhada porque a caminhada faz muitas coisas pra gente. A gente faz várias coisas, a gente se diverte, a gente puxa a memória da gente pra alguma coisa que está esquecida. Por isso a importância da caminhada é esse tipo de coisa. Então é muito importante pra mim.

$\mathrm{P} / 1$ : E como é que o mestre griô é recebido nas casas nessas caminhadas?

R: A gente é bem recebido. Aonde eu tenho andado com eles nunca fui mal recebido. Aonde eu tenho ido com eles é sempre bem recebido pelo pessoal da terra.

$\mathrm{P} / 1$ : Canta junto? 
R: Canta junto as meninas, o pessoal, professor, todo mundo está junto. É muito alegre, eu sempre gosto de fazer caminhada com a turma. Eu gosto muito da alegria. A alegria faz parte da saúde da gente.

$\mathrm{P} / 1$ : E agora que o senhor está aposentado e é o mestre griô, qual que é a importância de estar participando desses encontros da Ação Griô, encontrando outros mestres?

R: A importância pra mim é isso. É como eu lhe falei mais uma vez, é mais amizade e mais aquele prazer e mais conhecimento que estou encontrando e quero encontrar mais. A importância pra mim é, além de eu estar fazendo alguma coisa, estar fazendo algum trabalho, estou encontrando amizade e conhecimento, e depois disso conhecendo lugares também, que tem muito lugar que eu não conheço. Mais eu vou conhecendo, mais eu vou tendo amizades.

P/1: No encontro aqui da Serra do Cipó, o que o senhor mais gostou daqui, nesses quatro dias que a gente está aqui?

R: Eu gostei muito, eu gostei de todas as coisas. Eu gostei muito da união, porque nos outros lugares sempre tem união, mas eu acho que aqui foi mais um pouco. Todo lugar que a gente anda tem união, mas aqui eu achei que foi mais um pouco do que os outros lugares. Além de ser mais um pouco, tem o tipo do lugar, é sossegado, é muito tranqüilo. Parece que o povo daqui já conhecia a gente antes da gente chegar, e todo mundo chama a gente pelo nome, vai vendo e conhecendo. Tem hora que eu vou passando aqui, o pessoal: "Oh mestre, oh mestre”, e eu não sei quem é. Então pra mim é importante. Uma coisa que eu achei ótimo aqui foi isso, o rol de conhecimento e o rol de atenção à gente, muita atenção pra gente. Tanto faz novos como velhos, os mais velhos. Eu gostei muito, é muito importante.

$\mathrm{P} / 1$ : $\mathrm{E}$ assim, pra gente acabar as perguntas e pegar lá a sanfona, o quê que o senhor achou de ter ficado aqui com a gente agora, ter dado a entrevista, ter contado a história do senhor, da infância, adolescência? O quê que o senhor achou?

R: Eu achei importante porque pra mim é uma grande coisa. Talvez, quem sabe, amanhã o povo não vai saber: "Você estava proseando lá, eu vi". Que nem lá, eu fiz uma entrevista com o pessoal aí, o povo dá notícia. Esses dias mesmo eu fui dar uma entrevista lá mesmo no Remanso. Aí eles mandaram pra modo de sair na Record, pra gente escutar no horário e coisa e tal. Parece que foi um negócio. Eu nunca assisti, e lá o povo dando notícia: “Olha, ele passou na Record, não foi?”. O povo em Lençóis tudo dando notícia. Eu nunca assisti. Eles mandaram, eu já liguei a TV no horário que eles falaram pra eu entrar e nunca aconteceu. Parece que o dia que eu vou ligar pra assistir é que não acontece. O dia que eu não vou o povo dá notícia. É isso, pra 
mim a importância é isso. Mais a gente vai crescendo, mais vai ficando reconhecido, o pessoal do lugar que não conhece. Os que conhecem sabem que a gente fez aquela entrevista, sabe que o povo está conhecendo a gente. Quem não conhece não vai lá fazer essa entrevista, quem nunca viu, né? Então sabe que a gente proseou, teve aquela prosa com esse pessoal, ainda um jornalista, que é uma grande pessoa.

\section{P/1: Imagina.}

R: Então pra mim o interesse é ótimo eu fazer essa entrevista, me interesso.

$\mathrm{P} / 1$ : O senhor acha que ficou faltando perguntar alguma coisa ou falar de alguma coisa que eu não perguntei?

R: Que está na minha lembrança por enquanto não. A minha lembrança antiga não deixa de ficar alguma coisa esquecida porque é muitas coisas, é difícil a gente lembrar toda a vida assim do princípio ao fim. Com certeza fica coisa. Depois que passa que a gente: "Ah, tinha coisa de fulano que eu poderia ter falado e eu esqueci". Mas isso sempre tem. Acho que não tem esse pra modo de não deixar uma coisinhas pra trás, aquelas coisinhas mais velhas, aquela lembrançazinha, aquelas coisas mais cedo, que passa anos que já fizemos.

$\mathrm{P} / 1$ : Mas o que o senhor recordou aqui foi importante pro senhor?

R: Foi importante. Foi importante que foi uma vivência. O que eu sobrevivi, as coisas que eu sobrevivi até agora, estou sobrevivendo também. Então foi importante a gente lembrar das coisas, do que é bom, o que é bom pra gente, o que faz a gente ser feliz. É importante a gente estar lembrando, a gente estar falando. É muito importante.

$\mathrm{P} / 1$ : Eu queria agradecer o senhor ter ajudado a gente, ter feito a entrevista. Eu queria agradecer.

R: Que nada. Pra mim eu estou muito prazeirado. Eu muito agradeço a vocês também, de participar dessa entrevista. 